\title{
The East Is Real: Orientalism and Its Enemies
}

\author{
Without failure, there can be no ethics. \\ Pour une morale de l'ambiguité. ${ }^{1}$

\begin{abstract}
Without investigation there is no right to speak.
\end{abstract} \\ Chairman $\mathrm{Mao}^{2}$
}

The wise man changes his mind; the fool never does.

Greek Proverb

Algeria without Apology

When Fanon and Beauvoir met in 1961, they didn't, as far we know, discuss whether there should have been footnotes to The Second Sex in the book he'd published nine years earlier. Did they talk at all about the "position of women" in France's colonies, or in the Algerian revolution, or more generally? Beauvoir does not record any such conversation, either, in the vivid and moving pages of La force des choses she devoted to Fanon's meeting with Sartre, Claude Lanzmann, and herself. ${ }^{3}$ Nor, apparently, did they pursue, as Sabine Broeck would have wished, "a philosophical questioning of the white premises of the Enlightenment": Broeck is correct that "a concerted epistemically programmatic critique did not emerge."

There were other things to talk about in 1961. Colonialism in Algeria and throughout Africa was taking a long and bloody time to die, and the prospects for what would follow it were not encouraging. Lanzmann (who met Fanon first) reported him as devastated by the assassination of Patrice Lumumba, and also by the mounting evidence of fractures and fault lines to African unity,

1 “[S]ans échec, pas de morale" (Pour une morale de l'Ambiguïté [hereinafter PMA ], 14, Ethics of Ambiguity [hereinafter $E A]$, 10).

2 Mao Zedong, "Reform Our Study," 23.

3 La Force des Choses (hereinafter FCh), 2:420-27, 439-41; Force of Circumstance (hereinafter FCirc), 605-611, 620-21.

4 Sabine Broeck, "Re-reading de Beauvoir After Race," 170. See chapter 3 above. 
his most urgent commitment. ${ }^{5}$ When the four came together in Rome, Fanon was worried that France was about to invade Tunisia, and watching his own back vigilantly: assassins had already made at least one attempt to take his life. The metropole too seemed on the brink of civil war. Sartre's apartment had just been bombed, for the second time, in reprisal for his support of the Algerian revolution and his denunciation of torture by French forces there. Fanon himself was dying of leukemia. It can hardly have seemed like the moment for querying the episteme.

Interestingly, the conflict over Algeria brought together intellectuals whose epistemological commitments were quite diverse. The 1960 Manifesto of the 121 against the Algerian war ("Déclaration sur le droit à l'insoumission dans la guerre d'Algérie"), signed by Beauvoir and Sartre and many others (but not by Camus), was originally drafted by Maurice Blanchot, who might reasonably be considered the grandfather of deconstruction. As Gisèle Sapiro showed for the question of collaboration with Vichy, epistemological commitments are poor predictors of political ones. ${ }^{6}$

What Beauvoir and Fanon did talk about included Fanon's formation as a revolutionary leader. She gives a very compelling and nuanced account of how his experiences of racism in France and in Algeria moved him from assimilationist optimism to militant advocacy of direct action. Everything he wrote against intellectuals he wrote against himself, she says, explaining how his lived experience of racism as a student had called into question the humanist abstractions with which he, like Sartre and herself, had been raised as a French subject. ${ }^{7}$ And they talked about the future, about the difficulties facing panAfricanism given the cultural differences and divisions between and among peoples of color, which were confirming the complex account of Black identity Fanon gave in Peau noire masques blancs.

But in the end, what Beauvoir and Fanon most had in common was a war. Both were passionately engaged in a real-world struggle for third-world

5 FCh 2:408, FCirc 597. Patrice Lumumba, the first democratically elected prime minister of the Congo, was assassinated on January 17, 1961, apparently with the complicity of the CIA: Cold War machinations were deeply entangled with post-independence infighting between Congolese factions. In May, Les Temps Modernes had published a long section from what became Les damnés de la terre, for which Sartre would write the famous preface; extracts from L'an $V$ de la révolution algérienne (usually translated as A Dying Colonialism) had appeared there in May-June 1959.

6 Sapiro, La guerre des écrivains.

7 FCh 2:424, FCirc 6og. Unlike some later commentators, Beauvoir does not seem to see a sharp break between Peau noire masques blancs and Les damnés de la terre, between the philosopher-psychologist and the professional revolutionary responsible for training troops. 
liberation, each on the basis, not of a theoretical critique or a fantasized identification, but of a lucid understanding of their actual, and very different, social locations in a concrete world: a world that, to steal Yeats's phrase, was changing minute by minute.

Or perhaps there was an epistemic critique, in a way, in the basic sense of an acknowledgement that what you see and know is conditioned by where you are placed to see it. Throughout La force des choses Beauvoir very much situates herself as French, and as French at that moment of danger, rather than assuming the "view from nowhere" of ahistorical universalist humanism; she speaks of the shame of being French in terms very similar to those of L'Amérique au jour le jour 1947, when her color "burned her." And as in the earlier book, she gives a detailed and devastating account of her reasons.

The sky was so blue that as I sat facing my open window I wanted to write just for the sake of writing, as I would have sung just to sing, if I'd had any voice. "I've got some things to show you," Lanzmann said one evening. He took me to dinner outside Paris, in a sleepy fragrant country village, and suddenly, hell was back on earth. Marie-Claude Radziewski had given him a file which contained accounts of the treatment inflicted by the harkis, in the cellars of the Goutte d'Or, on Moslems handed over to them by the DST: electrodes, burning, impaling on bottles, hangings, stranglings. The tortures were psychological as well as physical. Lanzmann wrote an article on the subject for Les Temps Modernes and published the dossier of charges. A student told me that she had been in the street near the Goutte d'Or and seen bleeding men dragged house to house by the harkis. Every night the neighbors heard their screams. "Why? Why? Why?" The unendingly repeated cry of a fifteen-year-old Algerian boy who had watched his whole family being tortured ripped at my eardrums and my throat. Oh, how mild they had been in comparison, those abstract storms of revolt I had once felt against the human condition and the idea of death! ... [A]t least then my horror had been directed at something outside myself. Now I had become an object of horror in my own eyes. ${ }^{8}$

8 The Goutte d'Or quarter of Paris was and is home to African migrants and their working-class descendants; DST stands for "Direction de la Surveillance du Territoire," an arm of the police force responsible for domestic surveillance and counter-espionage. Analogous to the CIA in the United States, it behaved comparably during this period, including arming a group responsible for "false flag" attacks and other delightful behavior. See Jim House, "Colonial and Post-Colonial Dimensions of Algerian Migration to France."

"Le ciel était si bleu que, face à la fenêtre ouverte, j’avais envie d'écrire, pour ne rien dire, comme j'aurais chanté si j'avais eu de la voix. 'J'ai des choses à te montrer', me dit Lanzmann 
At an early stage, she notes, "It seemed to us that the [French] Left had nothing to teach the Algerians, and that ElMoudjahid was quite right to put them in their place"9-an echo of Leiris's point: Africa does not need me. But the tortures described above took place in Paris. And "France" itself was becoming unrecognizable. ${ }^{10}$ By the time of the meeting with Fanon, to be "French" meant to be inescapably responsible for violence undertaken "in one's name," violence one is helpless to prevent, but in which one is nonetheless implicated.

In a fine article, Annabelle Golay has done a very thorough job of putting Fanon's later writing (L'an $V$ de la révolution algérienne and Les damnés de la terre) in dialogue with Beauvoir's activism as described, over hundreds of pages, in the second volume of Laforce des choses, which Golay shows as very much part of the same project. .1 Golay doesn't use the word "activism," which seems to have no exact French equivalent. What do I mean by it? nothing especially glamorous: meetings, mostly. Now and again a demonstration. Writing editorials and pieces for Les Temps Modernes, soliciting and editing articles from others. Taking public stands in the hope of changing minds; when she can't, continuing the work of testimony and documentation.

un soir. Il m'emmena dîner aux environs de Paris, dans un village endormi qui sentait la campagne; et soudain, l'enfer remonta sur la terre. Marie-Claude Radziewski lui avait communiqué un dossier sur les traitements infligés par les harkis, dans les caves de la Goutte-d'Or, à des Musulmans que leur livrait la DST: gégène, brûlures, empalements sur des bouteilles, pendaisons, étranglements. Les tortures étaient entrecoupées d'actions psychologiques. Lanzmann écrivit là-dessus un article pour Les Temps Modernes et publia le dossier des plaintes. Une étudiante me raconta qu'elle avait vu de ses yeux, rue de la Goutte-d'Or, des hommes en sang que des harkis traînaient d'une maison à une autre. Les gens du quartier entendaient toutes les nuits des hurlements. 'Pourquoi? Pourquoi? Pourquoi?': ce cri indéfiniment répété d'un petit Algérien de quinze ans qui avait vu torturer toute sa famille me déchirait les tympans et la gorge. Qu'elles étaient bénignes les révoltes où me jetaient jadis la condition humaine et l'idée abstraite de la mort! ... Et du moins le scandale demeurait hors de moi. Aujourd'hui j'étais devenue scandale à mes propres yeux" (FCh 2:409-10, FCirc 598).

9 'Nous trouvions que la gauche n'avait pas de leçon à donner aux Algériens et qu'El Moudjahid avait bien fait de le remettre à sa place" (FCh 2:127, FCirc 381). The articles in El Moudjahid to which she refers were probably largely authored by Fanon himself.

" $[\mathrm{P}]$ ointing to the flowering apple orchards, Lanzmann said in a desolate voice: 'Even the grass won't be the same color any more.' What devastated us was to suddenly discover the face of France as it had become, little by little, depoliticized, inert, ready to give itself over to the men who wanted to continue the war to the point of atrocity." [Me montrant les clos fleuris de pommiers, il me dit d'une voix désolée: "Même l'herbe n'aura plus la même couleur." Ce qui nous accablait c'était de découvrir soudain le visage qu'avait pris peu à peu la France: dépolitisée, inerte, prête à s'abandonner aux hommes qui voulaient poursuivre à outrance la guerre (FCh 2:152; FCirc 404, translation altered).] 
Should I be calling this activism? Beauvoir herself does not. In La force des choses and elsewhere, she contrasts herself to her friend Francis Jeanson, who put his life on the line by helping to deliver weapons to the FLN, and her former student Jacqueline Guerroudj, who participated in the Battle of Algiers and was condemned to the guillotine for her militant activities. Beauvoir told Madeleine Gobeil: "I felt and thought about things in a political way, but I never engaged in political action." ${ }^{12}$ La force des choses:

Since the Left had completely failed in its attempt to carry on the struggle within the limits of legality, if one wanted to remain faithful to one's anticolonialist convictions and free oneself of all complicity with this war, then underground action remained the only course. I admired those who took part in such action. But to do so demanded total commitment, and it would have been cheating to pretend I am capable of such a thing. I am not a woman of action; my reason for living is writing; to sacrifice that I would have to believe myself indispensable in some other field. Such was not by any means the case. I contented myself with giving what help I could when I was asked for it; certain of my friends did more. ${ }^{13}$

Whatever we want to call it, Beauvoir's testimony on behalf of Jacqueline Guerroudj is often credited as decisive in winning her reprieve. Beauvoir and

12 "The Art of Fiction No. 35," interview with Madeleine Gobeil, 35. Sonia Kruks comments on this point: "As a well-known public figure, who by this time could not sit in a café without being recognized, [Beauvoir] was not practically speaking a good bet for underground activity. She was far too visible easily to shelter FLN militants, to transport money or materials for them, as the 'Jeanson network' and others were doing.... In fact, Beauvoir did at times offer practical support to the network: she lent members her car and allowed her apartment to be used. On at least one occasion, she helped to find a secure hiding place for a fugitive" (Kruks, "Politics of Privilege," 202). Kruks cites Hervé Hamon and Patrick Rotman, Les porteurs de valises, 158 and 283 . She also notes that "under the emergency powers of the time," actions such as signing manifestos and attending banned demonstrations were "acts of illegality," and that after the publication of Djamila Boupacha (which Beauvoir co-signed with Gisèle Halimi) a death threat was telephoned to Beauvoir's apartment.

13 "La gauche ayant échoué à mener dans la légalité un combat efficace, si on voulait rester fidèle à ses convictions anticolonialistes et briser toute complicité avec cette guerre, il ne restait d'autre issue que l'action clandestine. J'admirais ceux qui la menaient. Seulement elle exigeait un engagement total et ç'aurait été tricher que de m'en prétendre capable: je ne suis pas une femme d'action; ma raison de vivre, c'est d'écrire; pour la sacrifier, il aurait fallu me croire ailleurs indispensable. Ce n'était pas du tout le cas. Je me contentai de rendre, quand on me le demanda, des services; certains de mes amis firent d'avantage" (FCh 2:245-56, FCirc 472). 
Sartre had signed the Manifesto of the 121, the "Déclaration sur le droit à l'insoumission dans la guerre d'Algérie." Les Temps Modernes had vigorously sponsored Henri Alleg's book, La question, which described his torture by French troops (and was banned by the French government); a letter of defiant support from Sartre had been read out at the trial of Jeanson's underground network. As a result, it had been unsafe, for a time, for Sartre and Beauvoir to be in France. Even after they returned, Paris felt to Beauvoir like an occupied city. Her own government's support of torture and massacre, police brutality and censorship, the casual racism of the people in the streets, the deceitful lies of the government and the mainstream press poisoned everyday life and saturated her with shame. "I had been called an enemy of France: I became one."

This hypocrisy, this indifference, this country, my own self, were no longer bearable to me. All those people in the streets, in open agreement or battered into a stupid submission - they were all murderers, all guilty. Myself as well. "I'm French." The words scalded my throat like an admission of hideous deformity. For millions of men and women, old men and children, I was one of the people who were torturing them, burning them, machine-gunning them, slashing their throats, starving them; I deserved their hatred because I could still sleep, write, enjoy a walk or a book.... I felt that I was suffering from one of those diseases whose most serious symptom was the absence of pain. ${ }^{14}$

Other commentators on Beauvoir's work at this period have highlighted her work on behalf of Djamila Boupacha, whose shameful treatment-falsely accused of setting a bomb, she was raped and tortured by French forces, with the complicity of higher-ups-Beauvoir denounced in Le Monde; Beauvoir headed up the committee of support, and accompanied Gisèle Halimi in interviewing French officials, whose disgraceful statements and behavior they detailed in a

14 "Je ne supportais plus cette hypocrisie, cette indifférence, ce pays, ma propre peau. Ces gens dans les rues, consentants ou étourdis, c'étaient des bourreaux d'Arabes: tous coupables. Et moi aussi. 'Je suis française.' Ces mots m'écorchaient la gorge comme l'aveu d'une tare. Pour des millions d'hommes et de femmes, de vieillards et d'enfants, j'étais la sœur des tortionnaires, des incendiaires, des ratisseurs, des égorgeurs, des affameurs; je méritais leur haine puisque je pouvais dormir, écrire, profiter d'une promenade ou d'un livre: les seuls moments où je n'avais pas honte, c'étaient ceux où je ne le pouvais pas.... Il me semblait traîner une de ces maladies où le symptôme le plus grave, c'est l'absence de douleur" (FCh 2:145, FCirc 396-97). 
book. ${ }^{15}$ Dramatic as this was, I see it not as an isolated incident, but rather as embedded in the day in day out of resistance, resistance as a way of life.

As usual, I feel that summary can't do justice to the texture of Beauvoir's narration, which catches us up in the alternations of hope and despair. Perhaps her most important activism was this work of testimony, as the period documented in La force des choses catches up to its own moment of writing. ${ }^{16}$ She documents it all, in detail, move by move: massacres, tortures and disappearances, Muslims rounded up in the Vel' d'Hiv where the Jews had been held, systematic rapes in detention camps. Listening to the radio with Michel and Zette Leiris, just as she and Sartre had done during the Second World War. ${ }^{17}$ At one point she turns to reproducing pages from her diary, as she'd done in the part of La force de l'âge that covers the worst days of the Occupation; what horrible thing did we just learn about, how did other people react.... As the rules of human rights are suspended not just in Algeria but in France itself (censorship, bans, firings, deportations), she draws parallels with the Nazis, with the massacre at Oradour and the rounding-up of French Jews. ${ }^{18}$ She describes also a progression of her awareness and shame about being French, how she walks around gritting her teeth as French people say stupider and stupider things and show unconcern in the face of casual brutality against Algerians and then against demonstrators. ${ }^{19}$ La force des choses also records travel—Cuba, Brazil,

15 FCh 2:298-306, 402, 436, 449; FCirc 513-18, 591-92, 618, 628. While most of Djamila Boupacha was written by Halimi, Beauvoir's name was given as author so that she could take responsibility if a prosecution resulted, which seemed quite likely. See also Kruks, "Politics of Privilege," Mary Caputi, "Simone de Beauvoir and the Case of Djamila Boupacha," Karen Shelby, "Beauvoir and Ethical Responsibility," and Julien Murphy, "Beauvoir and the Algerian War: Toward a Postcolonial Ethics." See now also Lori Marso, "Politics with Beauvoir," 94-120.

16 See also Ursula Tidd, Gender and Testimony, especially chapter 6.

17 FCh 2:256, FCirc 404.

18 "Ten thousand Algerians have been herded into the Vel' d'Hiv, like the Jews at Drancy once before. Again I loathed it all—this country, myself, the whole world." [Dix mille Algériens étaient parqués au Vel' d'Hiv, comme autrefois les Juifs à Drancy (FCh 2:431, FCirc 614).]

19 For instance: “Yes, the poor Germans—one realizes now it wasn't their fault." [Oui, pauvres Allemands: on se rend compte maintenant que ce n'était pas de leur faute (FCh 2:455, FCirc 633).] Beauvoir says that "[f]rom then on, having a coffee at the bar or going to the boulangerie was a trial. You heard people say that 'the whole thing was the Americans wanting our oil,' or, 'why are we waiting? One good blow will finish it.' ... I had liked crowds. Now even the streets were hostile, and I felt as dispossessed as in the first days of the occupation." [Désormais, boire un café à un zinc, entrer dans une boulangerie, ce fut une épreuve. On entendait: “Tout ça, c'est les Américains qui veulent notre pétrole." Ou bien: "Qu'est-ce qu'on attend pour en mettre un bon coup et en finir?" ... J'avais aimé les foules: maintenant même les rues m'étaient hostiles, je me sentais aussi dépossédée qu'aux premiers temps de l'occupation (FCh 2:125, FCirc 381).] 
China (more on this below), Africa, the Soviet Union - which took place within the context of support for revolutionary movements, respites of optimism against a backdrop of dread. Going to a demonstration, being moved by a sense of solidarity, and yet coming home to futility and rage: if only there had been more of us, if only the unions had come out earlier, if only the Communists hadn't bailed on us (again).... And she talks about a "tetanus of the imagination" resulting from wave after wave of bad news, atrocities, massacres, torture and rapes, suspensions of the rule of law. The worst thing, she says, "is that you get used to it." 20

Working through this in the first year of Donald Trump's administration, what resonated most for me was her description of walking that difficult line. How to avoid defeatism ("demonstrations never change anything") without grandstanding, without exaggerating the importance of what one says or does; how to mark one's own visceral responses without narcissism or selfcomplacency. ${ }^{21}$ I remember Anne in Les mandarins, finding it hard to answer Scriassine's questions about life in Paris under the Occupation: "the truly awful

20 "Today, in this grim December of 1961, like most of my fellow-creatures I suppose, I am suffering from a sort of tetanus of the imagination. [Here she quotes details of torture from trial testimony.] I read this and move on to another article. That, perhaps, is the final stage of demoralization for a nation: one get used to it." [Aujourd'hui, en ce sinistre mois de décembre 1961, comme beaucoup de mes semblables, je suppose, je souffre d'une sorte de tétanos de l'imagination.... C'est peut-être ça le fond de la démoralisation pour une nation: on s'habitue (FCh 2:122, FCirc 379).] Very similar language occurs in "Pour Djamila Boupacha," which appeared in Le Monde, and in the introduction to Djamila Boupacha.

21 One is entitled to one's very own despair and self-loathing; one is not entitled to infect others with it under the guise of political analysis, much less "theory." And one must live through these things in one's own skin, without mistaking one's inner theatre of war for the actual ongoing struggle. "When one lives in an unjust world there is no use hoping by some means to purify oneself of that injustice; the only solution would be to change the world, and I don't have that power. To suffer from these contradictions serves no good purpose; to blind oneself to them is mere self-deception. [Quand on habite un monde injuste, inutile d'espérer, par aucun procédé, se purifier de l'injustice; ce qu'il faudrait, c'est changer le monde et je n'en ai pas le pouvoir. Souffrir de ces contradictions, ça ne sert à rien; les oublier, c'est se mentir (FCh 2:501, FCirc 668-69).]

But see also Ursula Tidd, Gender and Testimony (1999): "Although presence is sometimes all that is possible in our relationship with the Other, Beauvoir represents her project of testimonial autobiography as a means of reaching these others whose testimonies are silenced in order to break down our common existential isolation. Living with others in 'the real,' resisting the Disneyland hyperreality parodied by Beauvoir in the mid-sixties in Les belles images, may seem an increasingly remote option at the end of the second millennium. Before we learn to live with the 'loss of the real' [the reference is to Baudrillard, Simulacres et simulations], Beauvoir's testimonial autobiographical project alerts us to the continuing importance of being there and bearing witness" (154). 
things, it wasn't me they happened to; and yet they haunted my life."22 Later Beauvoir would say to Madeleine Gobeil, "everyone has forgotten about Algeria"; ${ }^{23}$ she'd go on to dramatize this French amnesia in Les belles images (1966). At our own moment in particular, it seems important not to reproduce that amnesia in scholarship on Beauvoir, not to act as if "nothing happened" between The Second Sex and the 1970s.

Golay also points out that the solidarity between Beauvoir and Fanon at the time of their meeting did not come out of nowhere.

The story of their meeting, as told in La force des choses (1963), makes it possible to think about the common stakes for oppressed nations and oppressed individuals, women and colonized peoples, and to establish the unifying link between French feminism and the call for decolonialization. Woman's alterity with respect to man is comparable to that of the colonized with respect to the colonizer. Beauvoir highlights this parallel from the first pages of The Second Sex. The essay should be reread,

“[L]es vrais malheurs ce n'est pas à moi qu'ils étaient arrivés, et pourtant ils avaient hanté ma vie" (Les mandarins, 1:111).

23 "De Beauvoir: I felt and thought about things in a political way, but I never engaged in political action. The entire last part of Force of Circumstance deals with the war. And it seems anachronistic in a France which is no longer concerned with that war.

Interviewer: Did you realize that people were bound to forget about it?

De Beauvoir: I deleted lots of pages from that section. I therefore realized that it would be anachronistic. On the other hand, I absolutely wanted to talk about it, and I'm amazed that people have forgotten it to such a degree. Have you seen the film La Belle Vie, by the young director Robert Enrico? People are stupefied because the film shows the Algerian war. Claude Mauriac wrote in Le Figaro littéraire: 'Why is it that we're shown parachute troopers on public squares. It's not true to life.' But it is true to life. I used to see them every day from Sartre's window at Saint-Germain-des-Prés. People have forgotten. They wanted to forget. They wanted to forget their memories. That's the reason why, contrary to what I expected, I wasn't attacked for what I said about the Algerian war but for what I said about old age and death. As regards the Algerian war, all Frenchmen are now convinced that it never took place, that nobody was tortured, that insofar as there was torture they were always against torture" ("The Art of Fiction No. 35," interview with Madeleine Gobeil, $35^{-6) \text {. }}$

In the 1986 interview with Hélène Wenzel for Yale French Studies, Beauvoir indicated at the outset that she had written about "other things," not just feminism: "As a result, I'd prefer that a focus on my writing and my work not be absolutely limited ... to the woman question" (Wenzel, "Interview with Simone de Beauvoir," 6). But she was unsuccessful in getting Wenzel to discuss those "other things," and the articles in the issue (an important breakthrough for Beauvoir scholarship in the United States) focused entirely on feminist questions. 
in this respect, starting from the situation of its writing and the colonial context. $^{24}$

That last sentence describes what I've been trying to do right along. I'd add that, while Laforce des choses describes her relationship to France and Frenchness as changing during the Algerian conflict, her disgust, and her awareness of linkage between social conservatism and the war machine, had been wellprepared by her previous intellectual commitments: remember the refusal of knee-jerk nationalism at the heart of her conception of the One and the Other, and her uptake of the surrealist response to Claudel's smug patriotism. ${ }^{25}$ As is true for Fanon, there is more ethical and political continuity throughout the development of her work than may at first appear.

I agree with Golay, too, in not seeing any contradiction between drawing a parallel between two sorts of oppressions, and being deeply committed to ending both of them, whether together or separately. (As I write that, I am asking myself, why would anybody think that would be a contradiction? Was I fighting a straw person, for all those pages?) Golay goes so far as to say that for Beauvoir, the struggle against racist colonialism took precedence over the lutte des femmes during the years chronicled in La force des choses, and I think she's right.

It's not that Beauvoir forgets about women during the second volume of $L a$ force des choses. She notes casual points of interest, for instance, that Castro's guerilla army included some women, "a fact which caused a good many sniggers among the French bourgeoisie"; 26 that "six women prisoners in the La Roquette prison escaped; a pretty feat, well-organized, and one that should

24 "Le récit de leur rencontre dans La force des choses (1963), permet de penser les enjeux communs aux nations et aux individus opprimés, femmes et colonisés, et d'établir le lien qui unit le féminisme français et les revendications de la décolonisation. L'altérité de la femme par rapport à l'homme est comparable à celle du colonisé par rapport au colon. Beauvoir met en lumière ce parallèle dès les premières pages du Deuxième sexe (1949). L'essai doit être relu, à cet égard, à partir de sa situation d'écriture et du contexte colonial" (Golay, "Féminisme et postcolonialisme," 408).

25 In the course of one demonstration, in 1957, we run into our old friend Adamov: "There were cries of 'Down with de Gaulle,' shouted out syllable by syllable as though we were at a sporting event, and Adamov said angrily, 'It's all too gay, this isn't how we should be behaving." [On a crié "À bas de Gaulle" au rythme des monômes d'étudiants et Adamov a dit avec irritation: "C'est trop gai, ça ne convient pas" (FCh 2:217, FCirc 451).] He's still criticizing style, but (throughout La force des choses) he's still by their side, along with Leiris and a number of other veterans of surrealism (Tzara, Masson...).

26 "Dans la petite armée qui tenait le maquis avec lui, il y avait des femmes, ce qui suscitait chez les bourgeois français des rires égrillards" (FCh 2:137-38, FCirc 391). 
have been a help to all women in getting rid of their inferiority complexes." 27 She also makes brief mentions here and there of what would later be labelled "sexism." For instance, when describing her disappointment with the increasing conservatism of Dos Passos and with Faulkner's failure to disavow his racist Southern heritage, she also rethinks her admiration for Hemingway, noting the anti-Semitic tinge of The Sun Also Rises: "Aryan, male, endowed with wealth and leisure-[Hemingway] speaks as one seigneur to the other." ${ }^{28}$ She expresses admiration for younger women she meets: the mixed-race Chinese writer Han Suyin; ${ }^{29}$ the Algerian lawyer Gisèle Halimi, who enlisted her support for Djamila Boupacha; ${ }^{30}$ the young working-class novelist Christiane Rochefort. ${ }^{31}$ She is gratified by the reception of The Second Sex in America, its "success

27 "Six détenues de la Roquette s'évadèrent; un joli exploit, bien machiné et qui aurait dû aider les femmes à se nettoyer de leurs complexes d'infériorité" (FCh 2:409, FCirc 597-98).

28 'D'ailleurs, les complicités que nous propose Hemingway à tous les tournants de ses récits impliquent que nous avons conscience d'être, comme lui, aryens, mâles, dotés de fortune et de loisirs, n'ayant jamais éprouvé notre corps que sous la figure du sexe et de la mort. Un seigneur s'adresse à des seigneurs. La bonhomie du style peut tromper, mais ce n'est pas un hasard si la droite lui a tressé de luxuriantes couronnes: il a peint et exalté le monde des privilégiés" (FCh 2:132, FCirc 386-87).

See also "The Art of Fiction No. 35," interview with Madeleine Gobeil, 34, where they discuss Hemingway as a paradigmatic uncommitted writer.

FCh 2:231, FCirc 461-62.

$30 \quad$ FCh 2:225, FCirc 457 .

31 "[Rochefort's Les petits enfants du siècle] had caused less of a scandal than her first [book], but she'd had another cartload of self-righteous filth emptied on top of her all the same. 'It's happened to me too,' I told her. 'It must have been worse for you, though,' she said sympathetically, 'because I'm a tramp anyway, you know.' And indeed, I was always conscious of my middle-class origins when I was with her; she was a real working-class girl, and there wasn't much she hadn't seen: I envied her daring, her fire, her inner freedom. For the time being, she wasn't writing. 'I can't get interested in my piddling little stories, not at the moment!'

I understood how she felt. The assassination of Lumumba, the last pictures of him, the photographs of his wife leading his mourners, head shaved, breast bare-what novel could compete with that?"

[Ce livre avait moins scandalisé que le premier, mais tout de même on l'avait à nouveau aspergé de vertueuse merde. "J'ai connu ça, lui dis-je. —Ça a dû être plus gênant pour vous, ma-t-elle dit avec sympathie, parce que moi, je suis une truande." Près d'elle en effet, j'avais conscience de mes origines bourgeoises; c'était une fille du peuple et elle en avait vu de toutes les couleurs; elle avait des audaces, une verve, une liberté que je lui enviais. Pour l'instant, elle n'écrivait pas: “Je ne peux pas m'intéresser à mes petites histoires, en ce moment!"

Je la comprenais. L'assassinat de Lumumba, les dernières images qu'on vit de lui, les photographies de sa femme menant le deuil tête rasée, seins nu, à côté de ça quel roman pouvait tenir le coup? (FCh 2:407, FCirc 596).] 
unspoiled by any salacious comment,"32 and also gratified by those who write to thank her for it, and to provide more evidence that "[i]t's terrible to be a woman"; their letters, she says, would make a moving document. "I wasn't wrong when I wrote The Second Sex, in fact I was even more right than I knew at the time." ${ }^{33}$ As she reads page proofs for Mémoires d'une jeune fille rangée, she says she hopes it will help younger women; ${ }^{34}$ and she even gives several feminist talks.

But her heart does not seem to be in it. "At the university [of Rio de Janeiro] I spoke - not because I wanted to, but because I had been asked-on the position of women." ${ }^{35}$ Describing another such talk in São Paolo she says,

Once more I found myself talking about women in a large flower-decked and scented hall, addressing a lot of bedizened ladies who were thinking exactly the opposite of what I was saying; but a young woman lawyer thanked me on behalf of women who work. ${ }^{36}$

Most of these women seem to have all too much in common with the French "society women who listen in ecstasy" to the sickeningly patriotic and

32 "Le deuxième sexe parut en Amérique avec un succès que ne salit aucune chiennerie. J'y tenais à ce livre et j'ai été contente de vérifier-chaque fois qu'on l'a publié à l'étrangerqu'il avait fait scandale en France par la faute de mes lecteurs, non par la mienne" (FCh 2:19, FCirc 298).

33 “Que de correspondantes me répètent: 'C'est terrible d'être une femme!' Non, je ne me trompais pas en écrivant Le deuxième sexe, j'avais même encore plus raison que je ne le pensais. Avec des extraits de lettres reçues depuis ce livre, on aurait un document navrant" (FCh 2:188, FCirc 429).

34 "[F]or once, one of my books is giving me pleasure to reread. Unless I am mistaken, it should be a success with young girls who are having problems with their family and religion and who do not yet dare to dare." [Hier après-midi, j'ai corrigé un énorme paquet d'épreuves envoyées par Festy: pour une fois un livre que j'ai écrit me fait plaisir à relire. $\mathrm{Si}$ je ne me trompe, il devrait avoir du succès auprès des jeunes filles, en mal de famille et de religion et qui n'osent pas encore oser. D'autre part, j'ai pris mon élan, je crois, pour mon nouveau livre (FCh 2:189, FCirc 429-30, translation altered).]

35 “À l'Université je parlai-non par goût, mais parce qu'on me l'avait demandé-de la condition de la femme" (FCh 2:349, FCirc 552). In their public appearances, both she and Sartre were mainly concerned to gather support for the Cuban revolution, advancing the ideas he'd just articulated in "Ouragan sur le sucre" (Hurricane Over the Sugar).

36 "De nouveau, je parlai des femmes dans une grande salle fleurie et parfumée, devant des dames harnachées qui pensaient le contraire de ce que je disais; mais une jeune avocate me remercia au nom des femmes qui travaillent" (FCh 353, FCirc 555, translation altered). 
self-aggrandizing speeches of de Gaulle. ${ }^{37}$ Even the success of the first two volumes of her memoirs creates mixed emotions.

People would come up to me with beaming smiles and say, "I don't agree with you politically; but I liked your book so much." "Let's hope you don't like the next one," I said to one of them. It is true that in La force de l'âge I had taken a very objective attitude toward my past beliefs; all the same, I did make it perfectly clear how distasteful I find bourgeois institutions and ideologies; I shouldn't have been receiving the approval of people who were attached to them. ${ }^{38}$

I'm reminded of Richard Wright's determination that his second book, Native Son, would make less room than his earlier writings for what is now called "white tears," and of Beauvoir's later "dialogue of the deaf" with Betty Friedan. At one point she describes her support for a Doctor Weill-Hallés crusade for birth control, noting the shockingly conservative attitude of the French communist party; she is asked to, and does, write prefaces for two short books, $L e$ planning familial and La grande peur d'aimer. But she describes the press conference for the second book as depressing.

There were about a hundred people there: psychoanalysts, doctors, various more or less qualified specialists in the human heart. Mme. Weill-Hallé in a white dress, blonde, virginal-looking, expounded in her musical voice on the advantages of the pessary; some fifty-year-olds asked uneasily if the use of such things was not harmful to the romantic side of love. The vocabulary employed was edifying in the extreme. They talked, not about birth control but about the joys of maternity, not about contraception but about orthogenesis. At the word abortion, faces were turned away; as for sex, that wasn't allowed in the room at all. ${ }^{39}$

37 “Tout en réclamant pour son investiture une procédure exceptionnelle, de Gaulle avait fait savoir qu'il voulait être légalement appelé par le pays. Des dames du monde écoutaient, en extase; Mauriac se pâmait" (FCh 2:151, FCirc 401).

38 "Les gens me disaient avec d'éclatants sourires: 'Je ne suis pas d'accord avec vous, politiquement; mais votre livre m'a tellement plu!- J'espère que le prochain déplaira,' dis-je à l'un d'eux. Il est vrai que dans La force de l'âge je prenais certaines distances par rapport à mes attitudes passées; tout de même j'y disais clairement mon dégoût des institutions et des idéologies bourgeoises; je n'aurais pas dû obtenir les suffrages de ceux qui leur étaient attachés" (FCh 2:404, FCirc 593). See also FCh 2:497, FCirc 665.

39 "Il y avait une centaine de personnes: des psychanalystes, des médecins, des spécialistes plus oumoins autorisés du cœurhumain. Mme. Weill-Halléen robeblanche, blonde, fraîche, virginale, exposa d'une voix musicale les avantages du pessaire; des quinquagénaires 
It would not be until 1970 that she would be contacted by the younger generation of militants from the MLF (Mouvement de libération des femmes), with whom she'd have more in common. For now, she quickly turns back to the urgency of defending Jeanson and Alleg. As she observes (in a different context): "The war in Algeria was mobilizing all my emotions. I had none left over for anything else." 40

I think Golay is also right when she defends that priority, using Beauvoir's own language from Pour une morale de l'ambiguïté:

Because oppression has more than one face, if in the historical context of the late ' 50 s and early'6os Beauvoir's feminist engagement seems to have been subordinated to the struggle for decolonization, it's on the one hand because the urgency of the situation demanded it, and on the other because the liberation of colonized nations would serve the struggle for women's liberation (as Fanon argues in "LAlgérie se dévoile"): "First things first," one might say, taking Kirsten Holst Petersen's formulation. ${ }^{41}$

By 1972, Beauvoir would acknowledge that the second part of that reasoning had been over-optimistic, writing in Tout compte fait: "Fanon was profoundly mistaken when he foretold that the Algerian women would escape from male oppression because of the part they had played in the war." ${ }^{22}$ But as Beauvoir also says in Pour une morale de l'ambiguité, one makes choices about this kind of thing without being able to know in advance whether one will be right: we're

demandèrent avec inquiétude si l'usage n'en était pas nuisible au romantisme amoureux. Le vocabulaire employé était des plus édifiants. On parlait non de 'birth-control' mais de maternité heureuse, non de contraception, mais d'orthogenèse. Au mot avortement, on se voilait la face; quant au sexe, il n'était nulle part" (FCh 2:297-98, FCirc 512-13).

40 She has met an old friend who is devastated by a different injustice, the execution of Caryl Chessman in the US: “La guerre d'Algérie mobilisait mes émotions, je n'en avais plus de reste, mais je la comprenais” (FCh 2:306-7, FCirc 519).

41 "Loppression ayant plus d'un visage, si dans le contexte historique de la fin des années 50 et du début des années 6o, l'engagement féministe de Beauvoir semble subordonné à la lutte pour la décolonisation, c'est d'une part que l'urgence de la situation l'exigeait, et d'autre part, que la libération des nations colonisées servait la lutte de libération des femmes (ce que défend Fanon dans 'L'Algérie se dévoile'): 'First things first,' pourrait-on dire en reprenant la formule-titre de Kirsten Holst Petersen" (Golay, "Féminisme et postcolonialisme," 423). Golay is referencing PMA 14, EA 10; see chapter 3 above. See also Petersen, "First Things First."

42 "Fanon s'est bien trompé quand il prédisait que grâce au rôle qu'elles ont joué pendant la guerre les femmes algériennes échapperaient à l'oppression masculine (Tout compte fait [hereinafter TCF], 562; All Said and Done [hereinafter $A S D$ ], 443). I'll return below to the wider context for this passage. 
not in the world of trolley problems now. And perhaps, looking back later, one would still feel one's choice had been the right one, much as she'd said no one had the right to judge Richard Wright's view that, for American Blacks in the 1940s, the war effort was less urgent than their own liberation.

But where Golay, honoring an important strand of postcolonial critique, says "first things first," Beauvoir's own formulation, both in Pour une morale de l'ambiguité and here, seems a little different: I expressed it (with reference to Anna Julia Cooper) as one thing at a time. If we wait for the perfectly intersectional action, we will wait forever; plus, in the real world, certain desiderata are genuinely incompatible, and nothing is gained by pretending otherwise. (This is also, I think, one important takeaway from Kimberlé Crenshaw's original article.) ${ }^{43}$ Perhaps here is as good a place as any to remind my reader (and myself) that what is an issue is not whether Beauvoir was "a good person." ${ }^{44}$ Of course, after all these pages (and all these decades) I can't help but hope so; but she herself would have regarded that issue as pretty much irrelevant, and as a bit of a trap. ${ }^{45}$ The question I began with was a different one: how can her thinking-in-situation (including the thinking she did in her autobiographical writing), from her situation, be of use to us in ours. ${ }^{46}$

In retrospect, only one of the two justifications Golay saw Beauvoir as offering for prioritizing the anti-colonial struggle (and de-centering more obviously "feminist" concerns) would hold water. But the most we can ask is that people make a good faith judgement based on what was available to them at the time. With respect to Algeria, as always, Beauvoir documents her response, both intimate and collective, ${ }^{47}$ to facts on the ground as they appear to her; and does not hesitate to say, later, when she turns out to have been wrong.

43 See Qrescent Mali Mason, "Intersectional Ambiguity and the Phenomenology of \#BlackGirlJoy."

44 Whatever we mean by that. And what do we mean by that? For women especially, there's a depressing amount of overlap between "a good person" and "a nice person." Perhaps this is another situation where policing a boundary is not an especially good use of one's energy, even (especially?) when one is thinking about oneself.

45 See for example her discussion of "dévouement" and of the "dame de charité" in The Second Sex, but also in Pour une morale de l'ambiguité, where it is formulated in a more genderneutral way.

46 I follow Ursula Tidd (Gender and Testimony) and Karen Vintges (Philosophy as Passion) in taking Beauvoir's autobiographical works as a key aspect of her theory, and of her theory's impact on women and the women's movement internationally.

47 "Writing the self and writing history are woven into one and the same gesture of writing." [L'écriture de soi et l'écriture de l'histoire se tissent ici en un seul et même geste d'écriture (Golay, “Féminisme et postcolonialisme," 415).] 
It may be worth underlining this. Beauvoir is a remarkably consistent thinker and writer, when compared to, say, Gide or Malraux, or even Sartre; it is striking, for instance, that the same views and even the same examples recur in writing of very different periods and genres. But in their search for "Beauvoir," commentators often miss the way she undertakes to document the uncertainties and evolutions in her thinking, ${ }^{48}$ and the way many of her texts, as Golay says of this one, look forward to their own "dépassement." 49 One should not ignore the warning at the beginning of La force des choses:

Like its predecessor, this book asks the reader for his collaboration. I present, in order, each moment of my development, and the reader must have the patience not to close the accounts before the end. He is not entitled, for instance, to conclude, as one critic has done, that Sartre likes Guido Reni because he liked him when he was nineteen. Indeed, only malice dictates such blunders, and against malice I do not intend to be on my guard. On the contrary, this book contains everything likely to provoke it, and I should be disappointed if it failed to displease someone. I should also be disappointed if it pleased no one, and that is why I suggest that its truth is not expressed in any one of its pages but only in their totality. ${ }^{50}$

48 As I discussed above, Mary McCarthy could only see the different views in L'Amérique au jour le jour 1947 as an incoherent mess; others have followed her lead in picking out and attacking isolated points, identifying those as "Beauvoir." What is often missing (whether through bad faith or "déformation professionnelle") is the habit of reading dialectically.

"The text of La force des choses, which looks forward to its own dépassement, this tense and straining text, has an even more forceful effect on the reader because Beauvoir gives us the whole story of the road she took, with a constant concern for the truth, making no attempt to disguise her own contradictions, but rather forcing herself to take hold of them in the very gesture of writing." [Le texte de La force des choses, qui vise son propre dépassement, ce texte tendu, peut être reçu par le lecteur avec d'autant plus de force que Beauvoir y livre son cheminement dans son ensemble avec un souci constant de vérité, ne cherchant en rien à masquer ses propres contradictions, mais s'efforçant au contraire de les saisir dans le geste même de l'écriture (Golay, "Féminisme et postcolonialisme," 419).]

"Comme le précédent, ce livre demande au lecteur sa collaboration: je présente, en ordre, chaque moment de mon évolution et il faut avoir la patience de ne pas arrêter les comptes avant la fin. On n'a pas le droit par exemple, comme l'a fait un critique, de conclure que Sartre aime Guido Reni parce qu'il l'aima à dix-neuf ans. En fait, seule la malveillance dicte ces étourderies et contre elle je n'entends pas me prémunir: au contraire, ce livre a tout ce qu'il faut pour la susciter et je serais déçue s'il ne déplaisait pas. Je serais déçue aussi s'il ne plaisait à personne et c'est pourquoi j'avertis que sa vérité ne s'exprime pas dans aucune de ses pages mais seulement dans leur totalité" (FCh 1:10, FCirc 7). 
La force des choses ends with a kind of balance sheet, where she responds in firm feminist tones to those who have criticized her relationship with Sartre, or insinuated that he writes her books for her, ${ }^{51}$ or painted a wounding picture of her personality, describing her as a madwoman, an eccentric, dissolute, a schoolmistress, a conformist: any number of incompatible slurs. ${ }^{52}$ But she then moves into an assessment of her objective situation:

I know that I am a profiteer, and that I am one primarily because of the education I received and the possibilities it opened up for me .... [T] he people who buy my books are all beneficiaries of an economy founded upon exploitation. I am an accomplice of the privileged classes and compromised by this connection; that is the reason why living through the Algerian war was like experiencing a personal tragedy. ${ }^{53}$

The primary commitment is to decolonization, to anti-racism, to the Third World. "For now I know the truth of the human condition: two-thirds of

$5^{1} \quad$ See FCh 2:49o, FCirc 66o.

$5^{2}$ "In France, if you are a writer, to be a woman is simply to provide a stick to be beaten with ... I am of the Left, I had things I was trying to say; among others, that women are not just a tribe of moral cripples from birth." [En France, si vous écrivez, être femme c'est donner des verges pour vous battre .... Je suis de gauche, j'ai essayé de dire des choses, entre autres, que les femmes ne sont pas des éclopées de naissance [FCh 2:492, FCirc 661).]

53 “Je sais que je suis une profiteuse, et d'abord par la culture que j'ai reçue et les possibilités qu'elle m'a fournies .... [L]es gens qui achètent mes livres sont tous les bénéficiaires d'une économie fondée sur l'exploitation. Je suis complice des privilégiés et compromise par eux: c'est pourquoi j'ai vécu la guerre d'Algérie comme un drame personnel" (FCh 2:501, FCirc 668-69).

She returns also to the contradiction about her readership I mentioned above: "My relationship to the public has become ambiguous because the horror my class inspires in me has been brought to white heat by the Algerian war... I feel ill at ease if the middle class as a whole gives me a good reception. There were too many women who read The Memoirs of a Dutiful Daughter because they enjoyed the accuracy with which I had depicted a milieu they recognized, but without being at all interested in the effort I had made to escape from it. As for The Prime of Life, many's the time I've stood gritting my teeth as people congratulated me: 'It's bracing, it's dynamic, it's optimistic,' when I was so sickened by everything that I would rather have been dead than alive." [Mon rapport au public est devenu très ambigu parce que la guerre d'Algérie a porté au rouge l'horreur que m'inspire ma classe.... [J]'éprouve un malaise si la bourgeoisie dans son ensemble m'accueille bien. Trop de lectrices ont apprécié dans les Mémoires d'une jeune fille rangée la peinture d'un milieu qu'elles reconnaissaient, sans s'intéresser à l'effort que j'avais fait pour m'en évader. Quant à La force de l'âge, j'ai souvent grincé des dents quand on me félicitait: "C'est tonique, c'est dynamique, c'est optimiste," à un moment où tel était mon dégoût que j'aurais mieux aimé être morte que vive (FCh 2:497, FCirc 665).] 
mankind are hungry." ${ }^{4}$ France is where she is, she is in it and of it, and she does not pretend or fantasize otherwise: like Pierre in L'invitée, she cannot imagine writing from a position of exile. But France is not the world, or the center of the world.

A Response to "Occidental Dreams"

But wait a minute, you say. Didn't I read somewhere that Beauvoir was a terrible orientalist?

Sigh. Yes, you did.

As I mentioned above, Sally Markowitz's article, "Occidental Dreams: Orientalism and History in The Second Sex," takes Beauvoir to task for being embedded in some problematic discourses about "the oriental," and scolds Beauvoir scholars for having ignored this. In Markowitz's view, The Second Sex is rendered less than useful for present-day feminists by traces of an outdated rhetoric of ethnic difference in Beauvoir's account of the "progress" East and West have made toward gender equality. Markowitz sees Beauvoir as closer to Havelock Ellis "whom Beauvoir cites respectfully in The Second Sex," and to the integral racism of Hegel's theory of historical progress, than to "us today"; it would be a caricature to say that Beauvoir gets raked over the coals for not having read Edward Said, but that is the general drift. Markowitz assimilates Beauvoir to a whole history of white women's imposition of exclusionary theory on peoples of color, and on that basis claims that her work is outdated and irrelevant. ${ }^{55}$

Markowitz's article is a polemic, rather than a work of textual scholarship: her claim that The Second Sex associates gender and oriental "race" in an embarrassingly retrograde way rests on two short quotations-four sentences in all - from that eight-hundred-page book. One occurs in a footnote, at the end of part 2 of the five-part "Histoire" section. Beauvoir has been pointing forward to a discussion of the ambiguity of modern man's "Othering" of women: no longer satisfied with nakedly dominating her as a pure object, his "problem"

54 “Car je connais à présent la vérité de la condition humaine: les deux tiers de l'humanité ont faim" (FCh 2:503, FCirc 670).

55 "The Second Sex, for all its brilliance, reflects a time increasingly remote from our own and thus inevitably marked by ways of thinking we would rather forget. Indeed, there is reason to regard Beauvoir as a figure in some respects as close in spirit to, say, the early twentieth-century sexologist Havelock Ellis (whom Beauvoir cites respectfully in The Second $S e x)$ as to the feminists she would provoke and inspire in the 1970 s and beyond" (Markowitz, "Occidental Dreams," 271). 
will become how to make her his "companion" while still maintaining her subservient status. ${ }^{56}$ Then the footnote explains that she'll be describing this modern development in the West, since that is where it has occurred: "the history of women in the East, in India, in China, has been in effect the history of a long and unchanging slavery."57 The second passage Markowitz cites, which occurs in Beauvoir's chapter on "myths," is indeed a stereotyped generalization, something that (to borrow Nancy Bauer's phrase) "hurts my ears,"58 as I'll discuss fully below: Beauvoir contrasts an "Oriental" man who views women as objects of pleasure to a modern Western man who dreams of embracing "another free being."59 But Markowitz pulls these two passages out of context, and she doesn't engage with any of the other, more substantive things Beauvoir says in The Second Sex about China, India, and the Arab world. The "oriental other," Markowitz says, "haunts the margins" of The Second Sex; ${ }^{60}$ but she seems unable or unwilling to cite further examples of his actual presence in Beauvoir's actual text. Nonetheless, her description of Beauvoir as an "orientalist" has become a routine, dismissive gesture in the general feminist literature, taking its place alongside older accusations that Beauvoir is a "liberal feminist" in the model of Betty Friedan, and that she writes only from the viewpoint of her own race and class and has "nothing to say" about, or to, anyone else.

Why do I find it so hard to be charitable to this article? It does not add anything to our understanding of Simone de Beauvoir — but then, that was not the writer's intention. We are expected to simply accept on faith Markowitz's claim that her two brief quotations "cast a long shadow" over Beauvoir's work and her career, without supporting argumentation. ${ }^{61}$ Markowitz barely talks about any more of The Second Sex than Lucy did. ${ }^{62}$ Instead, most of her article

$5^{6} \quad D S_{1: 135}-36$.

57 "Nous examinerons cette évolution en Occident. L'histoire de la femme en Orient, aux Indes, en Chine a été en effet celle d'un long et immuable esclavage. Du Moyen Âge à nos jours nous centrerons cette étude sur la France dont le cas est typique" (DS 1:136).

$5^{8}$ Nancy Bauer, "On the Limits of Philosophizing," 2.

$59 D S$ 1:237.

6o Sally Markowitz, "Occidental Dreams: Orientalism and History in The Second Sex," 286.

61 Why did a major, well-respected academic feminist journal fail to pick up on this elementary methodological point? Perhaps the view is taken that racism in feminism is such an emergency that other matters must take a back seat. Or perhaps it is Spelman who casts a long shadow here, even though, as Markowitz rightly says, her own arguments are different ones.

62 She's also not quite right when she announces herself triumphantly as the first to have taken notice of the passages she discusses: Margaret Simons noted that Beauvoir "consigns the majority of the world's women to a footnote" in an article, "Sexism and the Philosophical Canon: On Reading Beauvoir's The Second Sex," first published in 1990 and 
expands on what is wrong with the "discourse" in which Beauvoir allegedly participates: Markowitz rehearses a grand narrative about the racialization of the sex/gender difference in the grand narrative of the West, using as her examples other writers, including some who may have been unknown to Beauvoir. (For example, she adduces the shortcomings of Charlotte Perkins Gilman, without showing any relationship between Gilman and Beauvoir-and I don't believe there was one: Gilman's work was pretty well forgotten in the United States by the time Beauvoir traveled there, and remained little-known until feminists rediscovered her work in the 1970s.) Markowitz explains what she is criticizing as follows:

By the racialization of sex/gender difference, I mean that constellation of views, prevalent in the nineteenth and early twentieth centuries, that correlated greater "racial advancement" with greater sex/gender difference between the men and women of a particular race: the more "advanced" the race-so the story went- the greater the differences between men and women of that race. ${ }^{63}$

But in fact, even the most painful passages Markowitz pulls out from The Second Sex do not talk about differences between men and women, or between masculinity and femininity: they are talking about how different groups of men relate sexually to women, which is not the same thing at all. ${ }^{64}$ Tina Chanter says something in another connection that I find apposite here:

Of course, anything anyone says about anyone anywhere is fair game, once it is out there in the world.... But I do have a question about the ethics and politics of readings which focus on strategic alignments and produce a homogenizing string of feminist authors, all of whom are represented as

reprinted in her 1999 collection, which Markowitz lists in her references. But she may well be the first to have made such a meal of it.

63 Markowitz, "Occidental Dreams," 274.

64 In what follows below, I will analyze all the other passages that relate to Arabs, Islam, harems, the "Orient" and or the "East." While there are indeed strange things to see, I cannot find a discussion of progress toward greater gender differentiation anywhere. By extrapolating, in fact, one might deduce the opposite: it is the average modern Occidental man who sees his wife (at least some of the time) as his "semblable." Beauvoir does find this preferable-Markowitz is right that, pace Bergoffen, Beauvoir favors what Thomas Laqueur named the "one-sex model"—or, as she might have called it, humanism. I myself know some women who would agree with her. (This is not the place to explore how fully Laqueur's own historical scheme has been cast into doubt by other scholars.) 
saying more or less the same thing, despite the fact that their political and ethical sensibilities might be entirely divergent. ${ }^{65}$

However, in another way, Markowitz's two passages are very well chosen, in that they are guaranteed to make "the woman of today" - that is to say, the academic feminist of today-wince, blush, and desperately wish herself elsewhere.

One may interpret this passage [the footnote] generously, overlooking Beauvoir's easy generalizations about non-Western cultures, but later in the book one encounters this troubling explanation of what makes gender relations in the modern West so special: "The more the male becomes individualized and lays claim to his individuality, the more certainly he will recognize also in his companion an individual and a free being. The Oriental, careless of his own fate, is content with a female [femelle] who is for him [an object of pleasure]; but the dream of the Occidental, once he rises to consciousness of his own uniqueness, is to be taken cognizance of by another free being, at once strange and docile."66

This seems quite obtuse, by the standards of any age. So what is it doing here? What might Beauvoir have intended?

One thing to notice is that the passage occurs in the section on "Mythes." This section follows the "Histoire" section; Beauvoir explains that she intends to supplement her earlier discussion of women's concrete economic and judicial subjugation to men with a discussion of the latter's "ontological and moral pretentions." ${ }^{67}$ Here Beauvoir reports on quite a few crazy ideas, the overwhelming majority of which are Western and Christian. In a sense, the entire chapter needs to be put within scare quotes: it is a compilation of things that

65 Tina Chanter, "The Trouble We (Feminists) Have Reasoning With Our Mothers," 492. Chanter was responding to Penelope Deutscher's use of Chanter's own work in Yielding Gender.

Having argued that Beauvoir received Hegel, not directly, but via Marx, Markowitz also spends several pages exploring whether or not Marx was an "orientalist," in a way which is significantly more respectful of the nuances of that question: but if Marx is an important enough thinker that one or two quotations from his work should not condemn him out of hand, why not extend that same contextualizing courtesy to Beauvoir?

66 The French, which Markowitz does not give, reads as follows: "L'Oriental insouciant de son propre destin se contente d'une femelle qui est pour lui un objet de jouissance; mais le rêve de l'Occidental, quand il s'est élevé à la conscience de la singularité de son être, c'est d'être reconnu par une liberté étrangère et docile" (DS 1:281).

67 “[P]rétentions ontologiques et morales" (DS 1:237). 
are not true, but that have nonetheless been powerful. Remember that the overall title of volume 1 is "Les mythes et les faits," myths and facts, and that it is shaped by a dialectic relationship between what women "are seen as," and what they are, or could be. "If woman did not exist, men would have invented her. They did invent her. But she also exists." ${ }^{68}$ So to take any isolated sentence from the myth section as "Beauvoir" would be, at best, naïve: Beauvoir investigates myth in order to demystify. As Fanon said, "Nous faisons ici le procès des mystifiés et des mystificateurs." ${ }^{69}$ Both those who make myths, and those who fall for them, are on trial.

Like the rest of The Second Sex, the myth chapters are a patchwork quilt of strange and contradictory things which nonetheless add up to an argument, if one has the patience to wait for it. Markowitz sees her chosen passage as "a troubling explanation of what makes gender relations in the modern West so special"; to my mind, it forms part of a lengthy indictment of how modern Western men behave, even as they pat themselves on the back for their greater enlightenment. We might remember what short work Beauvoir made, in Pour une morale de l'ambiguité, of le colon's supposed arguments for his own superiority.

Beauvoir has a fair amount to say, in The Second Sex, about India, China, the Arab world, and various ethnographically-documented "peoples"; her study of the "non-Western" was far from a cursory afterthought. For instance, quite early in the Introduction, and central to her development of the primordial category of Otherness (prior to its sexual differentiation), we find a reference to Granet's works on "Chinese Thought" and Dumézil's scholarship on India and Rome. ${ }^{70}$ What led Markowitz to single out the particular tidbit she cites? Even if she'd wanted to stick to the realm of desire, she could have chosen the following one, from the chapter on "Initiation sexuelle":

$68 D S_{1: 303}$. I discuss this passage above in connection with Richard Wright.

$69 \quad$ Peau noire masques blancs [hereinafter $P N M B$ ], 25; Black Skin White Masks [hereinafter $B S W M] 17$, translation altered.

70 "The category of the Other is as primeval as consciousness itself. In the most primitive societies, the most ancient mythologies, there is always a duality of Same and Other; this division at first was not placed under the sign of the division of the sexes, it was not based on any empirical given: this emerges from the research of Granet on Chinese thought, from Dumézil's work on Rome and India, among others." [La catégorie de l'Autre est aussi originelle que la conscience elle-même. Dans les sociétés les plus primitives, dans les mythologies les plus antiques on trouve toujours une dualité qui est celle du Même et de l'Autre; cette division n'a pas d'abord été placée sous le signe de la division des sexes, elle ne dépend d'aucune donnée empirique: c'est ce qui ressort entre autres des travaux de Granet sur la pensée chinoise, de ceux de Dumézil sur les Indes et Rome ( $D S$ 1:16).] 
It appears that in India the husband, while fulfilling his conjugal duty, happily smokes a pipe to distract himself from his own pleasure, so that his wife's pleasure can last longer; in the West, in contrast, a Casanova will brag about the number of his "coups," and his greatest pride is to make his partner beg for mercy; according to the tradition of erotica, that is a rare exploit... ${ }^{71}$

"Gender relations in the West" are hardly being shown here as "special": surely one would rather be in bed with this considerate Indian fellow than with any of the sadistic Parisian and Viennese husbands, casual rapists, and self-centered premature ejaculators catalogued in that chapter?72 Except that "the Indian husband" is undoubtedly imaginary, a hasty over-generalization from (maybe) the Kama Sutra, just as Markowitz's insouciant oriental was a hasty over-generalization from the Thousand and One Nights, or some such. Really both are deployed as illustrations, or foils, rather than argument or evidence. The tactic is similar to Foucault's contrast, in the first volume of his History of Sexuality, between an Eastern "ars amatoria" and a Western "scientia sexualis," and it is deployed for a quite similar purpose: to problematize (and, subliminally, to criticize) the habitual practices and discourses of sexuality in the West, by showing that another approach is possible. And yes, the use of non-Western examples purely for contrast is a familiar orientalist habit; and the failure to locate non-Westerners as distinct agents in real historical time is another. But I see no argumentation that would lead me to believe that the careless oriental of Markowitz's passage "casts a long[er] shadow" than the thoughtful Indian husband, or indeed that either has any importance beyond the page on which he appears.

In some ways this is the same question of method I discussed above: when a reader balks at something in a text, how is she to decide whether that "something" is, to put it crudely, a dealbreaker, or merely a regrettable lapse in an

$71 \quad$ "Il parait qu'aux Indes l'époux, tout en remplissant ses devoirs conjugaux, fume volontiers la pipe afin de se distraire de son propre plaisir et de faire durer celui de son épouse; en Occident, c'est plutôt du nombre de ses 'coups' que se vante un Casanova; et sa suprême fierté, c'est d'obtenir que sa partenaire crie merci" ( $D S$ 2:180). This illustration follows up on statistical information, drawn from Kinsey, about the difference in time men and women require to reach orgasm.

72 Perhaps my reader will remember (from chapter 1) Dr. Grémillon, the war hero Beauvoir quoted ( $D S$ 2:237) in her discussion of orgasm: "The modern woman wants to be made to vibrate. We reply: Madam, we haven't got the time, and hygiene forbids it!" Actually, in this context, Markowitz's own quotation might look somewhat less critical of the "Oriental" than she thinks - the "insouciant Oriental" seems more interested in sexual pleasure, $p e$ riod, than in the use of sexual pleasure as a tool of domination. 
otherwise valuable work? ${ }^{73}$ Are Markowitz's two passages about "the Orient" on the level of Beauvoir's usage of "he," where we might wish she'd said "he or she"-a surface irritant, which one can describe as "of its time" - or do they betray a deeper obtuseness against which readers must be warned? Perhaps the latter case can be made, but no one has taken the trouble to actually make it. What's frustrating to me is that, while Markowitz does a fine job of explaining the ideology she is taking issue with (the subject of her own earlier book), she does not do the textual work of connecting what she is against to Beauvoir's work, and she fails to see The Second Sex as a whole.

Instead, she makes Beauvoir responsible for all the faults of everyone she cites. But "cites respectfully" is not the right way to understand how Beauvoir uses Havelock Ellis, or sources generally, as I hope I've explained fully in chapter 1. For instance, one place Beauvoir cites Ellis is a long footnote in the "Initiation sexuelle" chapter listing a variety of objects that doctors have removed from women's vaginas. Beauvoir's point here is that, despite what Kinsey says about the lack of nerve endings in the vagina, women do, apparently, find enough sensation present there that some among them find it worthwhile to masturbate, using, um, a range of items. ${ }^{74}$ Maybe you didn't want to know this; but I can't find anything wrong with Beauvoir's logic, her conclusion appears reasonable, and her "methodology" appears to value plain old empirical evidence. If that is "outdated," I don't know what to say.

Actually, since the Kindle makes this so easy now, why not finish the job? The list of dildoids is one of nine references to Havelock Ellis in The Second Sex. All are very brief. In four, all she is interested in is the first person narrative he has collected; ${ }^{75}$ in three others, she uses his statistics; ${ }^{76}$ the last one refers very

73 This question cuts both ways: as I discussed above regarding Debra Bergoffen's work, is it fair to pull out a few passages one likes and agrees with, and develop them into an interpretation one then labels as "Beauvoir"?

74 DS 2:149.

75 She quotes a patient he calls Zenia to the effect that the noise of a jet of water was sexually exciting ( $D S$ 2:22); one of the cases Stekel analyses (Florrie) was originally Ellis's case (2:23); at 2:198, there is a reference to "the homosexuals' confessions collected by Ellis and Stekel" [les confessions d'inverties ... qu'ont recueillies Havelock Ellis et Stekel]—from both, she uses only the first-person quotation; at 2:206, one of the stories Havelock Ellis recounts concerns "a subject ... who detested her mother throughout her childhood" [Un des sujets dont Havelock Ellis raconte l'histoire et qui avait détesté sa mère pendant toute son enfance] and how this influenced the girl's first lesbian experience.

76 At $D S$ 2:50, his results show that more girls want to be boys than boys want to be girls, and this is followed up with a corroborating result from a more qualitative study done by someone else. At 2:68 she discusses a survey he cites that "out of 125 American high school students thirty-six at the time of their first period knew absolutely nothing of the question, and thirty-nine had vague ideas.... Ellis cites the case of a young girl who threw 
briefly to a concept he called "undinism," a term that, indeed, one rarely hears nowadays (it never caught on), but all it means is "urinary eroticism," which still exists, from what I read on the internet. ${ }^{77}$ Furthermore, Ellis's legacy to sexology and gay liberation is a mixed one, as Markowitz herself notes: he had some dumb ideas, and also some better ones (and his ideas about "inversion" look different, and better, in the age of "trans" than they did twenty years ago). But it hardly seems worth dwelling on that here, since Beauvoir's "use" of Ellis is actually quite cursory. As with Stekel, she seems to have mined him for information rather than taken him as a mentor or guide. The only thing she quotes from him that might rise to the status of an actual idea is the statement that there is more rape inside marriage than outside of it: ${ }^{78}$ this has nothing to do with an evolutionary view of race, or with race at all.

And what does "cites respectfully" mean, exactly? If all of us were to blame for all the faults of everyone whose work we cited, who among us would 'scape whipping? Following out Penelope Deutscher's nice metaphor of Beauvoir's eclectic assemblage of theorists as a dinner party where the guests don't get along: ${ }^{79}$ suppose I invite Heidegger to my party (or, suppose my boyfriend asks if he can bring him along and I say, oh well, ok). Am I then personally responsible

herself into the Seine in Saint-Ouen because she thought she had an "unknown disease" [D'après une enquête rapportée en 1896 par Havelock Ellis, sur 125 élèves d'une "highschool" américaine, 36 au moment de leurs premières règles ne savent absolument rien sur la question, 39 avaient de vagues connaissances.... H. Ellis cite le cas d'une jeune fille qui s'est jetée dans la Seine à Saint-Ouen parce qu'elle se croyait atteinte d'une "maladie inconnue."] (Others cited on this point include Helene Deutsch, Melanie Klein, and a memoir by Beauvoir's friend Colette Audry). At 2:248, he is quoted as saying that there are more rapes inside than outside of marriage ["Il y a certainement plus de viols commis dans le mariage que hors du mariage," dit Havelock Ellis], and lower down the page he is cited as objective support for the misery of women's sexual initiation: "In England, Ellis reports, a woman asked six intelligent, married, middle-class women about their reactions on their wedding night: for all of them, intercourse was a shock." [En Angleterre, rapporte Havelock Ellis, une dame demanda à six femmes mariées de la classe moyenne, intelligentes, leur réaction pendant la nuit de noces: pour toutes le coït était survenu comme un choc; deux d'entre elles ignoraient tout; les autres croyaient savoir mais n'en furent pas moins psychiquement blessées.]

77 This occurs in the chapter on narcissism: another footnote says a case of Dalbiez "confirms Havelock Ellis's ideas of the relation between narcissism and what he calls 'undinism,' that is, a certain urinary eroticism" [ce qui confirme les idées d'Havelock Ellis sur le rapport entre le narcissisme et ce qu'il nomme "ondinisme," c'est-à-dire un certain érotisme urinaire (DS 2:526)]. "As we now know," Ellis was drawing on the authority of personal experience here. See Phyllis Grosskurth, Havelock Ellis: A Biography, 365-66.

$78 \quad D S 2: 248$.

79 Deutscher, The Philosophy of Simone de Beauvoir: Ambiguity, Conversion, Resistance, $11-13$. 
for everything he says at the table? Everything he says at my table, maybe that's fair, unless I say something back to him about it at the time. ${ }^{80}$ But everything else he ever said ever? ${ }^{81}$ And $h$ is friends? And with respect to her use of Hegel: is there any twentieth-century critical theorist who wasn't, on some level, friends with Hegel ${ }^{82}$ Do we have to throw out all of standpoint theory, too? ${ }^{83}$

So Beauvoir should not have used Ellis and Hegel; Second Wave feminists should not have used Beauvoir; I should not use those Second Wave feminists; students now, presumably, should not use me. What a relief: the reading list is now much, much shorter! No, this can't be right. This can't be what Markowitz means.

But what is to be feared if these things are not pointed out? That the younger generation will be corrupted by tainted discourses? It still does not seem possible to treat Simone de Beauvoir as a thinker, rather than as a mother who

8o Beauvoir is very clear that many of Hegel's ideas were repugnant to her, in The Second Sex, in Pour une morale de l'ambiguïté, in her memoirs.... Markowitz does not engage with this, or with the considerable secondary scholarship on the question.

81 I'm channeling the flap occasioned in continental philosophy circles by the publication of Heidegger's Black Notebooks. A prominent Heideggerian resigns, and people go, why resign only now? We knew that. The issue is how thoroughgoing was Heidegger's antiSemitism. Some people privilege the private texts in deciding that; others feel just the opposite; some even feel that what Heidegger did personally during the war actually matters, too. See Sarah Bakewell, At The Existentialist Café: Freedom, Being, and Apricot Cocktails with Jean-Paul Sartre, Simone de Beauvoir, Albert Camus, Martin Heidegger, Karl Jaspers, Edmund Husserl, Maurice Merleau-Ponty, and Others.

82 See for instance Susan Buck-Morss, Hegel, Haiti, and Universal History, 15: "[W]e need to consider not only Hegel's Haiti, but Haiti's Hegel, that is, the Afro-Caribbean reception of Hegel that claims him as their own. [Nick] Nesbitt has traced this legacy through the work of Aimé Césaire, whose influential conception of négritude, referring to the African diaspora's self-understanding based on 'a common experience of subjugation and enslavement,' considers the slave's self-liberation in the Haitian revolution as 'emblematic.' Césaire recalled to Nesbitt personally his youthful excitement in discovering Hippolyte's new translation of Hegel's Phenomenology (1941). 'When the French translation of the Phenomenology came out, I showed it to Senghor, and said to him "Listen to what Hegel says, Léopold: to arrive at the Universal, one must immerse oneself in the particular!" Césaire understood that the truly productive, 'universal' experience of reading Hegel is not through a summary of the total and totalizing system, but through the liberation that one's own imagination can achieve by encountering dialectical thinking in its most concrete exemplification." Buck-Morss's citation is to Nesbitt, Voicing Memory: History and Subjectivity in French Caribbean Literature, 120.

83 Actually, much as I like it, the dinner party analogy is a bit misleading: it wasn't people Beauvoir invited to dinner, it was ideas. And most powerful ideas (good and bad) have more than one parent: Markowitz and many others derive the racism in philosophy from Hegel, a recent Aeon article derives it just as convincingly from Kant (Bryan Van Norden, "Why the Western Philosophical Canon is Xenophobic and Racist"). 
is required to be either perfect or terrible. What accounts for this lack of generosity, I think, is the belief that policing the purity of others will guarantee our own. But that is magical thinking. Markowitz announces rather smugly that Beauvoir seems "all but unaware of her own orientalism." ${ }^{\text {4 }}$ Like Freud or Stekel: "I brought her to admit..." Aha! A racist moment! Is the project simply to catch people out? Wasn't there a different project? Is it comprehensible to speak of collaborating with writers of the past? Of working in coalition with them?

But there I go again using the dated language of the shared "project." Markowitz seems really to be against the whole idea of "progress," the underlying optimism of The Second Sex that things for women are getting better, that we're almost there. She's quite snide about this, as though we all agree it was a stupid idea. I really don't know what to say about this. Would a feminism that didn't think things for women were once worse, had gotten better, were getting better, would get better, could get better, really be feminism? I must be missing something.

Anyhow, I almost want to ask Markowitz the question I asked Spelman: who do you think "we" are? The fact is, there is no reason to regard a view of "the East" or "the Orient" as somehow behind or belated or defective or lesser as "dated." There are plenty of people who believe it now. (Many of them have guns.) So what is actually happening is that Markowitz is asserting the existence of a feminist vanguard, or rather, asserting that she is a member of it, that Beauvoir is not, and that $I$ am not. Presumably that's what's bugging me, sorry, that's really dopey. Isn't there also something kind of silly, though, about criticizing Beauvoir for being embedded in a Hegelian teleology of human progress which we have "gotten beyond," since that statement is itself couched in a rather Hegelian and teleological way.... ${ }^{85}$ And now I'm being meta-silly, since that kind of "you're doing what you accuse X of" is easy and boring. Of course what Markowitz means to do is to condemn the specifics of that part of Hegel's account which are racist, and the triumphalist progress narrative which those specifics are mobilized to justify. I condemn those too. But so did Beauvoir.

Now, I am very far from the first to notice about the term "orientalism" that the more different kinds of work it is mobilized to do, the less it can actually accomplish. As Said himself pointed out in an earlier essay, "Traveling Theory,"

84 Markowitz, "Occidental Dreams," 278.

85 The locus classicus for this kind of thing is Julia Kristeva's "Women's Time," which ... now looks terribly ... dated ... OK, I can't help it, either. 
"a breakthrough can become a trap."86 When Markowitz says that a "postcolonial" reading of Beauvoir is in tension with a more "philosophical" reading, I think she means (and this is a fair criticism) that philosophical readings have attended insufficiently to the political history of concepts. But her own reading also fails to do so. The power of Edward Said's analysis was that he linked a system of ideas, beliefs, ways of seeing and thinking — "orientalism" - to an economic and political system, colonialism/imperialism, which involved the violent extraction of resources from whole sets of people, the institution of regimes of terror, etc., for which a set of ideas about "civilization," "barbarism," "progress," and so on served as an excuse. (This is Fanon's point, too: colonialism is not a thinking-machine. $)^{87}$ Of course the two are connected: otherwise there would be no point in intervening on the level of ideas at all. But an approach like Markowitz's here abandons the material for the discursive, and then polices the discursive at the level of language. Beauvoir's explicit and principled analysis of and opposition to the practices of colonialism become irrelevant, compared to her failure to cleanse herself from certain unpleasant Hegelian turns of phrase, employed in the course of speaking about something else. This is not, I don't think, what Said had in mind. ${ }^{88}$

86 Said, "Traveling Theory," 56 . It was something of a surprise to me to realize that this essay, whose title phrase has had such resonance in post-colonial studies, actually (if you look) deals with French and British responses to the work of Georg Lukács ... and the follow-up piece, "Traveling Theory Reconsidered," explores Lukács's possible and salutary impact on the thinking of Frantz Fanon. A similarly nuanced uptake of Foucault's underlying point is visible in Said's work on Conrad.

87 Fanon, Les damnés de la terre, 66. One might say that the distinction I'm making between orientalism as a set of enabling tropes and colonialism as an economic and political system is parallel to the distinction between individual racism and institutional racism, which according to Alison Jaggar was first made by Stokely Carmichael and Michael Hamilton in Black Power in 1967. (Jaggar, "Philosophical Challenges of Gender Justice," 5.)

88 To criticize a writer for "participating in a discourse" that one finds problematic is also a fundamental misapplication of what Foucault meant by "discourse." Ursula Tidd (Gender and Testimony, 154) gives, at greater length, the quotation from the first volume of The History of Sexuality I've referenced several times already: "[W]e must not imagine a world of discourse divided between accepted discourse and excluded discourse, or between the dominant discourse and the dominated one; but as a multiplicity of discursive elements that can come into play in various strategies.... Discourses are not once and for all subservient to power or raised up against it, any more than silences are. We must make allowance for the complex and unstable process whereby discourse can be both an instrument and an effect of power, but also a hindrance, a stumbling-block, a point of resistance and a starting point for an opposing strategy. Discourse transmits and produces power; it reinforces it, but also undermines and exposes it, renders it fragile and makes it possible to thwart it" (Foucault, History of Sexuality: Volume One, an Introduction, 100101). [Il ne faut pas imaginer un monde de discours partagé entre le discours reçu et le 
In my discussion of "the Spelman moment," above, I argued that it was unfair then to set Simone de Beauvoir up as a scapegoat for second wave occlusions of race. I think it's just as unfair now to set her up as a scapegoat for occlusions of colonialism.

$\mathrm{OK}$, but what about the harem? What about the harem? What about the harem?

While Markowitz's two isolated quotations were clearly chosen for their shock value, a better starting point for this discussion is probably Beauvoir's use of the figure of the "harem woman" as a counterpoint to "the Western woman of today." I've already said, in my discussion of Pour une morale de l'ambiguité, that Beauvoir's emphasis there was more on "enfermée" (locked up) than on "harem." But as I promised, I want to return and trace the development of this figure through Beauvoir's work. ${ }^{89}$ Markowitz's article takes us back to a familiar story from La force de l'âge, which happened during the Second World War, while Sartre was on leave from the army:

Gallimard had just brought out [Sartre's] The Imaginary. There Sartre indicated the theory of néantisation which he was working to deepen. In the moleskin notebooks where he took notes on his day to day life along with a heap of reflections upon himself and his past, he was sketching a philosophy; he expounded the main points to me one evening as we were walking around near the Gare du Nord; the streets were bare and humid and I had a sense of irremediable desolation; I had too greatly desired the

discours exclu ou entre le discours dominant et celui qui est dominé; mais comme une multiplicité d'éléments discursifs qui peuvent jouer dans des stratégies diverses .... Les discours, pas plus que les silences, ne sont une fois pour toutes soumis au pouvoir ou dressés contre lui. Il faut admettre un jeu complexe et instable où le discours peut être à la fois instrument et effet de pouvoir, mais aussi obstacle, butée, point de résistance et départ pour une stratégie opposée. Le discours véhicule et produit du pouvoir; il le renforce mais aussi le mine, l'expose, le rend fragile et permet de le barrer (La volonté de savoir: histoire de la sexualité volume 1, 133).]

89 Again, I must apologize for long quotations, which are necessary since I'm arguing that points were taken out of context; and I also apologize for going over ground that has been very well addressed by Patricia Moynagh ("Beauvoir on Lived Reality, Exemplary Validity, and a Method for Political Thought," 16-17), by Sonia Kruks (Retrieving Experience: Subjectivity and Recogition in Feminist Politics, 35), and by others. Markowitz quotes only the last five sentences of this passage, in Kruks' translation, which differs slightly from mine. 
absolute and suffered from its absence not to recognize in myself that useless project toward Being which Being and Nothingness describes. But what a sad deception, this endlessly vain seeking, begun over and over without end, where existence consumes itself! In the days that followed we discussed some particular problems, especially the relation between situation and freedom. I maintained that, from the point of view of freedom as Sartre defined it - not a stoical resignation but an active dépassement of the given-situations are not equivalent. What dépassement is possible for the woman shut up in a harem? Even this imprisonment, there are different ways of living it, Sartre said to me. I dug in my heels for quite a while and only gave in half-heartedly. At bottom, I was right; but to defend my position, I would have needed to abandon the terrain of individualist, idealist morality. ${ }^{90}$

This paragraph is justly famous among Beauvoir scholars, partly because it seems to be one of the earliest sketches of feminist argument Beauvoir attributes to her younger self, partly because many commentators have seen it as a sign of how much better of a social and political thinker she was than Sartre, and how her idea of situation, which would be central to The Second Sex, in some ways preceded his interest in political engagement after the war. Beauvoir's use of "the woman in a harem" is a way of arguing that all situations are not alike and that not all subjects are practically free, even though theoretical freedom may be the heart of what it means to be human. Without the understanding that situations are different, and that situations matter, no understanding of oppression, indeed no politics at all, is possible; without this shift,

9o "L'imaginaire venait enfin de paraître chez Gallimard. Sartre y indiquait la théorie de la 'néantisation' qu'il était en train d'approfondir. Sur les carnets de moleskine où il notait sa vie au jour le jour, ainsi qu'un tas de réflexions sur lui-même et sur son passé, il ébauchait une philosophie; il m'en exposa les grandes lignes, un soir où nous rodions du côté de la Gare du Nord; les rues étaient noires et humides et j'eus une impression d'irrémédiable désolation; j'avais trop souhaité l'absolu et souffert de son absence pour ne pas reconnâ̂tre en moi cet inutile projet vers l'être que décrit Lêtre et le néant; mais quelle triste duperie, cette recherche indéfiniment vaine, indéfiniment recommencée où se consume l'existence! Les jours suivants, nous discutâmes certains problèmes particuliers et surtout le rapport de la situation et de la liberté. Je soutenais que, du point de vue de la liberté, telle que Sartre la définissait—non pas résignation stoïcienne mais dépassement actif du donné-les situations ne sont pas équivalentes: quel dépassement est possible à la femme enfermée dans un harem? Même cette claustration, il y a différentes manières de la vivre, me disait Sartre. Je m’obstinai longtemps et je ne cédai que du bout des lèvres. Au fond, j'avais raison. Mais pour défendre ma position, il m'aurait fallu abandonner le terrain de la morale individualiste, donc idéaliste, sur lequel nous nous placions" (La force de l'âge, hereinafter $F A, 498-99$ ). 
none of Beauvoir's social and political analysis (or Sartre's) could have happened.

But why did she need to situate the oppression of women elsewhere, bringing up the figure of the Other woman, in order for it to become visible? Here's what Markowitz says about the appearance of this figure in Pour une morale de l'ambiguïté:

So the child, the slave, the "Mohammedan woman enclosed in a harem" can be said to be free in only the most attenuated of senses, while the Western woman of today, whose changed situation is accompanied by a new awareness and new possibilities, consents to her unfreedom in a way the others do not. Although The Second Sex, written soon after, may equivocate somewhat on the matter, it suggests that the "Western women of today" and "the Mohammedan woman enclosed in a harem" have something important in common after all: both have female bodies, and so both are viewed as the other by the men of their group. But Beauvoir also insists on a crucial difference between them. Even as she comes to embody the ideal of feminine difference, the bourgeois Western woman has a correspondingly more developed idea of what it means to be a free, autonomous subject. ${ }^{91}$

Now, I may be being obtuse here, but it is very hard for me to see what Markowitz wishes Beauvoir had done. To Spelman's complaint that Beauvoir only discusses women of her own race, nationality and class and generalizes from that about "Woman," Markowitz adds the complaint that when she does discuss women of color, she describes their situation as different from her own. But it was.

She could hardly have turned to Sartre and said, "you're wrong because you are more free than I am." It would not have been true, and she knew it. She was, at that young point in their individual histories, at least as free, and probably more so- as she later explains, he was more tied than she to expectations of

91 There's a slippage in Markowitz's paraphrase from what Beauvoir actually said - "what freedom is possible" - a difference in the actual, material situation - to how the two women thought about their different situations. Markowitz continues: "The Second Sex, moreover, suggests that this idea and the material conditions that make it possible have developed through the evolution of man - that is, of Western man, who increasingly requires his companion to be not merely an object of pleasure, but another free being, a version of himself if not quite his equal." She references the same passage she quoted above, without further support or analysis. 
bourgeois masculine adulthood that he experienced as constraining. ${ }^{92}$ Plus, he was actually in the army, in time of war. ${ }^{93}$ What freedom was available to a Catholic girl from an haut-bourgeois family, who had fought her way out, and was earning her own living and enjoying her sexuality just as she liked? Actually, quite a bit. When Beauvoir implied that women in other parts of the world were less free than she was, that was an accurate statement, and also, in so far as it showed awareness of her own privilege, it was a politically progressive thing to say. The issue is not race or nationality, but the fact that some people (including some people who happen to be women) have more agency than others, and thus (since ought implies can) more ethical responsibility. ${ }^{94}$ The passage from Pour une morale de l'ambiguité draws attention to differences among women, rather than papering them over. ${ }^{95}$ (As I discussed when I analysed this passage at the end of chapter 3 , those differences are not reducible to simple identity categories: some modern European women are not free, some Muslim women may be free, although which Muslim women these are, and how we can tell, remains unclear.)

92 "On this point, there was a big difference between Sartre and myself. It seemed to me miraculous to have pulled away from my past, to be self-sufficient, making my own decisions; I had won my autonomy once and for all; nothing could take that away. As for Sartre, he was simply reaching the stage of a man's existence that he had long foreseen with disgust; he had lost the irresponsibility of early youth and was entering the detestable universe of the adults. His independence was in danger. First, he would be constrained for eighteen months to a soldier's life; then the professoriate lay in wait." [Sur ce point, il y avait une grande différence entre Sartre et moi. Il me semblait miraculeux de m'être arrachée à mon passé, de me suffire, de décider de moi; j'avais conquis une fois pour toutes mon autonomie: rien ne me l'ôterait. Sartre, lui, ne faisait qu'accéder à un stade de son existence d'homme qu'il avait depuis longtemps prévu, avec dégoût; il venait de perdre l'irresponsabilité de la première jeunesse; il entrait dans l'univers, détestable, des adultes. Son indépendance était menacée. D’abord, il allait être astreint à dix-huit mois de vie militaire; ensuite le professorat le guettait ( $F A$ 29-30).] Beauvoir would also explain his later episode of hallucinatory depression along the same lines (FA 243-45).

93 As we know from Three Guineas, there are ways full citizenship can be constraining, especially in wartime, ways from which women (because they are not full citizens) are ironically free.

94 So, at the founding moment of "situation," we find, not "Woman," but an intersectional account. What has been taken as an "orientalist" perception of "differences" results from not wanting to generalize her own position.

95 One could understand Beauvoir's initial hesitation to write a book about women in the same light: with respect to her own situation, being a woman did not seem all that interesting - it hadn't made much of a difference to her own life chances; but the situation of women in the world, yes, she could write about that. See FCh 1:135-36 and Kruks, "Living on Rails." 
Without some way of distinguishing between the different situations of different women, Beauvoir would have been trapped within an early Sartrean position of voluntarism, which could only have led to blanket victim-blaming and/or the rather, I want to say American, individual solution: I did it, what's the matter with you? (Why don't you lean in?) By deploying the figure of the "harem woman," Beauvoir is able to avoid blaming all women for not having practically emancipated themselves in the way she herself has done. Far from being a carefree and unconscious expression of European bourgeois superiority, it is an admission of privilege, and a refusal to let her own situation stand for the situation of all women, let alone all people. It is as if she were saying to Sartre, "sure, you and I can do it-but that doesn't mean everyone can, and a purely theoretical abstract freedom is actually not much use to people who are actually suffering." ${ }^{\prime 96}$

Markowitz says, "Although The Second Sex, written soon after, may equivocate somewhat on the matter," and then proceeds to take the Pour une morale de l'ambiguité passage as "Beauvoir." But as we saw, Beauvoir professed herself very dissatisfied with Pour une morale de l'ambiguité, by reason of its abstraction: "It was absurd to pretend one could define an ethics independent of social context." ${ }^{97}$ And it does seem fair to grant theorists the right to evolve in their thinking. Let's see if she did any better in The Second Sex.

The most familiar reference to the "harem" in The Second Sex occurs in the introduction, in a phrase that recalls the conversation she had with Sartre during his leave; it comes in the discussion about the difference between happiness and freedom.

But we do not confuse the idea of private interest with that of happiness. That is another point of view one often comes up against: aren't women of the harem happier than a woman voter? Isn't the housewife happier than the woman worker? It is not easy to know what the word "happy" really means, still less what authentic values might be behind it. There is no way to measure the happiness of others, and it is always easy to call "happy" the situation one wishes to impose on them.... ${ }^{98}$

96 See Moynagh, "Beauvoir on Lived Reality," 16-17; Kruks, "Living on Rails."

97 "Il était aberrant de prétendre définir une morale en dehors d'un contexte social" (FCh 1:99, FCirc 76, translation altered).

98 “Mais nous ne confondons pas non plus l'idée de l'intérêt privé avec celle de bonheur: c'est là un autre point de vue qu'on rencontre fréquemment; les femmes de harem ne sontelles pas plus heureuses qu'une électrice? La ménagère n'est-elle pas plus heureuse que l'ouvrière? On ne sait trop ce que le mot bonheur signifie et encore moins quelles valeurs 
If you diagram this in your head, the harem woman is being set up as a parallel to the housewife (two examples of immanence), the woman voter to the working woman (two examples of transcendence). This has remarkably little to do with the oriental way of life as different from or opposite to "our" way. The contrast, rather, is between two mystifications about women as happy in their subjection, and two examples of women as subjects, as who they are in and for themselves, or at least, could be. And please note that, unlike in Pour une morale de l'ambiguité, the comment about women in harems is attributed speech, and it is speech attributed to an interlocutor with whom she does not agree.

Notice also another change. In the misty conversation with Sartre, the question was whether the harem woman is as free as the abstract human individual. By the introduction to The Second Sex, the abstract human individual has been abandoned — as she said in Pour une morale de l'ambiguïté, he exists nulle part, nowhere. ${ }^{99}$ So the question is whether the harem woman or the housewife is happier than une électrice — a brand-new coinage, by the way ${ }^{100}$ —and the answer is, that's so abstract I won't answer it. In fact, sir, your bad faith in posing this question is so palpable that I will not lower myself to discuss it further.

It is interesting that Markowitz quotes the rather muddy distinction drawn in an early work with which Beauvoir professed herself dissatisfied, rather than this one which (at least to my eyes) is clearer, from a work Beauvoir was willing to stand by until the end of her life. Who exactly is "equivocating" here?

But this is not the end of Arab women in The Second Sex.

Probably only the most obsessive readers will recall a related passage from chapter three of the history section, where the condition of "the Muslim woman, veiled and shut in," is contrasted to the freer life of the "bédouine." This occurs in the course of Beauvoir's unfolding argument about the relationship between the history of women and the history of property. In between the Greeks and the Jews, we find the following:

When family and private patrimonial property remain the uncontested bases of society, women also remain totally alienated. This is what

authentiques il recouvre; il n'y a aucune possibilité de mesurer le bonheur d'autrui et il est toujours facile de déclarer heureuse la situation qu'on veut lui imposer" (DS 1:30-1).

"[U]niversal, absolute Man exists nowhere" [l'Homme universel, absolu, n'existe nulle part (PMA 162, EA 112)]. One reason why the Pour une morale de l'ambiguité passage, as Nancy Bauer and I agree, is really a bit of a mess, is that she could not fully follow through on this insight: she was still wrestling with Hegel's ghost.

100 French women voted for the first time in 1945. Recall the controversy over votes for women, and for "les indigènes," in Pour une morale de l'ambiguïté. 
occurred in the Muslim world. Its structure is feudal, which is to say that there has never emerged a state strong enough to subdue and unite the different tribes; no power holds in check that of the patriarchal chieftain. The religion that emerged when the Arab people were warriors and conquerors displayed the most extreme scorn for woman. "Men rule over women by virtue of the qualities through which God has endowed them with pre-eminence, and because they give women dowries," says the Koran; she has never enjoyed either actual power or mystical prestige. The Bedouin woman does hard labor, she handles the plow and bears heavy loads: in this way she establishes a bond of reciprocal dependence with her husband; she circulates freely with uncovered face. The veiled and confined Muslim woman is still today, at most levels of society, a kind of slave. I recall in a village of cavedwellers in Tunisia an underground hollow where four women were squatting on their haunches: the old wife, one-eyed and toothless, her face horribly ravaged, was cooking some cakes on a small brazier, surrounded by acrid smoke; two other wives, slightly younger but almost as disfigured, were rocking babies in their arms, one of them breastfeeding; a young idol, magnificently decked out with silk, gold and silver, was seated at the loom, knotting strands of wool. As I was leaving this melancholy cavern - the realm of immanence, both womb and tomb-I crossed paths, in the tunnel that led back up to the light, with the Male, dressed in shining white, smiling and sunny. Returning from the market, where he had discussed the business of the world with the other men, he would spend a few hours in this retreat, which was his at the heart of a vast universe to which he belonged, from which it did not separate him. For the old withered women, for the young bride doomed to the same decline, there was no universe apart from the smoky cave from which they only emerge only at night, silent and veiled. ${ }^{101}$

101 "Quand la famille et le patrimoine privé demeurent sans contestation les bases de la société, la femme demeure aussi totalement aliénée. C'est ce qui s'est produit dans le monde musulman. La structure en est féodale, c'est-à-dire qu'il n'est pas apparu d'État assez fort pour unifier et soumettre les différentes tribus: aucun pouvoir ne tient en échec celui du chef patriarcal. La religion qui s'est créée au moment où le peuple arabe était guerrier et conquérant a affiché pour la femme le plus total mépris. 'Les hommes sont supérieurs aux femmes à cause des qualités par lesquelles Dieu leur a donné la prééminence et aussi parce qu'ils dotent les femmes,' dit le Koran; elle n’a jamais détenu ni pouvoir réel ni prestige mystique. La Bédouine travaille durement, elle manie la charrue et porte des fardeaux: par là elle établit avec son époux un lien de dépendance réciproque; elle sort librement, à visage découvert. La Musulmane voilée et enfermée est encore aujourd'hui dans la plupart des couches de la société une sorte d'esclave. Je me rappelle dans un village troglodyte de Tunisie une caverne souterraine où quatre femmes étaient accroupies: la vieille 
Now, some may wish to debate Beauvoir's reading of the Koran, just as some would balk at her readings of the Old and New Testament, which are just as negative if not more so. ${ }^{102}$ The description of strong tribes and weak states probably makes more sense for some places and times than for others. And for the twentieth century, there is now available a wide variety of emic accounts of Muslim women's seclusion, which present a variety of opinions: many of them don't mesh with this one, though some do, in whole or part. ${ }^{103}$ But given that

épouse borgne, édentée, au visage horriblement ravagé, faisait cuire des pâtes sur un petit brasier au milieu d'une âcre fumée; deux épouses un peu plus jeunes mais presque aussi défigurées berçaient des enfants dans leurs bras: l'une d'elles allaitait; assise devant un métier à tisser une jeune idole merveilleusement parée de soie, d'or et d'argent nouait des brins de laine. En quittant cet antre sombre-royaume de l'immanence, matrice et tombeau-j'ai croisé dans le corridor qui montait vers la lumière le mâle vêtu de blanc, éclatant de propreté, souriant, solaire. Il revenait du marché où il avait causé avec d'autres hommes des affaires du monde; il passerait quelques heures dans cette retraite qui était sienne au cœur du vaste univers auquel il appartenait, dont il n'était pas séparé. Pour les vieillardes flétries, pour la jeune mariée vouée à la même rapide déchéance, il n'y avait pas d'autre univers que la cave enfumée d'où elles ne sortaient qu'à la nuit, silencieuses et voilées" ( $D S$ 1:139-40).

102 The Koran is briefly mentioned three times; the New and Old Testament are discussed voluminously, in many sections. The same proportion holds for Islam generally. For instance, when making a general argument that the transcendence offered to women by religion is a mystification, she notes that "[a]mong others, for Jews, Muslims, and Christians, man is the master by divine right" [Entre autres chez les Juifs, les mahométans, les chrétiens, l'homme est le maître par le droit divin $\left(D S_{2: 514}\right)$ ]. But in the page of condemnation that follows to illustrate the point, her examples are all drawn from Catholicism. Should we complain about the negative attitude toward Islam, since there are versions of Islam that would not support this view? but there are also more woman-friendly forms of Judaism and Christianity than Beauvoir ever acknowledges. Or, should we object that the treatment of the three traditions is uneven, and demand "equal time" for other traditions? That might make sense, if one disregarded how unrelentingly negative the discussions of the Western traditions are. Christianity is described as promising women greater freedom in theory, but then instantly taking it away and making things worse for women (and everyone) by its antagonism to sexuality and to the body. As I said above about the attention paid to bourgeois women: It is, I agree, important what people talk about more and what they talk about less, or don't talk about, but not to the point where we should ignore what they say.

103 See Andrea Duranti, "Becoming 'Woman' in the Muslim World: Echoes of Simone de Beauvoir's Thinking." Duranti references the work of Assia Djebar, Fatima Mernissi, Leila Marouane, Malika Mokeddem, Azar Nafisi, and Shirin Ebadi; his strongest example, to my mind, is Nawal El-Saadawi, whose Woman at Point Zero is a paradigmatic existentialist novel, and whose account of the transition to Islam in the book that was translated as The Hidden Face of Eve parallels Beauvoir's account. I would add Marnia Lazreg to his list (see discussion below). 
Beauvoir's account was written in the 1940s, and that her sources appear to have been limited, I want to draw attention to several points.

First, the Arab world is not handled differently from other traditions or parts of the world. It is offered as an example, among others, of her general point that women's status tracks with questions of private property. What follows this passage also tracks a similarity rather than a difference: "The Jews of Biblical times had more or less the same customs as the Arabs. The patriarchs were polygamous."104 A bit later, speaking of fourth-century Athens-the cradle of Western philosophy—she says that "there was no great difference between the gynaeceum and a harem," and details the iniquities of the Athenian system of inheritance-"the epikleros was not a female heir but only a machine to procreate a male heir."105

The customs of the Greeks are very similar to Oriental ones; however, they do not practice polygamy. No one knows exactly why.... [T] he reality was that the Greek citizen still enjoyed all the comforts of polygamy, since he could find ways to satisfy his appetites with the prostitutes of the city or the women servants of the gynaeceum itself. "We have hetairas for spiritual pleasures," says Demosthenes, "pallakes for sensual pleasure, and wives to give us sons." ${ }^{106}$

Second, she speaks to differences between Arab women, based on different relations to labor and property - the distinction between the "bédouine" and the shut-in woman is strikingly similar to the distinction between the French peasant and the French bourgeoise as I discussed it earlier. The "hole" in which the Muslim women live is the "realm of immanence," a term that in the second volume will be mainly associated with the bourgeois apartment inhabited by the miserable "femme d'intérieur." ${ }^{107}$ Moreover, Beauvoir's is a realist, materialist

104 "Les juifs de l'époque biblique ont à peu près les mêmes mœurs que les Arabes. Les patriarches sont polygames" ( $D S$ 1:140).

105 "[L]'épiclère n'était pas héritière mais seulement une machine à procréer un héritier" (DS 1:145).

106 "Les mœurs des Grecs demeurent très proches des mœurs orientales; cependant ils ne pratiquent pas la polygamie. On ne sait pas exactement pourquoi.... [E]n vérité, le citoyen grec demeurait agréablement polygame puisqu'il pouvait trouver chez les prostituées de la ville et chez les servantes du gynécée l'assouvissement de ses désirs. 'Nous avons des hétaïres pour les plaisirs de l'esprit, dit Démosthène, des pallages pour le plaisir des sens, et des épouses pour nous donner des fils"' (DS 1:143-44).

107 Beauvoir's use of the word "troglodyte" at first gave me pause (I've heard it used as an insult for an uneducated or overly conservative person). But the French word turns out to mean simply, "dwelling in caves": "Troglodyte: n.m. (du gr. trôglê, trou, et duein, entrer). 
account and not eroticized, glamourized, or sensationalized. I mention this because the eighteenth-century orientalist discourses to which Markowitz (drawing on the work of Alain Grosrichard) wants to assimilate The Second Sex were primarily erotic texts, written by and for Western men. The materialist account may, for all I know, be quite inaccurate (it's hard to know what Beauvoir's source would have been). But Arab treatment of women is explained, not by some intrinsic "oriental" difference, but by the persistence of a feudal structure of society. This is not about racializing gender difference. It isn't about race at all.

And there's another way it's not an abstraction: she connects her view to something she saw — not in "the Orient," but in Tunisia—and she is upfront about this. Like the discussion in Pour une morale de l'ambiguité of the serious man's chillingly callous joking about bad-smelling Arab midwives, the appearance in that text of the "Musulmane enfermée au fond d'un harem" was related to something that happened while she was writing it, in the course of a solo trip she took to the Mahgreb. One advance of The Second Sex over Pour une morale de l'ambiguité might seem to be that in the later work she comes out and says so, and just tells the story, abandoning the "empty maxims" 108 of historical or philosophical summary which were responsible for the muddled contortions around the figure of the harem woman in the earlier essay.

She gives an even clearer account of the incident in La force des choses. She'd been traveling in Tunisia, to do some lecturing sponsored by the Alliance Française, but mostly because she wanted to explore, as a tourist, a region she'd only glimpsed on previous trips, particularly the Sahara Desert and its oases.

At Médenine, the promised truck was waiting for me. I was the only passenger. The driver must have known the Matmata road before it was damaged in the war. In two or three places bridges had been blown up, but he managed to ford the wadis and brought me to that strange village where ten thousand people live under the ground. The market-place was a seething mass; nothing but men, draped in snowy burnouses, cheerfully chatting and gossiping; the dark, blue-eyed women, some young and beautiful, but dull-looking, were scattered at the bottom of the shafts which led to the caves; I visited one of these dens. Down the dark, smoky caverns I saw a horde of half-naked children, a toothless old woman, two

Habitant des cavernes. // Nom que donnaient les géographes de l'Antiquité à un peuple qui se plaçaient au sud-est de l'Eygpte. //Oiseau passereau insectivore, nichant dans les trous des murs et des arbres, dans les buissons. (Long. $10 \mathrm{~cm}$ )." Petit Larousse, 1080.

108 "[J]'ai pris beaucoup de peine pour poser de travers une question à laquelle j'ai donné une réponse aussi creuse que les maximes kantiennes" (FCh 1:99, FCirc 76). 
neglected-looking women neither old nor young, and a pretty girl covered with jewelry who was weaving a carpet. As I came back up into the light, I passed the master of the house returning from the market, dazzling in his white burnous and gleaming with health. I pitied my sex. ${ }^{109}$

Now, in the memoir this clearly marks what we could call a moment of solidarity-“J'ai plaint mon sexe": plaindre can mean to pity, or it can mean, to sympathize. It's not that she thinks she is the same as they are-she's clearly not-but that there's a point of connection. (There are many differences, but nonetheless some similarities.) The moment of solidarity does not explicitly appear, however, in either Pour une morale de l'ambiguité passage or the passage in The Second Sex, though some readers seem to see it there.

Myself, I don't see this quick moment of imaginative sympathy as sufficient to demonstrate either that Beauvoir saw with "Western eyes," or that she didn't. But it's interesting that in the wider context of Laforce des choses, the encounter is surrounded by a distaste (as yet only mild) for the behavior of the French in the Maghreb. ${ }^{110}$ She met some quite odious "colons," and also some who were more critical of the French presence, including her Alliance Française hosts, "M. and Mme. E."; she also met some "modernized" Tunisian women.

The E.s regarded French policy in Tunisia as clumsy; they were in favor of a rapprochement between the French and Moslem middle classes. At their house I met Tunisian women dressed, made up, groomed and scented just like Parisiennes; they no longer wore veils except in the morning, to go to market; they were thirsty for freedom. Among the men, the young ones were in agreement with them; they resented having their fathers impose wives on them who were ignorant and unenlightened. No one

109 “A Médenine, le camion promis m'attendait. J'étais l'unique passagère. Le chauffeur devait reconnaître la route des Matmata endommagée par la guerre. En deux ou trois endroits des ponts avaient sauté, mais il réussit à franchir les oueds et m’amena jusqu'au singulier village où dix mille personnes habitent sous terre. La place du marché grouillait; rien que des hommes, drapés dans des burnous neigeux, bavards et joyeux; les femmes, brunes, aux yeux bleus, parfois jeunes et belles, mais l'air morne, étaient disséminées au fond des puits sur lesquels donnaient des grottes; j'ai visité un de ces antres: dans de sombres cavernes enfumées, j’ai vu une marmaille demi-nue, une vieille édentée, deux femmes entre deux âges, mal soignées, et une jolie fille couverte de bijoux qui tissait un tapis. En remontant vers la lumière, j'ai croisé le maître du logis qui revenait du marché, resplendissant de blancheur et de santé. J'ai plaint mon sexe" (FCh 1:86, FCirc 66, translation altered).

For the whole account of that trip, see FCh 1:81-9, FCirc 62-8. 
had anything to tell me about the Franco-Tunisian situation in general, and I did not question them too closely. ${ }^{111}$

Perhaps the encounter with these "évoluées" accounts for the phrase "at most levels of society" in the sentence I quoted above: "The veiled and confined Muslim woman is still today, at most levels of society, a kind of slave." The women confined to the cave do not necessarily stand in her mind for "the Arab world," or at least, they do not stand alone in that. But as she describes that particular trip in the passage from La force des choses, any nascent social critique is still subordinated to the adventure of discovering a foreign land. It is not until the next trip that she will declare the old sort of tourism no longer possible. ${ }^{112}$

111 "Les E. trouvaient maladroite la politique de la France en Tunisie; ils souhaitaient un rapprochement entre les bourgeoisies française et musulmane. Je rencontrai chez eux des Tunisiennes habillées, maquillées, coiffées et parfumées à la parisienne; elles ne portaient plus le voile que le matin, pour aller au marché; elles avaient soif de la liberté. Parmi les hommes, les jeunes étaient d'accord avec elles; ils souffraient de se voir imposer par leur père des épouses ignorantes et mal éveillées. Sur l'ensemble de la question franco-tunisienne, personne ne me renseigna et je n'insistai guère." (FCh 1:83-4, FCirc 64).

Writing after her prise de conscience of the Algerian crisis, Beauvoir undoubtedly saw the problem of French rule more clearly in hindsight, but that is precisely her point: how could I not have noticed this? The overall arc of La force des choses documents the path toward greater awareness.

112 "At last I set out with Sartre for Algeria; we wanted sun, we loved the Mediterranean; it was a vacation, a pleasure trip; we would go touring, write, talk. One day Camus had said: 'happiness exists, and it's important; why refuse it? You don't make other people's unhappiness any worse by accepting it; it even helps you to fight for them. Yes,' he had concluded, 'I find it sad the way everyone seems to feel ashamed of feeling happy nowadays.' I agreed with him completely and the first morning I looked out of my room in the Hôtel SaintGeorges at the blue sea with a light heart. But that afternoon we walked around the Casbah, and I realized that tourism, as we had practiced it in the old days, was dead and buried; what had been picturesque before no longer seemed so: what we encountered now in these streets was misery and bitterness....

But Camus, now that I thought it over, had put the question badly; we weren't refusing to feel happy, we just couldn't." [Enfin, je m'embarquai avec Sartre pour l'Algérie; nous souhaitions du soleil, nous aimions la Méditerranée; cétait des vacances, un voyage d'agrément: nous nous promènerions, nous écririons, nous causerions. Un jour, Camus nous avait dit: "Le bonheur, ça existe, ça compte; pourquoi le refuser? En l'acceptant, on n'aggrave pas le malheur des autres; et même, ça aide à lutter pour eux. Oui, avait-il conclu, je trouve regrettable cette honte qu'on éprouve aujourd'hui à se sentir heureux." J'étais bien d'accord, et de ma chambre de l'hôtel Saint-Georges, le premier matin, je regardai gaiement le bleu de la mer. Mais l'après-midi nous nous promenâmes dans la Casbah et je compris que le tourisme, tel qu'autrefois nous l'avions pratiqué, était enterré; le pittoresque s'était décomposé: ce que nous rencontrions dans ces ruelles, c'était la misère 
But in The Second Sex, the concreteness and presentness of the cave example also raises a problem: what is it doing in the history chapter? What century are we in? Are we talking about time or about place?

In fact this is part of a larger problem, which is partly (though only partly) due to Beauvoir's (inconsistent) use of the "historical present" tense to narrate events which are clearly long past, such as Persian and Babylonian laws of inheritance and the behavior of Old Testament patriarchs and fourth-century Athenians. ${ }^{113}$ The problem begins in the sections on "prehistory," and continues as she struggles to account for the transition to patriarchy, not from "matriarchy" (she knows quite well and says that, pace Engels and the "élucubrations" of Bachofen, there was never any such thing), but from ... well, from whatever human life was like before a settled relationship to property cemented men's power over women and children, as part of consolidating their power over other sorts of objects and dominating the natural world.

What gets tricky is that some of this "before" is documented by reference to the life of "tribes" who persisted in that "earlier" way of life long enough for anthropologists to study them in the nineteenth and twentieth centuries, and for Lévi-Strauss to synthesize those findings into a general structuralist account of How Culture Works. An excellent piece by Françoise Héritier, teasing out the strands in these early "Histoire" chapters, establishes the difficulties Beauvoir had in fitting together what she had learned from Lévi-Strauss with a prior strain of thought Héritier describes as "évolutionniste," a term which describes most of what Beauvoir would have found in the Bibliothèque nationale and in the library of the Musée de l'homme.114 Or rather, the piece establishes

et la rancœur.... Mais Camus, réflexion faite, avait mal posé la question; nous ne refusions pas de nous sentir heureux, nous ne le pouvions pas (FCh 1:228, FCirc 173).]

113 Beauvoir's use of tenses is inconsistent, to the point where I've given up the attempt to analyze it fully. What I can say is that some of what is most troubling in the history chapters in terms of orientalism or evolutionism does involves tense shifts which makes it unclear-Beauvoir makes it unclear (let me be clear) — whether the ethnic descriptions do or don't continue to apply.

The same tension can be found in Hegel's Phenomenology: see Robert Pippin, "You Can't Get There From Here: Transition Problems in Hegel's Phenomenology of Spirit." Indeed, that dislocating alternation between historical narrative and cultural description is traceable back as far as Herodotus, the inventor of the "ethnographic present," on whom both Hegel and Beauvoir herself were drawing. But to explore that will require a separate paper.

114 Françoise Héritier, "Les communautés agricoles primitives," in Galster, Le deuxième sexe: Le livre fondateur du féminisme moderne en situation. Another helpful feature of Héritier's 
the difficulties Beauvoir should have had, because as Héritier says, this major contradiction, so clear to us, Beauvoir simply seems not to see.115 It may be helpful to realize that Beauvoir was writing at the very moment of a paradigm shift (reading The Elementary Structures of Kinship right before it was published). Also, as I noted above in my discussion of Leiris, the absence of questions of historical development from the structuralist account is both the greatest strength of that approach, and its blind spot. ${ }^{116}$

chapter is that, while noting that one cannot blame Beauvoir for not knowing what was not known ("Il va de soi qu'on ne saurait reprocher à Simone de Beauvoir de ne pas connaître ce qui était inconnu" [104]), it provides a short account of what is now known, which could be useful in teaching. One must tell the students what is wrong, so it is helpful to tell them also what is right: for instance, that most scholars now acknowledge the role of women in the discovery of agriculture; that Malinowski was wrong to assert that "primitive" societies were unaware of the male role in procreation.

The preceding chapter, by Nicole-Claude Mathieu, on "les hordes primitives," is also excellent. And overall, Galster's collection is a major contribution, both substantively and methodologically, and I regret that it has not been translated. As she explains in her "Présentation," "The Second Sex is undoubtedly the most quoted book in modern feminism. Still, have the 958 tightly-packed pages that make up the two volumes in the Collection Blanche edition always been carefully read? Fifty years after its first publication, it has seemed useful to set in motion a radical return to the text. To create the conditions for a precise and searching reading, we have submitted each chapter of this wide-ranging work - interdisciplinary before there was such a thing — to a researcher particularly welltrained to investigate it." [Le deuxième sexe est sans doute le livre le plus cité du féminisme moderne, mais a-t-on pour autant toujours bien lu les $95^{8}$ pages serrées qui constituent les deux tomes dans la collection blanche? Cinquante ans après sa première publication, il a paru utile d'opérer un retour radical sur le texte. Pour créer les conditions d'une lecture précise et pénétrante, on a soumis chaque chapitre de cette œuvre abondante et pluridisciplinaire avant la lettre à une chercheuse ou un chercheur particulièrement bien armé pour s'en occuper (11).]

115 Héritier, "Les communautés agricoles primitives," 107.

116 Héritier concludes her discussion of the chapter Galster assigned her: "Certainly, Simone de Beauvoir's argumentation is full of errors. Certainly she writes in this chapter a 'grand narrative' which is not true. Certainly, she loses the trail, blinded as she was (as we all are) by images [représentations], in philosophy as much as everyday life, which were (and still are) current and function as though they were certainties. And nonetheless, at the end of the day, there stands a stubborn and illuminating truth. And this is the paradox for $u s$, to say both that the roads she took in this chapter are undoubtedly not the most appropriate ones, but that the picture she paints is nonetheless, in itself, appropriate and fair." [Certes, l'argumentation de Simone de Beauvoir est erronée. Certes elle écrit dans ce chapitre un "grand récit" qui n'est pas véridique. Certes, elle omet des pistes, aveuglée qu'elle fut, comme nous le sommes tous, par des représentations tant philosophiques qu'usuelles qui avaient (ou ont toujours) cours et qui fonctionnent comme des certitudes. Et pourtant, au bout du compte, une vérité est là, éclairante, obstinément posée. Et c'est notre paradoxe à nous, de dire à la fois que les chemins qu'elle a suivis dans ce chapitre n'étaient pas sans 
But to return to the narrower question about how Beauvoir's "Histoire" section approaches people and parts of the world that might be considered "nonWestern": almost all of what she includes (and there's a fair amount) is seamlessly intermingled with what might be considered "Western," in a syncretic, not to say agglutinative, way. For instance, when she tries to clarify the development of agriculture and private property, we find New World Indian, Australian, and Polynesian tribes side by side with Babylonians, Indians from India, Arabs, ancient Celts, and ancient Greeks. Or see her discussion of the so-called Great Mother. ${ }^{117}$

doute les plus appropriés, mais que le tableau qu'elle dresse est cependant, lui, approprié et juste (ibid., 117).]

On the other hand, the criticism of later history sections made by Claudia Opitz ("Moyen Âge et Ancien Régime," 144) that Beauvoir wrongly concluded history had been made exclusively by men, because she uncritically accepted that view from her (male) historical sources—-from Michelet to the early work of the Annales school—must simply be marked, objection sustained. See also Karin Hausen, "De la révolution française aux années 1940," 160-61: "Beauvoir mostly builds up ... an image of the longue durée that is almost outside time. She thus, I think, reinforces representations of the patriarchal order's inertia, its sedimentary force, in ways that work against her political intentions." [Beauvoir ébauche plutôt ... une image de la longue durée presque intemporelle. Elle renforce ainsi, je pense, contre son intention politique, les représentations de la force d'inertie sédimentaire de l'ordre patriarcal.]

117 Beauvoir knows that Bachofen (and therefore Engels) are wrong about the "great historical defeat of the feminine sex": "In truth, this Golden Age of Woman is no more than a myth ... 'Public, or even social, authority always belongs to men,' Lévi-Strauss affirms in the conclusion of his study of primitive societies” [en vérité cet âge d'or de la Femme n'est qu'un mythe ... "Lautorité publique ou simplement sociale appartient toujours aux hommes," affirme Lévi-Strauss au terme de son étude sur les sociétés primitives ( $D S$ 1:122)]. She also knows that goddess-worship, or the fact that women in matrilineal (or other) groups hold apparently high positions, as priestesses or queens, tells us nothing about the actual condition of most women: "It can happen that in a matrilineal society [woman] occupies a high situation, but one must still be aware that the presence of a woman chief, or a queen, at the head of a tribe absolutely does not mean that women there hold power: Catherine the Great's accession to the throne did not in the least alter the lot of Russian peasant women." [Il arrive qu'en régime matrilinéaire elle occupe une situation très haute: encore faut-il prendre garde que la présence d'une femme chef, d'une reine, à la tête d'un tribu ne signifie absolument pas que les femmes y sont souveraines: l'avènement d'une Catherine de Russie n'a en rien modifié le sort des paysannes russes; et il n'est pas moins fréquent qu'elle vive dans l'abjection ( $D S$ 1:123).]

Perhaps here she was also informed by Virginia Woolf's insight (in 1929) that the high status granted women by prized cultural forms such as literature provides no information about women's actual status or life: “[Women] have burnt like beacons in all the works of the poets from the beginning of time.... Indeed, if woman had no existence save in the fiction written by men, one would imagine her a person of the utmost importance; very various; heroic and mean; splendid and sordid; infinitely beautiful and hideous in the 
Capricious, lustful, as cruel as Nature, benevolent but terrifying, [the Great Mother] reigns over the whole Aegean region, over Phrygia, Anatolia, and all Western Asia. She is called Ishtar in Babylon, Astarte by Semitic peoples, and by the Greeks Gaea, Rhea, or Cybele; we find her in the features of Isis in Egypt; the male gods are below her. A lofty idol in the distant realms of heaven or hell, woman on earth is surrounded by taboos, like all sacred beings - she is herself taboo; because of the powers she holds, she is seen as a sorceress or a witch; prayers are offered to her, she sometimes becomes a priestess like the ancient Celtic druidesses; sometimes she takes part in governing the tribe or even governs alone. These remote ages have left us no literature. But the great patriarchal eras preserve in their mythology, monuments, and traditions the memory of a time when women's position was a very high one. From the point of view of women, the Brahman period is a regression from that of the Rig-Veda, and the latter is a regression from the primitive stage that preceded it. Pre-Islamic Bedouin women had much higher status than the Koran accorded them. The great figures of Niobe and Medea evoke a time when mothers took pride in children as in their own property. And in the Homeric poems, Andromache and Hecuba have an importance that classical Greece no longer granted to women hidden in the shadows of the gynaeceum. ${ }^{118}$

extreme; as great as a man, some think even greater. But this is woman in fiction. In fact, as Professor Trevelyan points out, she was locked up, beaten, and flung about the room" (A Room of One's Own, 50-1).

118 "Capricieuse, luxurieuse, cruelle comme la Nature, à la fois propice et redoutable, elle règne sur toute l'Égéide, sur la Phrygie, la Syrie, l'Anatolie, sur toute l'Asie occidentale. Elle s'appelle Ishtar à Babylone, Astarté chez les peuples sémitiques et chez les Grecs Géa, Rhéa où Cybèle; on la retrouve en Égypte sous les traits d'Isis; les divinités mâles lui sont subordonnées. Suprême idole dans les régions lointaines du ciel et des enfers, la femme est sur terre entourée de tabous comme tous les êtres sacrés, elle est elle-même tabou; à cause des pouvoirs qu'elle détient on la regarde comme magicienne, sorcière; on l'associe aux prières, elle devient parfois prêtresse telles les druidesses chez les anciens Celtes; en certains cas elle participe au gouvernement de la tribu, il arrive même qu'elle l'exerce seule. Ces âges reculés ne nous ont légué aucune littérature. Mais les grandes époques patriarcales conservent dans leur mythologie, leurs monuments, leurs traditions, le souvenir d'un temps où les femmes occupaient une situation très haute. Du point de vue féminin, l'époque brahmanique est une régression sur celle du Rig-Véda, et celle-ci sur le stade primitif qui l'a précédée. Les Bédouines de l'époque pré-islamique avaient un statut bien supérieur à celui que leur assigne le Koran. Les grandes figures de Niobé, de Médée, évoquent une ère où les mères considérant leurs enfants comme leur bien propre s'enorgueillissaient. Et dans les poèmes homériques, Andromaque, Hécube ont une 
Soon thereafter, in a similar passage that precedes the infamous footnote by several paragraphs, she speaks in one (long) breath of Aristotle, of Adam and Eve, of Pythagoras, the "laws of Manu" (Wikipedia informs me that this is "a sacred Hindu verse text, a legal code based on the Veda, dating from the second century CE"), Leviticus, the code of Solon, Christian Canon Law, and then the Koran:

Lawgivers, when they organize the oppression of woman, are afraid of her. Of the polyvalent attributes she once enjoyed, what mostly remains is the dangerous side: at one time sacred, she now becomes unclean. Eve, given to Adam as his companion, brought down the whole human race; the pagan gods when they wished to punish mankind invented woman and the first female creature, Pandora, unleashed all the evils that plague humanity. The Other is passivity against activity, diversity destroying unity, matter opposing form, disorder resisting order. Woman is thus doomed to Evil. "There is a good principle which created order, light, and man, and an evil principle that created chaos, darkness, and woman," says Pythagoras. The Laws of Manu define her as a vile being who should be held in slavery. Leviticus puts her in the same category with the beasts of burden owned by the patriarch. Solon's laws confer not a single right upon her. The Roman code puts her in guardianship and proclaims her "imbecility." Canon law considers her "the devil's gateway." The Koran treats her with the most absolute contempt. ${ }^{119}$

importance que la Grèce classique ne reconnaît plus aux femmes cachées dans l'ombre du gynécée" ( $D S$ 1:121).

119 "Organisant l'oppression de la femme, les législateurs ont peur d'elle. Des vertus ambivalentes dont elle était revêtue on retient surtout l'aspect néfaste: de sacrée elle devient impure. Ève donnée à Adam pour être sa compagne a perdu le genre humain; quand ils veulent se venger des hommes, les dieux païens inventent la femme et c'est la premièrenée de ces créatures femelles, Pandore, qui déchaîne tous les maux dont souffre l'humanité. L'Autre, c'est la passivité en face de l'activité, la diversité qui brise l'unité, la matière opposé à la forme, le désordre qui résiste à l'ordre. La femme est ainsi vouée au Mal. 'Il y a un principe bon qui a créé l'ordre, la lumière et l'homme; et un principe mauvais qui a créé le chaos, les ténèbres et la femme,' dit Pythagore. Les lois de Manou la définissent comme un être vil qu'il convient de tenir en esclavage. Le Lévitique l'assimile aux bêtes de somme possédées par le patriarche. Les lois de Solon ne lui confèrent aucun droit. Le code romain la met en tutelle et proclame son 'imbécillité.' Le droit canon la considère comme 'la porte du Diable.' Le Koran la traite avec le plus absolu mépris" (DS 1:134-35). 
The picture is certainly a sweeping one, but it is hardly the particular grand narrative that underwrites a colonialist triumph of the West. Its very grandness makes the opposite point, holding all cultures in equivalence, rather than making a hierarchy or a sequence. (Perhaps it is more of a grand landscape than a grand narrative?) Beauvoir's account differs significantly, not just from Hegel's, but also from what she would have encountered in her own study of Ancient Greece and Rome as an undergraduate, and in preparing for the agrégation. For most of the twentieth century, the opposition between the Ancient Greece and its barbarian Others (Persians, etc.) was routinely and nakedly couched in terms of the politics of nineteenth- and twentieth-century empire; the way she was taught about Ancient Greece would have been part of this attempt to distinguish the font of Western wisdom from the "primitive," or barbarous, parts of the world, in preparing the youth of Europe to take up the "white man's burden" of colonial administration. ${ }^{120}$ Beauvoir does not do this.

Another excellent essay in Galster's collection, by Pauline Schmitt Pantel and Beate Wagner-Hasel, has uncovered the influence of a book by German feminist Lily Braun on Beauvoir's negative view of the Athenians, whom she had been raised to revere as part of her own cultural birthright. ${ }^{121}$ (We've already seen Beauvoir's use of Braun's book in her discussion of prostitution.) $)^{122}$ According to Pantel and Wagner-Hasel, Braun repudiates the idea of matriarchy, and also says: "We are in the habit of considering the Greeks, when compared with the Orientals, as representatives of a remarkably higher civilization. However if one takes the condition of woman as the criterion, one would judge quite differently, for one would find scant progress and even a rather discouraging movement backwards"123 — a formulation very similar to Beauvoir's own.

120 The literature on this aspect of "classical reception" is voluminous, but I would single out Christopher Stray, Classics Transformed, as exemplary.

121 Pauline Pantel Schmitt and Beate Wagner-Hasel, "Lantiquité"; Lily Braun, Die Frauenfrage.

122 It's worth noting that this wonderful book, which Beauvoir credits, seems lost in the mist (or amnesia) that chronically occludes feminist intellectual history, especially when it does not fall neatly into "waves" or national traditions. Many articles exist about Beauvoir and Merleau-Ponty, Beauvoir and Heidegger, a growing number on Beauvoir and Arendt (who was not a feminist, and who hated Beauvoir), but few or none on the relationship of her thought to that of Lily Braun, Colette Audry, Françoise d'Eaubonne, Wollstonecraft, Woolf...

123 "Nous avons l'habitude de considérer les Grecs, par rapport aux Orientaux, comme les représentants d'une civilisation remarquablement plus élevée. Si cependant on prenait la condition de la femme comme critère, on jugerait tout différemment, car on trouverait à 
So is Beauvoir writing a progress narrative or isn't she? Well, if by "progress narrative" we mean the Hegelian story of unbroken progress from darkness to light and from East to West, no. ${ }^{124}$ For instance, at the same time- the fourth century ВСЕ-Sparta was better for women and Athens was worse, because the laws of property, and the relation between the family and the State, were different. The "Brahmans" are found wanting in comparison with the Vedas, not in comparison to what was happening in "the West" (or the proto-West) in the same era. And, as we saw above, things "in the West" can stagnate, or go backwards, or leave some women better off and other women worse off. ${ }^{125} \mathrm{But}$

peine quelques progrès et même un mouvement de recul assez pénible" (Pantel and Wagner-Hasel, "L'antiquité," 128).

As Pantel and Wagner-Hasel note, one sign of the prominence of Greek and Roman classics in her education was that at the oral examination for the agrégation she would have been given an untranslated Greek text to comment on. (This according to Maurice Gandillac, who took the same exam.) They also point to a rare footnote in The Second Sex, in Beauvoir's rather Herodotean account of Persia and Egypt: "This account is taken from Clément Huart, La Perse antique et la civilisation iranienne." Pantel and Wagner-Hasel note that this book was part of a series called "l'évolution de l'humanité," which they discovered was kept in the general reference section in the reading room of the Bibliothèque nationale.

Further discussion of this topic must wait. But it would be valuable also to attend to the literary side of Beauvoir's education in the "classical tradition," to the remarkably quick progress she made in overcoming the deficiencies of her preparation at the Greekless Cours Desir, and to her use, as another source for The Second Sex, of an English book, James Donaldson's Woman: Her Position and Influence in Ancient Greece and Rome, and Among the Early Christians (1907). We are indebted to Constance Borde and Sheila Malovany-Chevallier for having identified (on p. 61 of their translation) this book, which Beauvoir alludes to rather cryptically at $D S$ 1:95. For a detailed reading of Beauvoir's education and its historical context, see Moi, Making of an Intellectual Woman, part 1 , chapter 2.

124 If it is permissible to speak of arguments that "haunt" a text, but are not actually in the text, this whole section is haunted by the awareness that if we bring women into the picture, Hegel's view of history cannot be right. But I don't think it's permissible to speak of such things, I think it's slightly mad, actually. And in any case, she had already found and stated many other good reasons not to agree with Hegel's theory of history as the progressive triumph of Geist.

125 In the more modern parts of the history, we could say her point was largely to prove the nearly "unbroken subjection" of women in the West also: despite some complexity, and even some dissenters, the codes of chivalry didn't "break" it, neither did the French Revolution, the Enlightenment, or the rise of the bourgeoisie; it was not until the industrial revolution put women to work that they gained a measure of control over their own destinies, and even then, as we have seen, the condition of women workers was lamentable. The "progress" Beauvoir documents does show up in legal reform toward the end of the nineteenth century, and then in her history of suffrage movements. As she reaches the present time of writing, she notes that, with the resolutions passed by the UN Commission 
insofar as Beauvoir judges that some cultures, at some eras, are better for women and others are worse, one must say yes, "progress" is very much at issue here, ${ }^{126}$ even though her overall thesis is that the progress has often been more illusory than real, that the promise has not been fulfilled. At the end of the history section: "The fact that controls women's condition today is the stubborn survival of the most antiquated traditions in the new civilization that is beginning to take shape." ${ }^{\prime 27}$

How then do we interpret that "long, unbroken subjection" footnote, which does not jibe particularly well with anything that is before or after it? Well, here's my imaginative reconstruction: "I've done the best I possibly can to include everything that's in the library: if I don't find a way to leave something out, I'm never going to finish this book."

Or maybe I'm just projecting.

So much for Beauvoir's "history." But the second passage on which Markowitz rests her claim occurs in the myth section, and actually, most of what hurts our ears about "the Orient" occurs there. As I've already said, everything in the three chapters of the myth section must be understood as imaginary, powerful but/because imaginary: the point is to investigate what we can tell about people - about men, really - from how they imagine Woman. As I said above, it's important not to be misled by Beauvoir's long ironic paraphrases in style indirect libre. Lori Marso puts this very nicely when she speaks of Beauvoir's "mimicking of male voices," which can make it hard to be sure what she is or isn't "endorsing." 28 Beauvoir sometimes talks about Scheherazade as though Scheherazade really existed. But she talks in the same way about Eve, and Pandora, and Stendhal's character Mlle. de la Mole. Like so much else in The

on the Status of Women, "[i]t would seem that the game has been won" [[i]l semble donc que la partie soit gagnée $(D S$ 1:220)]. And yet abstract rights do not guarantee real equality ("les droits abstraits, nous venons de le dire, n'ont jamais suffi à assurer à la femme une prise concrète sur le monde: entre les deux sexes, il n'y a pas aujourd'hui encore de véritable égalité," $D S$ 1:228).

126 Hausen ("De la révolution française aux années 1940," 164) points out Beauvoir's belief, following Engels and Marx, in the "march of history" advanced, as if inevitably, by means of the "evolution of techniques" in the industrial revolution-in spite of what she shows about the immiseration of women workers in factories.

127 "Le fait qui commande la condition actuelle de la femme, c'est la survivance têtue dans la civilisation neuve qui est en train de s'ébaucher des traditions les plus antiques" ( $D S$ 1:231).

128 Lori Marso, Politics With Beauvoir: Freedom in the Encounter, 27. 
Second Sex, the images of the East are for the most part literary rather than "factual," and Beauvoir knows this. When she writes that "only the sultan of the Thousand and One Nights has the power to behead mistresses when dawn takes them from his bed,"129 she is describing a male fantasy of sexual conquest, and a Western one at that.

Where the history section shifted awkwardly between static synchronic comparison and diachronic narrative, the method of the myth chapters is deliberately ahistorical, structured by topic and theme. Josette Pacaly calls it a "light-hearted journey," full of "oscillations" and "meanderings." "Beauvoir invites us on a vast-ranging tour of the world." 130 The discussion travels as easily in time as in space, bringing data from very different cultures and eras into non-hierarchical parallel, mingling information about "primitive societies" from Lévi-Strauss, Malinowksi, etc. with rural and urban western customs, poetry and other "high" literature, and "I heard a man say one day." Speckled amid this profusion of examples are some references to "les Indes" and to Islam, which are in no way labelled as worse and sometimes come off better. Discussion of women in the "Orient" is always embedded in long paragraphs that discuss the oppression of women not in the Orient. This intermingling makes precisely the opposite point from what is claimed to be orientalism, a stark opposition between two worlds. (Indeed, in all this welter of detail it is hard to keep track of what "the Orient" could really mean: there are many more parts of Beauvoir's world than just two. $)^{131}$

129 "[S]eul le sultan des Mille et une nuits a le pouvoir de trancher la tête de ses maîtresses dès que l'aube les retire de son lit" ( $D S$ 1:271).

130 "[U]n parcours allègre, plein d'allers et retours; on pense à la dialectique que Pascal définissait comme un perpétuel renversement du pour au contre, où à la méthode progressive-régressive de Sartre; chemin faisant Beauvoir parle d' 'oscillations,' de 'méandres compliqués'... Beauvoir ... nous invite ... à un immense périple à travers le monde..." (Pacaly, "La femme et les mythes," 172-73). Pacaly quotes $D S$ 1:242: "It is always difficult to describe a myth: it won't let itself be grasped or defined, it haunts consciousnesses without ever being posed in front of them like a fixed object. [The myth of Woman] is so changeable, so contradictory, that it takes a while to see it as a unified whole: Dalila and Judith, Aspasia and Lucretia, Pandora and Athena, woman is at the same time Eve and the Virgin Mary." [Il est toujours difficile de décrire un mythe; il ne se laisse pas saisir ni cerner, il hante les consciences sans jamais être posé en face d'elles comme un objet figé. Celui-ci est si ondoyant, si contradictoire qu'on n'en décèle pas d'abord l'unité: Dalila et Judith, Aspasie et Lucrèce, Pandore et Athéné, la femme est à la fois Ève et la Vierge Marie.]

131 One might ask oneself whether, in the 1940s, the Jews of the Old Testament counted as Orientals or not; right-wing French (and, for that matter, British) writers continued to describe modern Jews as "Asiatic," and they didn't mean this as a compliment. But drawing such distinctions do not seem to interest Beauvoir. 
For instance, in talking about how the worship of nature as female survives long after the Great Mother has been "dethroned," Beauvoir refers in one swoop to Goethe's second Faust, William Blake ("the matron Clay"), "un prophète indien" who tells his disciples not to plow the Earth because this would harm their "mother"; this last is also true, she says, of "les Baija" who live "en Inde centrale." In the next sentence, we have Aeschylus and Sophocles; "the beloved of an Egyptian song declares, 'I am the Earth!"; 132 "in the Islamic texts woman is called 'a field ... the grape-bearing vine"; $; 33$ then we hear about St. Francis of Assisi ... then Michelet.... ${ }^{134}$ She shows a similar eclecticism when it comes to taboos and fears about menstruation: in the list of customs that isolate girls at menarche (sometimes she is forbidden to touch her own body, sometimes she is forbidden to touch food, etc.) it is hard to tell exactly when Beauvoir slides from Lévi-Strauss to Leviticus, which, she says, views the "impurity" of menstruation in the same way it views the impurity of gonorrhea. ${ }^{135}$ Among those who are cited as thinking the presence of a menstruating woman might spoil food or drink or other products, we find Pliny, "un vieux poète anglais,"136 the British Medical Association Journal in 1878 (meat), the sugar refineries of the North (?) at the beginning of the century, ${ }^{137}$ and this: "In Saigon, women are

132 "La bien-aimée d'une chanson égyptienne déclare: 'Je suis la terre!" ( $D S$ 1:245).

133 "Dans les textes islamiques la femme est appelée 'champ ... vigne aux raisins"” ( $D S$ 1:245).

$134 D S$ 1:245.

135 Menstruation taboos can be ambivalent, and power can heal as well as harm: "still today some Indians" protect their boats with "a wad of fibers soaked in menstrual blood," young girls in ancient Greece dedicated their stained linen to Astarte, and so on (DS 1:250).

136 "An old English poet" ( $D S$ 1:251). I and several friends spent a pleasurably procrastinatory morning attempting to identify the source of the lines she (mis)quotes as "Oh! menstruating woman, thou'st [sic] a fiend / From whom all nature should be screened." He may have been the seventeenth century Abraham Cowley, who lived through the English Civil War and died shortly after the Restoration, but we couldn't quite verify this. See Lesel Dawson, "Menstruation, Misogyny, and the Cure for Love." It seems very likely that Beauvoir encountered these lines in Ellis, Studies in The Psychology of Sex, Volume 1: The Evolution of Modesty, The Phenomena of Sexual Periodicity, Autoeroticism (1926), where they appear on page 331, also without the poet's name. Ellis's volume is itself a dizzyingly syncretic and bizarrely comprehensive compendium of received ideas on the topics in the subtitle, drawn indiscriminately from science, ethnography, literature, and commonplace. Unlike Beauvoir, Ellis seems not to have known that what he was compiling was a book of myths, but his style may have had some influence on hers.

137 "These beliefs have continued quite forcefully right until today. In 1878, a member of the British Medical Association sent in to the British Medical Journal as article in which he declared: 'It is an unquestionable fact that meat becomes rotten when it is touched by menstruating women'; he claimed to be personally acquainted with two instances where hams had been spoiled under those circumstances. At the beginning of this century, in 
not employed in opium factories: because of their periods, the opium goes bad and becomes bitter. These beliefs survive in many areas of the French countryside." 138 And apparently they also survive in French scientific writing, as a hilarious footnote describes. ${ }^{139}$ (Pacaly calls this a "sottisier réjouissant!," a delightful compendium of stupidities.) $)^{140}$ There follows a long quotation

the refineries of the North, a regulation forbade women from entering the factory when they were suffering from what the Anglo-Saxons call 'the curse,' because the sugar would turn black." [Ces croyances se sont perpétuées jusqu'à nos jours avec beaucoup de force. En 1878, un membre de l'Association médicale britannique a fait une communication au British Medical Journal où il déclarait que: "C'est un fait indubitable que la viande se corrompt quand elle est touchée par des femmes ayant leurs règles"; il dit connaître personnellement deux cas où les jambons ont été gâtés en de telles circonstances. Au début de ce siècle, dans les raffineries du Nord, un règlement défendait aux femmes d'entrer dans la fabrique quand elles étaient atteintes par ce que les Anglo-Saxons appellent le "curse," la "malédiction": car alors le sucre noircissait (DS 1:251).]

138 "Et à Saigon, on n'emploie pas de femmes dans les fabriques d'opium: par l'effet de leurs règles, l'opium tourne et devient amer. Ces croyances survivent dans beaucoup de campagnes françaises." The passage continues:

"Every cook knows it is impossible to make a successful mayonnaise if she or anyone near her is 'indisposed.' Recently in Anjou an old gardener, after storing the year's cider harvest in a cellar, wrote to his master, 'you must ask the young ladies of the household and female guests not to enter the cellar on certain days of the month, they would keep the cider from fermenting.' The cook, when told of this letter, merely shrugged: that never kept the cider from fermenting, says she, it's only bad for making lard." [Toute cuisinière sait qu'il lui est impossible de réussir une mayonnaise si elle est indisposée ou simplement en présence d'une femme indisposée. En Anjou, récemment, un vieux jardinier, ayant emmagasiné dans un cellier la récolte de cidre de l'année, écrivait au maître de la maison: "Il faut demander aux jeunes dames du logis et aux invitées de ne pas traverser le cellier à certains jours du mois: elles empêcheraient le cidre de fermenter." Mise au courant de cette lettre, la cuisinière haussa les épaules: “Ça n’a jamais empêché le cidre de fermenter, dit-elle, c'est pour le lard seulement que c'est mauvais..." (DS 1:251-52).]

139 "The question of whether these prejudices have any basis in fact is still discussed today. The only fact adduced in its favor by Dr. Binet is an observation by Schink (cited by Vignes). Schink supposedly saw flowers wilt in the hands of a servant who had her period; some yeast cakes prepared by that woman supposedly only rose three centimeters instead of the five centimeters they normally reached. At any rate this data is quite meagre and sketchy when one compares the universal scope of such beliefs, whose origin is clearly mystical." [On discute encore aujourd'hui la question de savoir s'il y a quelque fondement à ces préjugés. Le seul fait que rapporte en leur faveur le docteur Binet est une observation de Schink (citée par Vignes). Schink aurait vu des fleurs se faner entre les mains d'une servante indisposée; les gâteaux à la levure fabriqués par cette femme n'auraient monté que de trois centimètres au lieu des cinq centimètres qu'ils atteignaient normalement. De toute façon ces faits sont bien pauvres et bien vaguement établis si on considère l'importance et l'universalité des croyances dont l'origine est évidemment mystique $\left(D S_{1: 252}\right)$.]

Josette Pacaly, “La femme et les mythes," 173. 
about menstrual taboos among the Chago, cited by Lévi-Strauss, supported by a parallel among "the Aleutians"; again Leviticus; then the French romantic poet Alfred de Vigny, whom Beauvoir, like every French child, would have studied at school. A page later, Leviticus is once more given equal weight with the laws of Manu, and the discussion ends with the Oedipus complex. ${ }^{141}$

Women can help the community maintain a connection with the mysterious powers of the natural world: "still today, among the Bedouins, among the Iroquois, [woman] assures the fertility of the fields," and in Ancient Greece she was Pythia and prophetess. ${ }^{142}$ Beauvoir has a great deal to say about myths of Virginity, whose power unites dread and desire: here we find Venus emerging from the water ("sortie toute neuve de l'eau"), Genesis, and the laws of Manu, in the same paragraph as a drawing by André Masson, further illuminated by a footnote to Rabelais. ${ }^{143}$ Nor is it purely a case of "Western eyes" looking at "Eastern" matters.

Marco Polo asserted about the Tibetans that "none of them wanted to take a virgin girl as wife." A rational explanation has sometimes been given for this refusal: the man does not want a wife who has not yet aroused masculine desires. El-Bekri, the Arab geographer, speaking of the Slavic peoples, notes that "if a man gets married and finds that his wife is a virgin, he says, 'If you were worth something, men would have loved you and one of them would have taken your virginity."'144

I have not succeeded in figuring out who El-Bekri (or Al-Bekri) might have been, but his appearance certainly reverses the ethnographic lens. Beauvoir's

\footnotetext{
$141 \quad D S$ 1:254.

142 "Elle assure encore aujourd'hui chez les Bédouins, chez les Iroquois, la fécondité des champs; dans la Grèce antique, elle entend les voix souterraines" ( $D S$ 1:255).

143 "Woman is like the field in which man sows the seed,' say the Laws of Manu. A drawing by André Masson shows a man, hoe in hand, cultivating the garden of the female genitals." ["La femme est comme le champ et l'homme comme la semence," disent les Lois de Manou. Dans un dessin d'André Masson on voit un homme, une pelle à la main, qui bêche le jardin d'un sexe féminin $(D S$ 1:256).]

144 "Selon que l'homme se sent écrasé par les puissances qui le cernent, ou qu'il se croit orgueilleusement capable de les annexer, il refuse ou réclame que son épouse lui soit livrée vierge.... Marco Polo affirmait des Tibétains 'qu'aucun d'eux ne voudrait prendre pour femme une fille qui serait vierge.' On a parfois expliqué ce refus d'une manière rationnelle: l'homme ne veut pas d'une épouse qui n'a pas déjà suscité des désirs masculins. Le géographe arabe El Bekri, parlant des Slaves, rapporte que 'si un homme se marie et trouve que sa femme est vierge, il lui dit: 'Si tu valais quelque chose, des hommes t'auraient aimée et il y en aurait un qui t'aurait pris ta virginité.' Puis il la chasse et la répudie" (DS 1:256-57).
} 
discussion of virginity myths concludes with mentions of the Valkyries, Joan of Arc, wedding night customs of the "indigènes described by Malinowski," the Brahmans of the Malabar coast, the Ancient Romans, and the Samoans. And "there are still villages in France where the bloody sheet is displayed."145

Now, this syncretic or synoptic mode of inquiry was not Beauvoir's invention, obviously. References make it clear that she has been reading Jung and Bachelard, whose method in such works as L'eau et les rêves may have been influential. ${ }^{146}$ She refers frequently also to the sociologist and sinologist Marcel Granet, and to Georges Dumézil (1898-1986), the founding figure of the discipline of "comparative mythology," who was in many ways a precursor of structuralism. Dumézil studied parallels between Greek, Roman, Indian, and ancient Iranian traditions, and derived what he believed to be a common ideological structure dividing both mythological narratives and social institutions into three "functions": that particular homology has been called into question, but the influence of his method continues to be felt in the crosscultural study of myth. He also apparently supported and influenced both Lévi-Strauss and then Foucault. Beauvoir never mentions the "three functions," but her frequent references to Dumézil's work Mitra-Varuna, and indeed to the "laws of Manu," show that he was an important influence on her thought as well.

What we are dealing with here is not the popularizing universalism of a Joseph Campbell, which strips away cultural particularities and turns every story into the same story. Rather, it is a nuanced and (at least in Beauvoir's hands) somewhat torturous inquiry into both similarities and differences across cultures. Dumézil himself can be criticized for the way he "slices up the world"the phrase is Keith Nightenhelser's ${ }^{147}$-in that he defended the existence of something called "Indo-European culture" and described patterns that (he thought) were found there and not found elsewhere. (And he has been blamed for the rather awful uses to which the idea of "Indo-European culture" was put by the Third Reich, though Didier Eribon and others make strong arguments that this was unfair. $)^{148}$ Beauvoir, however, did not "slice up the world" in that

145 "Il y a encore en France des villages où, le matin des noces, on exhibe devant parents et amis le drap ensanglanté" (DS 1:259).

146 Bachelard's comment in prefacing his own work- "People might be surprised to see a rationalist philosopher devoting such attention to illusions and errors"-could apply to Beauvoir as well. Gaston Bachelard, L'eau et les rêves, 18: "On a pu s'étonner qu'un philosophe rationaliste donne une si longue attention à des illusions et à des erreurs."

147 Personal communication.

148 Didier Eribon, Faut-il brûler Dumézil? See also David Frauenfelder's review of García Quintela, Dumézil: An Introduction, and Hugo Freund's review of C. Scott Littleton, The 
way, or indeed in any way at all: just putting the "laws of Manu" in parallel with Leviticus, as she does repeatedly, shows she's not drawing a distinction between Semitic and Indo-European worlds. Her copious use of Dumézil's examples, detached from the over-arching theory he was using them to support, is yet another example of the "unhooking" we saw with Stekel, Ellis, etc.

Some of what Beauvoir draws from Dumézil, Granet, and other sources for these chapters may be right and some of it is undoubtedly quite wrong. But none of it was even visible to Markowitz because it does not look like what she was combing for: that is to say, it was not part of that orientalizing discourse we are trained to look for and object to. Beauvoir does not speak of "the Orient" when referring to the work of Granet and Dumézil, but rather of other cultures, understood as systems of thought in their own right. There's no distinction drawn between "myth" (them) and "religion" (us): the myths of the Chago and the Greeks are put in parallel with the myths of Christianity, and indeed with the myths created by supposedly "rationalist" thinkers from Pythagoras to Aquinas to the British Medical Association and the man next door. (Perhaps we have forgotten that calling Christianity a "myth," and examining it on the same level as other stories, was once a very radical thing to do.)

Interestingly, the rather awful lines Markowitz quoted about the "insouciant Oriental" are embedded in just such a characteristically syncretic (and tortuous) discussion of the shift toward companionate understandings of marriage, drawing again on Dumézil, where non-Western (as well as Western) examples weigh on the "after" side as well as the before.

In the patriarchal family, feminine magic was deeply domesticated. Woman makes it possible for society to integrate into itself the cosmic forces. Dumézil indicates in his study Mitra-Varuna that, in India as in Rome, there are two ways for male power to affirm itself: in Varuna and Romulus, in the Gandharvas and the Luperques, it is aggression, abduction, disorder, hubris; then woman appears as a being who must be violently assaulted and raped; the abducted Sabine women were sterile, they were whipped with goatskin thongs, dealing violently with violence. But Mitra, Numa, the Brahmans and the flamines, on the contrary, ensured the order and the reasonable equilibrium of society; then the wife is bonded with the husband by a complicated ritual of marriage and, collaborating with him, she assures for him the domination of all the female forces of nature; in Rome, if the flamina dies, the flamen dialis resigns his

New Comparative Mythology: An Anthropological Assessment of the Theories of Georges Dumézil. 
office. It is thus that in Egypt Isis, having lost the supreme power of the Goddess Mother, nonetheless remains generous, smiling, welcoming and kind, the magnificent spouse of Osiris. But when woman appears thus as the associate of man, his complement, his other half, she of necessity possesses a conscience, a soul; he could not depend so intimately on a being who did not participate in the human essence. We have already seen that the laws of Manu promised to the legitimate wife the same paradise as her husband. The more the male becomes individualized and lays claim to his individuality, the more certainly he will recognize also in his companion an individual and a free being. The Oriental careless of his own fate is content with a female [femelle] who is for him an object of pleasure [jouissance]; but the dream of the Occidental, once he rises to consciousness of his own uniqueness, is to be taken cognizance of by another free being, at once strange and docile. ${ }^{149}$

What follows deals with the difference between Greece and Rome, then gets to the main enemy, Christianity, which paradoxically proclaims women's "equality" and then traps her in the duality of Virgin and Whore.

I am not, by any means, arguing that this account is a correct one, or even that it makes sense: the confusion of tenses alone is dizzying. What is the

149 "La magie féminine a été profondément domestiquée dans la famille patriarcale. La femme permet à la société d'intégrer en elle les forces cosmiques. Dans son ouvrage, Mitra-Varuna, Dumézil signale qu'aux Indes comme à Rome, il y a deux manières pour le pouvoir viril de s'affirmer: en Varouna et Romulus, dans les Gandharvas et les Luperques, il est agression, rapt, désordre, hybris; alors la femme apparaît comme un être qu'il faut ravir, violenter; les Sabines ravies se montrent stériles, on les fouette avec des lanières en peau de bouc, compensant par la violence un excès de violence. Mais Mitra, Numa, les Brahmanes et les Flamines assurent au contraire l'ordre et l'équilibre raisonnable de la cité: alors la femme est liée au mari par un mariage aux rites compliqués et, collaborant avec lui, elle lui assure la domination de toutes les forces femelles de la nature; à Rome, si la flamina meurt, le flamen dialis se démet de ses fonctions. C'est ainsi qu'en Égypte, Isis, ayant perdu sa puissance suprême de déesse mère, demeure cependant généreuse, souriante, bienveillante et sage, la magnifique épouse d'Osiris. Mais quand la femme apparaît ainsi l'associée de l'homme, son complément, sa moitié, elle est nécessairement douée d'une conscience, d'une âme; il ne saurait si intimement dépendre d'un être qui ne participerait pas à l'essence humaine. On a vu déjà que les Lois de Manou promettaient à l'épouse légitime le même paradis qu'à son époux. Plus le mâle s'individualise et revendique son individualité, plus aussi il reconnaîtra en sa compagne un individu et une liberté. L'Oriental insouciant de son propre destin se contente d'une femelle qui est pour lui un objet de jouissance; mais le rêve de l'Occidental, quand il s'est élevé à la conscience de la singularité de son être, c'est d'être reconnu par une liberté étrangère et docile" (DS 1:280-81). 
relationship between what the laws of Manu already "promised" (in the imperfect tense), and the Oriental who is seemingly stuck in the ethnographic present? Once again, the problem Héritier identified with the history chapter rears its head. My point is merely that quoting the last two sentences out of context oversimplifies what Beauvoir was doing. As I said above, there is in these chapters no discussion of "the Orient" that is not attached to discussions of the not-Orient; sometimes it is the latter that comes off worse, ${ }^{150}$ but usually questions of comparative judgment vanish in a welter of concrete particulars. The overall point is not about a binary difference, and the effect is the opposite of cultural triumphalism.

Another example: Beauvoir takes a similarly syncretic approach to the question of female beauty:

All the poets of the East and the West [d'Orient et d'Occident] have transformed woman's body into flowers, fruits, birds.... Here too, one would have to cite an entire weighty anthology. ${ }^{151}$

Her citations are drawn from the Song of Songs, Breton, Steinbeck, Colette, "Samivel cited by Bachelard," and the poet Léopold Senghor (1906-2001), négritude's greatest champion, who would later serve as the first president of Senegal. Around this time, Senghor's work was appearing in Présence Africaine (which Les Temps Modernes was strongly supporting); his Anthologie de la nouvelle poésie nègre et malgache came out in 1948, with a preface by Sartre, "Orphée noir" (Black Orpheus). Beauvoir quotes Senghor's lines (beginning "Naked woman, dusky woman! / Ripe and firm-fleshed fruit" [Femme nue, femme obscure! / Fruit mûr à la chair ferme]) in absolute parallel to the others, much as the work of Richard Wright and other theorists of Black experience was appearing alongside her own theoretical work in Les Temps Modernes.

Different cultures, it is true, have different ideals of beauty - and different ideal objects of desire. In her desire to leave nothing out, Beauvoir goes on to say some things that, taken in isolation, are bizarre. In the end, she's going to say, the beauty myth amounts to the same thing, a male fantasy and a mystification, wherever and whenever it is found. But as with other "sandwiches" I've discussed, the road to this conclusion is mined with some troubling bits. So, a

150 For instance, at $D S$ 1:282 we find "la Grande Mère asiatique" contrasted to the Virgin Mary, to the detriment of the latter.

151 "Tous les poètes d'Orient et d'Occident ont métamorphosé le corps de la femme en fleurs, en fruits, en oiseaux. Ici encore, à travers l'Antiquité, le Moyen Âge et l'époque moderne, c'est toute une épaisse anthologie qu'il faudrait citer" ( $D S$ 1:261). 
few pages later she embarks on a general discussion of what we would call "objectification":

when woman is handed over to the male as his possession, what the latter demands is that, in her, the flesh be present in pure facticity. Her body is grasped, not as the radiance of a subjectivity, but as a thing, heavy with immanence; this body does not refer to the rest of the world, it must promise nothing but itself: it must be the ending point of his desire. ${ }^{152}$

So far, so good. But then:

The most naive form of this demand is the Hottentot ideal of the Steatopygian Venus, since the buttocks are the part of the body least supplied with nerves, the part where flesh appears as a given without a destination. The preference of Orientals for fat women is of the same sort; they love the absurd luxury of this adipose proliferation, which no project animates, which has no meaning except to be there. ${ }^{153}$

Wait, what?

So, there is a footnote, which quotes from "Luquet, Journal de Psychologie, 1934, Les Vénus des cavernes,"154 and here is what her footnote quotes:

The Hottentots, among whom steatopygy is neither as fully developed or as constant as among bushwomen, consider this conformation as aesthetically valuable and massage the buttocks of their daughters to develop them. In the same way the artificial fattening of women, a real

152 "[Q]uand la femme est livrée au mâle comme son bien, ce que celui-ci réclame, c'est que chez elle la chair soit présente dans sa pure facticité. Son corps n'est pas saisi comme le rayonnement d'une subjectivité, mais comme une chose empâtée dans son immanence; il ne faut pas que ce corps renvoie au reste du monde, il ne doit pas être promesse d'autre chose que de lui-même: il lui faut arrêter le désir" ( $D S$ 1:264).

153 "La forme la plus naïve de cette exigence, c'est l'idéal hottentot de la Vénus stéatopyge, les fesses étant la partie du corps la moins innervé, celle où la chair apparaît comme un donné sans destination. Le goût des Orientaux pour les femmes grasses est de la même espèce; ils aiment le luxe absurde de cette prolifération adipeuse que n'anime aucun projet, qui n'a d'autre sens que d'être là" ( $D S$ 1:264).

154 I haven't entirely succeeded in tracing this; it would appear to be Luquet, "Les Vénus paléolithiques," but this article is, for some reason, unobtainable. Luquet seems to have been a scholar of paleolithic art: Gunter Berghaus, in New Perspectives on Prehistoric Art, refers to his book "Lart et la religion des hommes fossiles" (1926) and to a 1910 article comparing paleolithic figures to graffiti. 
force-feeding whose two essential methods are immobilization and the copious ingestion of particular foods, chiefly milk, can be found in various parts of Africa. It is still practiced by well-to-do Arab and Jewish citydwellers of Algeria, Tunisia, and Morocco. ${ }^{155}$

This sounds unlikely, doesn't it? But if someone made it up, that someone was not Beauvoir. And what is she doing with this "example"? Her paragraph continues:

Even in civilizations with more subtle sensibility, where notions of form and harmony come into play, a woman's breasts and buttocks continue to be prized because they blossom out and develop in a gratuitous, contingent way. Customs and fashions often work to sever the female body from its transcendence: the Chinese woman with bound feet can scarcely walk; the polished claws of the Hollywood star deprive her of the use of her hands; high heels, corsets, bustles, farthingales, crinolines are intended not just to exaggerate the curves of the female body, but to render it useless. ${ }^{156}$

Once again, she's not saying it's worse, she's not saying it's better, and she's not using the Eastern example as an allegory for the others. She's piling up all the examples she can find, to make a general point that is, I feel, still relevant:

Weighed down by fat, or too slender and delicate to exercise any effort, paralyzed by awkward clothes and by the rituals of propriety, [her body] thus appears to man as his thing. ${ }^{157}$

155 "Les Hottentotes chez qui la stéatopygie n'est ni aussi développée ni aussi constante que chez les femmes bushman considèrent cette conformation comme esthétique et malaxent les fesses de leurs filles dès l'enfance pour les développer. De même l'engraissement artificiel des femmes, véritable gavage dont les deux procédés essentiels sont l'immobilité et l'ingestion abondante d'aliments appropriés, en particulier du lait, se rencontre dans diverses régions de l'Afrique. Il est encore pratiqué par les citadins aisés arabes et israélites d'Algérie, de Tunisie, et du Maroc" (DS 1:264).

${ }_{15} 6$ "Même dans les civilisations d'une sensibilité plus subtile où interviennent des notions de forme et d'harmonie, les seins et les fesses demeurent des objets privilégiés à cause de la gratuité, de la contingence de leur épanouissement. Les coutumes, les modes se sont souvent appliquées à couper le corps féminin de sa transcendance: la Chinoise aux pieds bandés peut à peine marcher, les griffes vernies de la star d'Hollywood la privent de ses mains, les haut talons, les corsets, les paniers, les vertugadins, les crinolines étaient destinés moins à accentuer la cambrure du corps féminin qu'à en augmenter l'impotence" (DS 1:264-65).

157 "Alourdi de graisse, ou au contraire si diaphane que tout effort lui est interdit, paralysé par des vêtements incommodes et par les rites de la bienséance, c'est alors qu'il apparaît à l'homme comme sa chose" ( $D S$ 1:265). 
Some like us fat, some like us thin, but either way-well, beauty is a trap. And so is the pursuit of beauty, because men are funny about what they want in a woman: "Nature," or the opposite of nature, or some impossible combination. (Pacaly comments, "splendide double-bind!") ${ }^{158}$

Among primitive peoples, the idea men seek simply perfects the common type: a race with thick lips and flat noses creates a thick-lipped, flatnosed Venus; later a more complicated canon of beauty applies. But in any case, the more a woman's form and features seem deliberately crafted, the more she gladdens the heart of man by appearing to avoid the fate of all natural things. A strange paradox ensues: wanting to take hold of nature, but nature transfigured, man dooms woman to artifice. She is not merely physis, but equally antiphysis, and this is true not only in the civilization of electrically permed hair, leg-waxing, and latex girdles, but also where African women wear plates in their lips, and in China, and everywhere on Earth. 159

Something similar happens in a discussion of the social function played by wives:

A man boasts of his wife as he boasts of his house, his lands, his flocks, or his riches, and sometimes more so; through her, he displays his power in the eyes of the world, she is his earthly portion, his worth. In the Orient, the wife must be fat; visibly well-fed, she brings honor to her master. [A footnote refers to the earlier citation from Luquet.] A Muslim gains consequence from the number of wives and their flourishing appearance. In bourgeois society, one role that falls to the wife is to represent: her beauty, her charm, her intelligence, her elegance are the outward signs of her husband's wealth, like the make and model of his car. ${ }^{160}$

$15^{8}$ Pacaly, "La femme et les mythes," 174.

159 "Chez les peuples primitifs, l'idée est seulement celle de la perfection du type populaire: une race aux lèvres épaisses, aux nez plats forge une Vénus aux lèvres épaisses, au nez plat; plus tard on applique aux femmes les canons d'une esthétique plus complexe. Mais en tout cas, plus les traits et les proportions d'une femme paraissent concertés, plus elle réjouit le cœur de l'homme parce qu'elle semble échapper aux avatars des choses naturelles. On aboutit donc à cet étrange paradoxe que, souhaitant saisir dans la femme la nature, mais transfigurée, l'homme voue la femme à l'artifice. Elle n'est pas physis seulement mais tout autant antiphysis; et cela non seulement dans la civilisation des permanentes électriques, de l'épilation à la cire, des guêpières de latex, mais aussi au pays des négresses à plateaux, en Chine et partout sur la terre" ( $D S$ 1:266).

160 "[L'homme] s'enorgueillit de sa femme comme de sa maison, ses terres, ses troupeaux, ses richesses, et parfois même davantage; c'est à travers elle qu'il manifeste aux yeux du 
East or West, zaftig or svelte, a wife is just one more luxury item. Beauvoir closes this discussion with the example of Shakespeare's Taming of the Shrew, where Petruchio calls on all his neighbors to marvel at the docile paragon Katharine has become. ${ }^{161}$

A bit later, cross-cultural examples will again support Beauvoir's explanation that adultery, and men's fear of adultery, is an inevitable result of marriage, and why: marriage involves a mystification, since by claiming to socialize the erotic, it only succeeds in killing it. ${ }^{162}$

Thus [woman] is doomed to infidelity: it is the only face her freedom can wear. She is unfaithful quite aside from her own desires, thoughts, consciousness; regarded as an object, she is offered up to any subjectivity that chooses to seize upon her; shut up in a harem, hidden beneath veils, she may still awaken someone's desire; to awaken a stranger's desire is already to have sinned against one's husband and society. Then too, she is often complicit with this fate; only through deceit and adultery can she disprove men's pretension and show that she belongs to no one. Thus male jealousy is quickly aroused; legends tell us that a woman can be suspected without any reason, then condemned on the barest suspicion, like Geneviève de Brabant and Desdemona; Griselidis is subjected to the harshest of trials even before any suspicion of her can arise; this story would be absurd if woman was not suspect in advance; he does not have to prove her crimes, it is up to her to prove her innocence. That is also why jealousy can be insatiable; we've already shown that possession can never be positively realized; one does not own the spring from which one drinks, even if one forbids others to draw water there, as the jealous man knows very well.... Across all literatures, in the Thousand and One Nights as in the Decameron, women's ruses are seen to triumph over the prudence of men. ${ }^{163}$

monde sa puissance: elle est sa mesure, et sa part sur terre. Chez les Orientaux la femme se doit d'être grasse: on voit qu'elle est largement nourrie et elle fait honneur à son maître. Un musulman est d'autant plus considéré qu'il possède un plus grand nombre de femmes et qu'elles sont d'apparence plus florissante. Dans la société bourgeoise, un des rôles dévolus à la femme, c'est de représenter: sa beauté, son charme, son intelligence, son élégance sont les signes extérieurs de la fortune du mari au même titre que la carrosserie de son automobile" (DS 1:288-89).

161 "[L]e héros de La mégère apprivoisée convoque tous ses voisins pour leur montrer avec quelle autorité il a su dompter sa femme" ( $D S$ 1:289).

162 "[I]l y a dans le mariage une mystification puisque prétendant socialiser l'érotisme, il n'a réussi qu'à le tuer" ( $D S_{1: 305)}$.

163 "La voilà donc vouée à l'infidélité: c'est le seul visage concret que puisse revêtir sa liberté. Elle est infidèle par-delà même ses désirs, ses pensées, sa conscience; du fait qu'on la re- 
The mythic patrimony (so to speak) is here being treated as a kind of grabbag or anthology: neither a set of binary contrasts nor a universal same in which differences are flattened out. Beauvoir's examples may appear to have been chosen almost at random, but they appear side by side rather than in separate boxes, much less in a hierarchical arrangement; the veiled lady whose seclusion fails, here, to truly contain her has precisely the same status as Shakespeare's Desdemona, Bocaccio's Griselda, and the legendary Frenchwoman Geneviève de Brabant. And when Beauvoir says " $\mathrm{t}]$ here is, however, no feminine figure-virgin, mother, wife, sister, servant, lover, fierce virtue, smiling odalisque - capable of encapsulating the inconstant yearnings of man," she is telling us that all these images of Woman are equally imaginary-and none the less powerful and damaging. ${ }^{164}$

Anti-orientalism in The Second Sex: Plus Jamais Claudel

Markowitz professes to find it "curious" that Beauvoir "seems to be all but unaware of her own Orientalism," especially in the light of Beauvoir's strong critique of "the Jewish personality and the black soul."165 In fact, while the ritual gestures of white feminist self-abasement are indeed absent, the myth chapters of The Second Sex do contain some rather biting critiques of European male fantasies of an exotic "other," fantasies Beauvoir links to nationalism and colonialism. (Markowitz may not have seen this because it is advanced by

garde comme un objet, elle est offerte à toute subjectivité qui choisit de s'emparer d'elle; enfermée dans le harem, cachée sous des voiles, on n'est encore pas sûr qu'elle n'inspire à personne du désir: inspirer du désir à un étranger, c'est déjà manquer à son époux et à la société. Mais, en outre, elle se fait souvent complice de cette fatalité; c'est seulement par le mensonge et l'adultère qu'elle peut prouver qu'elle n'est la chose de personne et qu'elle dément les prétentions du mâle. C'est pourquoi la jalousie de l'homme est si prompte à s'éveiller; on voit dans les légendes que la femme peut être soupçonnée sans raison, condamnée sur le moindre soupçon, telles Geneviève de Brabant et Desdémone; avant même tout soupçon, Grisélidis est soumise aux plus dures épreuves; ce conte serait absurde si la femme n'était pas d'avance suspecte; il n'y a pas à démontrer ses fautes: c'est à elle de prouver son innocence. C'est pourquoi aussi la jalousie peut être insatiable; on a dit déjà que la possession ne peut jamais être positivement réalisée; même si on interdit à tout autre d'y puiser, on ne possède pas la source à laquelle on s'abreuve: le jaloux le sait bien.... À travers toutes les littératures, dans Les mille et une nuits comme dans le Décaméron, on voit les ruses de la femme triompher de la prudence de l'homme" (DS 1:307-308).

164 "[I]l n'est aucune figure féminine: vierge, mère, épouse, soeur, servante, amante, farouche vertu, souriante odalisque qui ne soit susceptible de résumer ainsi les ondoyantes aspirations des hommes" ( $D S$ 1:315).

165 Markowitz, "Occidental Dreams," 278. 
means of literary example, and because many of the writers discussed are unfamiliar today outside France.) One strong instance occurs within Beauvoir's discussion of how the figure of Woman comes to serve as an abstraction "assimilated" to cities, regions, nations:166 "This assimilation is not only allegorical; it is realized on the level of feeling [affectivement] by many men." A footnote adds:

It is allegorical in the shameful poem Claudel has recently committed, where he calls Indochina "that yellow woman"; on the other hand, it is emotional [affective] in the verse of the Black poet:

The soul of the black land where the old ones sleep

lives and speaks

tonight

in the trembling strength along your hollow thighs ${ }^{167}$

There is nothing accidental in this juxtaposition, I would submit. My readers may remember Beauvoir's use of Claudel as a target in Pour une morale de l'ambiguité, where he figured as an example of the "serious man": as well as supporting Franco and defending Pétain, Claudel was literally "le Colon," the colonial administrator, whose patriotic pride figured in his attack, in 1925, on the decadence of Surrealism. The "poète noir" to whom Beauvoir contrasts him was Guy Tirolien (1917-88), a close friend and collaborator of Senghor's; the poem she quotes from, "Black Beauty," is addressed to a particular (though unnamed) woman who reminds the speaker of Africa in her face and way of walking (démarche), and in her voice, as well as her body. It is hard not to see this quotation, from a poet of color who was associated with the resistance to

166 She begins by citing Jung on this point, but her examples soon exceed the point he was making.

167 "Cette assimilation n'est pas seulement allégorique: elle est affectivement réalisée par quantité d'hommes. [Note: Elle est allégorique dans le honteux poème que Claudel vient récemment de commettre et où il appelle l'Indochine "C'te femme jaune"; elle est affective au contraire dans les vers du poète noir:

Lâme du noir pays où dorment les anciens

vit et parle

ce soir

en la force inquiète le long de tes reins creux]" (DS 1:292).

I am indebted to Constance Borde and Sheila Malovany-Chevallier for identifying the poet. 
colonialism both in literature and in life, ${ }^{168}$ as a rebuke to Claudel's (literally) imperialist pretensions, which linked a traditionalist nostalgia for "family values" with a vision of the Mission of France Beauvoir found nauseating. ${ }^{169}$

But I wish she had quoted from Claudel's poem, too. It was called "Saint Michel-l'archange, patron desparachutistes du corps expéditionnaire d'Indochine" (Saint Michael the Archangel, Patron Saint of Paratroopers in the Indochina Expeditionary Corps). Dated July 16, 1948, it was written to celebrate France's effort to regain its former colonies after World War II. I found some of it in Claude Roy's autobiography, Moi je, in the course of a discussion of what various writers did during the German occupation of France. Roy refers to Claudel's well-known 1915 ode to Pétain-Tant que vous voudrez, mon général!and to his call for bloody reprisals against Republican Spain, describes him as beating a deaf man's drum to which other collaborators danced in tune, and notes that "He had time, before he died, to consecrate a last ballad to the parachutists of Indochina," from which Roy quotes:

Hail, champion of Ocean!

Hail, policeman of God!

Breton saint! Brutal saint! Colonel, Soldier of a kind,

Help me from above to make her understand, that yellow woman, that this land where we are gaining ground is our land, for which we have paid dear.

168 Born in Guadeloupe, Tirolien studied in France, met Senghor in the Stalag where both were German prisoners, was among the founders of Présence Africaine and held a number of official posts in French African countries, both before and after independence. I wish I knew more about him.

169 In May 1968, observing among the wall slogans "PLUS JAMAIS CLAUDEL” (Never Again Claudel), Leiris would burst out: "In other words: to hell with this elephantine gymnast of the word, bulwark of the bourgeois status quo, sometimes wearing the mask of a very mandarin, very colonial exoticism, and sometimes that of a bookish mystic. (That's how I see things, at least, and I've no reason to think there were different motives behind the rejection so clearly expressed at Nanterre.)" [Autrement dit: foin de ce gymnaste mammouthéen du verbe, ferme appui du statu quo bourgeois, sous le masque tantôt d'un exotisme très mandarin colonial, tantôt d'une mystique de fort-en-thème. (C'est, du moins, comme cela que je vois la chose et je n'ai aucune raison de penser que ce rejet, si catégoriquement exprimé à Nanterre, n'était pas ainsi motivé.)] Other slogans included "Intellectuels apprenez à ne plus l'être" (intellectuals, learn not to be), "la vie vite" (live fast) and "soyez réaliste demandez l'impossible" (be realistic, demand the impossible). Leiris, Frêle Bruit, 167 . 


\section{And I hear the clarion call to the clarion down there which answers across the ricefield... ${ }^{170}$}

(My attempt at literal translation is clumsy, but so is the original poem: it's "honteux," shameful, on more than one level.) I found a bit more of it on the blog of one Michel Volkovitch, under the title "Andouille en parachute":

\section{The Will of God suddenly vertical and severe \\ Which seizes you by the shoulders, plucks you out and throws you back like a stone,}

170 Roy, Moi Je, 221: "Et un autre très grand poète, Paul Claudel, ponctue des roulements d'un tambour de sourd les marches et contremarches des autres. Entre deux vagues du lyrisme le plus ample qu'exhale une poitrine vivante, il va jouer pendant trente ans le Colonel Scrongneugneu de l'intelligentsia. Tant que vous voudrez, mon général! Tant qu'il y en aura un seul! Tant qu'il y en aura un seul de vivant, les vivants et les morts tous à la fois, mâchonnait-il déjà en 1915. En 1937, devant l'Espagne en sang, il récidive: 'Le temps de l'amputation pour l'arbre a fini et c'est le temps des représailles.' Sa pensée politique sera un éternel Tant que vous voudrez! Tant que vous voudrez, mon général Franco! Tant que vous voudrez, monsieur le maréchal Pétain! Tant que vous voudrez, mon général de Gaulle! Il aura le temps, avant de mourir, de consacrer une dernière ballade aux parachutistes d'Indochine:

Salut, champion de l'Océan!

Salut, gendarme de Dieu!

Saint breton! Saint brutal! espèce de colonel et de militaire

Aide-moi lui faire comprendre, elle aussi, c'te femme jaune, par là-dessus

que cette terre où nous prenons pied, c'est la nôtre que nous avons payée cher

Et j'entends le clairon au clairon là-bas qui répond à travers la rizière..."

Tant que vous voudrez, mon général!, the refrain from Claudel's poem of the First World War, is usually translated as, "As many as you wish, my general!" "as many" meaning, as many men, young men for cannon fodder, "until there will only be one left"...); but sometimes it is translated to mean "as far as you wish!" (a simple gesture of blind obedience to authority). In his repetition of the phrase, Roy also alludes to Claudel's bloody-minded and self-righteous early support for Franco, and to his (brief, and later retracted) support for Pétain as leader of the Vichy government. (Roy incidentally displays an unflattering view of General de Gaulle that parallels Beauvoir's view of that General's authoritarian response to the Algerian crisis.) Interestingly, this all comes at the end of a chapter where Roy is attempting to explain why many intellectuals (including himself) moved from right-wing commitments in the 1930 s to become resistance fighters, and later militants for the French communist party; by the time he wrote this, he (and many others) had moved away from Communism as well, in response to the evolution of the Soviet Union, the revelation of the labor camps, and other factors. Claudel, in contrast, never seems to have learned anything. (Roy also mocks him as "le Colonel Scrongneugneu de l'intelligentsia": using a phrase, first attested in an 1884 novel, for "un vieux militaire bougon," a grumpy old military man; "Scrongneugneu" is a blasphemy-avoiding substitute for "sacré nom de Dieu." [See Alice Develey, "Mais d'où vient le mot 'scrongneugneu'?"] No, you didn't need to know that, sorry.) 
So that thundering, unexpected, amid the bulrushes and the unknown, You continue (since I was made for this) the combat of France against the Dragon.

All this to testify to people, one more time, about this Good Thing coming out of the sky

(This Good Thing, with all its weight, to which one's harness is attached)

And may the Dragon be proved wrong once more when he tries to argue with Saint Michael!

Hail, champion of the Ocean! hail, policeman of God!

Representative of everything, in sky, on earth, that tries to understand what it can

Of all the universal which is right against the particular

Of all the spiritual which is right against the secular

Of all that is upright against that which is twisted!

Hail, warrior full of peace and confident of this Father,

Who since there is no other way, tries to make himself understood in bolts of thunder!, etc. ${ }^{171}$

171 "La volonté de Dieu tout à coup verticale et sévère

Qui vous saisit par les épaules, vous arrache et qui vous lâche comme une pierre,

Afin que foudroyant, inopiné, à travers l'inconnu et le jonc,

On continue, puisque je suis fait pour ça, le combat de la France contre le Dragon.

Tout ça est pour attester aux gens une fois de plus cette bonne chose qui vient du ciel

(Cette bonne chose de tout le poids qu'on est à quoi l'on est attaché avec des bretelles),

Et que le Dragon n’a pas raison une fois de plus quand il essaye de discuter avec Saint Michel!

Salut, champion de l'Océan! salut, gendarme de Dieu!

Représentant de tout ce qui là-haut dans le ciel, sur la terre, essaye de se faire comprendre comme il peut,

De tout cela universel qui a raison contre le particulier,

De tout cela spirituel qui a raison contre le séculier,

De tout cela rectiligne qui a raison contre l'entortillé!

Salut, guerrier plein de paix et confident de ce Père,

Puisqu'il n'y a pas moyen autrement, qui essaye de se faire comprendre à coups de tonnerre!" etc.

(Quoted by Volkovitch, "Andouille en parachute.")

Volkovitch fills in the picture and replies with an angry poem of his own, noting that the "clarion call" would be answered by the 1954 defeat of the French at Dien Bien Phu.

St. Michael appears to have been officially claimed as patron saint by French paratroopers as early as World War I; one can buy, on the internet, vintage military medals depicting him, a reminder of the near-total fusion of Church and State Beauvoir describes 
Shameful indeed. One could certainly label this language "orientalizing," but the problem here is of a different order, if I may say. ${ }^{172}$ As Fanon put it in 1952, the Indochinese rose up against the French, not because they had discovered the value of their own culture, but because it was simply becoming impossible for them to breathe. ${ }^{173}$

On a happier note, my search for this piece of garbage (I can't call it a poem) led me to Thi Tuyet Trinh Nguyen's dissertation, L'imaginaire colonial français de l'Indochine 1890-1935, from which I also learned something about one of the few women writers Beauvoir mentions with unmitigated approval in The Second Sex: Andrée Viollis, whose 1935 book, Indochine sos, was a courageous piece of reportage on behalf of the immiserated indigènes and a denunciation of French practices there. ${ }^{174}$ Beauvoir's autobiography mentions reading Viollis's other book, L'Inde contre les Anglais, when it appeared in 1930. ${ }^{175}$ India against the English. 1930. Hmm.

in Mémoires d'une jeune fille rangée. This is the France for which Claudel, and Beauvoir's bourgeois readers, were nostalgic.

Wikipedia, however, informs me that those who carried out France's colonial war "included colonial troops from the whole former empire (Moroccan, Algerian, Tunisian, Laotian, Cambodian, and Vietnamese ethnic minorities), French professional troops and units of the French Foreign Legion. The use of metropolitan recruits was forbidden by the government to prevent the war from becoming even more unpopular at home. It was called the 'dirty war' (la sale guerre) by leftists in France."

172 One can see why W.H. Auden mentions Claudel in the same breath as Kipling in the quatrain from his Yeats elegy that constitutes the only time many Anglophones are likely to have heard his name: Claudel is the French version of the "white man's burden." One does not, however, see why Auden thought that Time would pardon Paul Claudel "for writing well." However, I did find some surprising literary-critical éloges of Claudel's later poems, which reflect his "love" of the East by translating from languages he never seems to have learned (despite his long sojourn as a diplomat in China and Japan). "And yet, this apparent lack of knowledge might also be considered an advantage (as Roland Barthes later stated about his own inability to speak Japanese); the poet came to learn of these cultures through his own direct experiences" (Pamela Genova, "Knowledge of the East? Paul Claudel and the Equivocal Nature of Cultural Exchange," 105). Despite the title, there is no mention here of such post-Saidian sins as "cultural appropriation." Sometimes scholarship seems to take place in sealed compartments.

173 “Ce n'est pas parce que l'Indochinois a découvert une culture propre qu'il s'est révolté. C'est parce que, 'tout simplement' il lui devenait, à plus d'un titre, impossible de respirer" (PNMB 183, BSWM 176).

174 See Thi Tuyet Trinh Nguyen, L'imaginaire colonial français de l'Indochine 1890-1935. Beauvoir says, simply, that "no male journalist has outdone Andrée Viollis's accounts of Indochina and India" [aucun journaliste masculin n'a surclassé les témoignages d'Andrée Viollis sur l'Indochine et sur les Indes $(D S$ 2:635)].

$175 \quad F A 58$ 
Perhaps Beauvoir's invocation of these telling names feel like asides, and perhaps they are. But insofar as Beauvoir's anti-imperialist commitments merely "haunt the margins" here (in contrast to the way they are foregrounded in Pour une morale de l'ambiguïté, L'Amérique au jour le jour 1947, and especially La force des choses), it seems to me this was in part because she expected her readers to easily follow such sideways references as "the shameful poem Claudel recently committed." (Fellow intellectual Claude Roy, for instance, seems to have quoted it from memory in a book he wrote twenty years later.) It is unlikely that readers outside France would have picked up on these particular references, even at the time; but I think Beauvoir's political point resonates through the paragraph that follows her discussion of Tirolien and Claudel. She is listing various instances where women figure as stand-ins for what is different or Other about a land across a border.

It often happens that the traveler asks woman to provide the key to lands he visits: holding in his arms an Italian or Spanish woman, he thinks he possesses the delicious essence of Italy or Spain. "When I arrive in a new city, I always go first to the brothel," a journalist has said. If a cup of hot chocolate spiced with cinnamon can reveal all of Spain to Gide, how much more strongly the kisses from an exotic mouth render up to the lover a country's flora and fauna, its traditions, its culture. Woman does not sum up its political institutions nor its economics; but she embodies at the same time the marrow of its flesh and its mystical mana. From Lamartine's Graziella to the novels of Loti and the stories of Morand, it is through women that we see the foreigner trying to appropriate for himself the soul of a region. Mignon, Sylvie, Mireille, Columba, Carmen unveil the most intimate truth of Italy, the Valais region, Provence, Corsica, Andalusia. When Goethe made the Alsatian Frédérique his lover, it seemed to the Germans a symbol of the annexation of Germany; reciprocally, when Colette Baudoche refused to marry a German, that was for Barrès Alsace refusing itself to Germany. ${ }^{176}$

${ }_{176}$ "Il est fréquent que le voyageur demande à la femme la clef des contrées qu'il visite: quand il tient une Italienne, une Espagnole dans ses bras, il lui semble posséder l'essence savoureuse d'Italie, de l'Espagne. 'Quand j'arrive dans une nouvelle ville, je commence toujours par aller au bordel,' disait un journaliste. Si un chocolat à la cannelle peut découvrir à Gide toute l'Espagne, à plus forte raison les baisers d'une bouche exotique livreront à l'amant un pays avec sa flore, sa faune, ses traditions, sa culture. La femme n'en résume pas les institutions politiques ni les richesses économiques; mais elle en incarne à la fois la pulpe charnelle et le mana mystique. De Graziella de Lamartine aux romans de Loti et aux nouvelles de Morand, c'est à travers les femmes qu'on voit l'étranger tenter 
Here is some of the same generalized touristic exoticism/eroticism that we saw in L'invitée. But the cure "in the real" that I described at the end of that book seems to have happened more fully by the time of The Second Sex. Or at least, this is a more overt diagnosis. Remember (again) that the discussion is embedded in a lengthy recital of male fantasies and why they matter. The German/French examples, at least, show clearly her awareness of the wider political stakes of what Lévi-Strauss called the "exchange of women," and not just among the Yanomami or the Sabines but de nos jours. At the infamous 1925 banquet, when Soupault swung from the chandelier and Leiris was arrested for shouting "Vive l'Allemagne!" the Surrealists were protesting exactly this sickly blend of patriotism expressed across women's bodies, attacking the symbolist writer Rachilde for the same sentiments expressed in Maurice Barrès's novel Colette Baudoche. Like the Surrealists, Beauvoir connected this to anticolonialist critique. It is not a coincidence that several of the writers she mentions here-Loti, Morand, Barrès - were right-wing writers, deplorers of "decadence," apologists for empire, and racists of the non-subtle sort. Morand, for instance, directly collaborated with and served the Vichy government, and while Barrès did not live long enough to do so, he certainly prepared the ground with novels such as Les déracinés. ${ }^{177}$ Loti, Claudel, Morand all served in colonial armies and/or as bureaucrats (you will recall the pride Claudel took in this when rebuking the Surrealists).

I said earlier, near the discussion of L'invitée, that it was not a simple matter to disentangle Beauvoir's relationship to some of the orientalizing and eroticizing discourses about race that she found in her social and intellectual circle, and that is true also here. But I want to ask which orientalism we are really dealing with. Just saying "orientalism" as an ahistorical moniker is not especially helpful if (and I guess that's a big if) we're trying to actually understand the thing. National traditions differ. The eighteenth century and the twentieth century differ. And, as Emily Apter explains in an important article, even then there's a lot to know.

An immediate problem in addressing these concerns lies in the fact that French colonial literature is made up of a nasty tissue of Orientalist

de s'approprier l'âme d'une région. Mignon, Sylvie, Mireille, Columba, Carmen dévoilent la plus intime vérité de l'Italie, du Valais, de la Provence, de la Corse, de l'Andalousie. Que Goethe se soit fait aimer de l'Alsacienne Frédérique est apparu aux Allemands comme un symbole de l'annexion de l'Allemagne; réciproquement, quand Colette Baudoche refuse d'épouser un Allemand, c'est aux yeux de Barrès l'Alsace qui se refuse à l'Allemagne" (DS 1:292).

177 See Renee Winegarten, “Who Was Paul Morand?" 
clichés; romantic physiognomical and characterological typologies, racist sexual fantasies, and frozen, "postcarded" images of native subjects indiscriminately shuffled between black, brown, métis, Asiatic, Arab, Kabylian, Moorish, Ottoman, Bedouin, Islamic, and Byzantine cultural frames. The reader risks reinforcing these stereotypes even in endeavouring to undo them. Equally complicated is the historiographical task of constituting a textual canon. A motley assortment of authors falls under this rubric, including Parisian literati interested in updating realist exoticism, modernist Orientalists seduced by the spectacular stage-setting of the East, North African writers writing in French, amateur ethnographers with a taste for the tourist sublime, colonial civil servants proselytizing for la mission civilisatrice, cross-dressing journalists, female voyeurs, and ex-harem wives. ${ }^{178}$

Markowitz speculates that Beauvoir's "orientalism" might have come to her from Hegel via Marx; she also refers to the work of Alain Grosrichard, a psychoanalytic reading of "the Western imagination" starting from the eighteenth century and Montesquieu. But Beauvoir knew Hegel directly, and we can tell that the orientalism with which The Second Sex overtly engages comes not from philosophy but from storybooks.

Beauvoir's association of "the East" with a different, and a forbidden, sexuality does in fact run very deep: she tells us so herself in Mémoires d'une jeune fille rangée. At a very young age (the First World War had not yet ended), she describes the masochism that her pious upbringing inspired; ${ }^{179}$ in the absence of any precise information about sexuality, she identified in fantasy with Mary Magdalene wiping the feet of Christ with her long hair, with saints and martyrs (including Geneviève de Brabant) who suffered nobly at the hands of men, and with Bluebeard's wives.

Certain of my fantasies would not bear the light of day; I had to indulge them in secret. I was always extraordinarily moved by the fate of that captive king whom an Oriental tyrant used as a mounting-block; from time to time, trembling, half-naked, I would substitute myself for the royal slave and feel the tyrant's sharp spurs riding down my spine. ${ }^{180}$

178 Emily Apter, "Female Trouble in the Colonial Harem," 207-8.

179 "Ma piété me disposait au masochisme" (Mémoires d’une jeune fille rangée, hereinafter $M J F R, 80)$.

180 "Certains de mes phantasmes ne supportaient pas la lumière; je ne les évoquais qu'en secret. Je fus extraordinairement émue par le sort de ce roi captif qu'un tyran oriental 
I haven't identified exactly what Beauvoir was reading, but her account seems like a fitting synecdoche for the process by which Christian Europe, ashamed of and yet fascinated by sexual desire, denied the importance of the body (to the extent of refusing to educate children about it), connected eroticism to the mortification of the flesh, and then simply outsourced the whole subject to "the East." Throughout her adolescence, Beauvoir had a significant encounter with a rather steamy (and seamy) turn of the century literature that was indeed connected with Empire, in that it was written by many of the same people responsible for carrying out the Empire's actual work. Gide, Loti, Morand, and Barrès all exoticized and eroticized the mysterious East, and they were all writers the young Beauvoir had liked and valued (as for that matter was Claudel, one of her best friend Zaza's particular favorites). We've seen already what an important influence Gide was: in fact, when she and Sartre first crossed the Spanish border, almost the first thing they did, following his instructions, was to order a cup of bitter hot chocolate and religiously inhale it in order to "drink in all of Spain."181 By the time she wrote the memoir, she was telling this as a funny story, amused at the credulity of her younger self; but the fact is that, in their later travels through the Maghreb, they were explicitly following Gide's traces and his instructions that there was something important to see there, something that could not be found in France. ${ }^{182}$ Even on the solo trip where she saw the women living in the cave, she notes signs that Gide had been there before her (his signature in a hotel register in Nefta, and carved into a public bench in El Oued). ${ }^{183}$ However, she also recounts her discomfort on a train whose conductor, after cursing and cuffing the Arab passengers, tells her that because she is a European she does not have to pay.

utilisait comme marchepied quand il montait à cheval; il m'arrivait de me substituer tremblante, demi-nue, à l'esclave dont un dur éperon écorchait l'échine" (MJFR 81).

181 FA 97-8.

182 And there was, though it may not have been what Gide meant them to see. The case of Gide is more complicated than that of his old arch-adversary Claudel, and of the other writers discussed here; I can't really go into it fully now. Gide's profound and perfectly oldfashioned, erotically-inflected orientalism may keep us from fully enjoying L'immoraliste: sexual freedom, bien ok, but for whom? (What freedom exists for the boy? For the woman in the harem — and here I mean Gide's own harem.) However, his orientalism didn't keep him from speaking out against the abuses he saw on his trip to the Congo, and throwing his considerable cultural weight behind this; and his leftist sympathies didn't prevent him from saying what he saw in Retour de l'URSS. Perhaps his embrace of Whitman's sublime insouciance about contradicting oneself was productive? Lives are more complex than labels.

183 FCh 1:87-8, FCirc 66-67. 
Given this context, the paragraph I quoted above about women and cities has the flavor of an exorcism. When you're young, you read what's put in front of you, you read what the people around you are reading, you look for what you need in all the wrong places. But then you grow up. Beauvoir's mature work mentions these orientalist writers, I think, largely for the same reason the story of the captive king figures in Mémoires d'une jeune fille rangée: because she outgrew them.

An even more obscure example of this "self-cleansing" in The Second Sex relates to Jean-Richard Bloch's 1925 novel, La nuit kurde. After describing the inextricable mixture of love and hate that characterizes men's sexual myth of Woman (lover and mother, representative of their own fleshly contingence and thus their own finitude), Beauvoir says, introducing a very long quotation: "A revealing text where we will find a synthesis of almost all these myths is the scene where Jean-Richard Bloch in La nuit kurde describes young Saad's sexual encounter with a woman older than himself, but still beautiful, in the course of the sack of a city."184 Now, in her memoirs, Beauvoir describes her mother discovering La nuit kurde among her adolescent reading, leafing through it, and turning pale. ${ }^{185}$ And Mme. de Beauvoir was right, for once: the book is vile. It is a lyrical but lurid fantasy involving a variety of racial mythologies: a halfKurdish, half-Christian hero, somewhere in Asia Minor (?), carries out rape, pillage, and cannibalism against the Greek Christian village where his beloved lives. The narrative is prefaced by a declaration of extreme French nationalism on the part of the author, and concludes with a breathless "farewell to Asia," making the geographical "outsourcing" of sexual fantasy absolutely explicit. It is easy enough to see what made Maman feel faint, and also easy to see why this would, during Beauvoir's period of imaginative revolt against the stifling atmosphere of her home and the Cours Desir, have seemed like a point in its favor. ${ }^{186}$

184 "Un texte significatif où nous allons trouver une synthèse de presque tous ces mythes, c'est celui où Jean-Richard Bloch dans La nuit kurde décrit les étreintes du jeune Saad avec une femme plus âgée que lui, mais encore belle, au cours du sac d'une ville" (DS 1:274).

185 MJFR 313.

186 "I was in exactly the same position as these disoriented young men from good families; I wanted to separate myself from the class I belonged to, but where, then, was there to go? ... I vowed allegiance to the cult of Disquiet [l'Inquiétude].... I was just as quick to embrace Immoralism. Of course, I did not approve of people stealing out of self-interest or jumping into bed just for pleasure; but I was unflinchingly prepared to accept all kinds of vices, rapes, assassinations, as long as they were gratuitous acts, acts of desperation and revolt—and, needless to say, imaginary. Doing evil, that was the most radical way to repudiate any complicity with respectable people." [J'étais exactement dans la même situation que ces fils de famille désaxés; je me séparais de la classe à laquelle j’appartenais: 
It is harder to understand why the grown-up Beauvoir would have found this bizarre fantasy of enduring interest, even as a source of "myths," powerful (wrong) visions of women. From the very few critics who have taken an interest in Bloch, I have learned that his early work deals with questions of antiSemitism and Jewish assimilation in bourgeois France, and that he became a passionate Zionist, and later a communist writer, praised by Aragon. ${ }^{187}$ None of which sheds much light on La nuit kurde, and in particular on what I must simply call racism of a disturbingly sexualized sort. ${ }^{188}$ The book is the fantasy product of an identity crisis on the part of its author, who had seen no more of the Arab world than Boris Vian saw of America, but who nonetheless (over and over and over) attributes what someone says or does, down to the most minute physical detail or trembling nuance of feeling, directly (and explicitly) to that person's racial heritage.

However, apart from the book's title, there's nothing in Beauvoir's quotation that situates what it describes anywhere on Earth - and the entwined, vibrating bodies involved are not racialized in any way. What we see is pretty simply a sex-murder, and Beauvoir quotes not with tweezers but with scissors, a habit of hers with which we are by now familiar. I think we are simply meant to be fascinated and appalled by the extent to which lust and woman-hating can fuse into a single impulse.

Parshley seems to have had the same response to La nuit kurde as Beauvoir's mother did: he simply left the whole thing out, and for once it's hard to blame him. In fact, I must confess that Bloch's book is so repellent that I have been unable to read it through from cover to cover. Every page drips with sexual

où aller? ... Je me vouai à l'Inquiétude.... Je ne mis pas moins d'empressement à embrasser l'immoralisme. Certes, je n'approuvai pas qu'on volât par intérêt ni qu'on s'ébattît dans un lit pour le plaisir; mais s'ils étaient gratuits, désespérés, révoltés-et bien entendu imaginaires-j'encaissais sans broncher tous les vices, les viols et les assassinats. Faire le mal, c'était la manière la plus radicale de répudier toute complicité avec les gens de bien (MJFR 270).]

187 See Jean Albertini, "Jean-Richard Bloch, de l'affaire [Dreyfus] à La nuit kurde," and Michel Trebitsch, "De la situation faite à l'écrivain juif dans le monde moderne': Jean-Richard Bloch, entre identité littérature et engagement." These scholars have convinced me that Bloch was, in fact, a complex and interesting writer, and a sincerely engaged man of the left (much as might be argued for Boris Vian). But neither scholar has much good to say for La nuit kurde, which the always cogent and insightful Trebitsch compares to an "OVNI," a UFO. At best it can be situated, and explained, as a partial allegory for the uniquely torturous position occupied at that period by "assimilated" Jewish writers in a virulently anti-Semitic culture. An explanation, but not an excuse.

188 He also published a récit de voyage called Première journée à Rufisque, which apparently takes up homosexual questions described by Paul Renard as "épineuses et choquantes," thorny and disturbing (Paul Renard, "Jean-Richard Bloch," 47). 
feeling, and scenes proceed at a glacial pace in order to emphasize this. It is very much a young man's book. ${ }^{189}$ In this case, the young man happens to be a kind of "tragic mulatto," since his mother was a Christian, and (stereotype piled on stereotype) racial currents are fighting themselves out within the hero, as well as between the nomadic group to which he (uneasily) belongs and the Nestorian Christians in the town where his beloved lives. ${ }^{190}$ I cannot really give an account of "what the book is trying to say." Like Vian's, it was cobbled together from other books, rather than informed by actual knowledge. ${ }^{191}$ As such, it reveals a great deal about what fantasies were received as "authentic" at a certain time-or at least authentic enough to sell. But I do not think it tells us anything much about Beauvoir, who simply seems to have unzipped it from the cultural context and used it to illustrate something else: the close approach, in the structure of male fantasy, between sex and death. The reason it is quoted at such length is-excuse my French - to show how fucked up this is. And if the response is, "but, Madame, this is typique," her response would be: "right, my point exactly."

But one is always more influenced than one thinks. On the very next page she returns to cultural comparison, with the same confusing mixture of synchrony and diachrony we saw in the history section, some of the same points, and some of the same problems.

Many different attitudes are available for the man, as he may emphasize one aspect or another of the carnal drama. If a man does not have the idea that his life is unique, if he is not concerned with his singular destiny, he does not fear death and accepts his animal nature with joy. Among Muslims, woman is reduced to a lowly condition because the feudal structure of society permits no recourse to the State against the family, on account of religion which, expressing the warrior ideal of this civilization, has dedicated man directly to death and deprives woman of her magic: what need he fear, who is ready to plunge from one moment to the next into the voluptuous orgies of the Mohammedan paradise? The man can thus calmly enjoy woman with no need of defense, either against

189 Young Saad has an awful lot in common with such French juvenile heroes as Marcel Arland's Étienne or even Benjamin Constant's Adolphe: the case could be made that this is, in fact, a book about France, and that Beauvoir was right to disregard the setting.

190 Those who wish to claim Bloch as an important and neglected twentieth-century writer tend to understand this as a tortured reflection on the situation of the Jewish writer in France.

191 Albertini ("Jean-Richard Bloch, de l'affaire à La nuit kurde," 251) says it was built around a fait divers ("human interest story") Bloch read by chance in the newspapers in 1920. 
himself or against her. The stories of the Thousand and One Nights regard her as a source of creamy delight in the same way as fruits, preserves, opulent cakes, perfumed oils. Today the same kindly sensuality can be found among many Mediterranean peoples... ${ }^{192}$

The examples which follow are from a modern Italian novel, but I think it is possible that what makes least sense in this paragraph bleeds over from the confused imaginary of La nuit kurde. However, this is merely the opening salvo in a paragraph that runs for no fewer than five solid pages without drawing breath. I simply cannot quote it, but after this brief introduction to Oriental "bienveillance" toward women, the "on the other hand" part-everything that is vile about the Christian view of women (quotes from Tertullian, etc.) - takes up fully four of those pages. The point is the paradox. Eastern and Southern peoples subjugate women socially and politically, but treat them with appreciation as sexual partners; Christianity pretends to elevate woman to the status of a human being, but this is a dirty trick: she is still reduced to a debased and hateful Other by her association with the corruptions of the flesh. This is equally true of all that follows in Christianity's wake, for instance, psychoanalysis.

Facing [the woman], man feels the strongest conviction of his own fleshly passivity. Woman is a vampire, a slut, an eater and drinker of men; her sex organ feeds gluttonously upon his. Certain psychoanalysts have tried to give a scientific basis to these fantasies: supposedly all the pleasure woman derives from intercourse would come from symbolically castrating the male and appropriating his penis. But it seems that these theories themselves call out to be psychoanalyzed, and that the doctors who invented them have projected their own ancestral terrors. ${ }^{193}$

192 "Beaucoup d'attitudes sont ici possibles à l'homme, selon qu'il met l'accent sur tel ou tel aspect du drame charnel. Si un homme n'a pas l'idée que la vie est unique, s'il n'a pas le souci de sa destinée singulière, s'il ne redoute pas la mort, il acceptera joyeusement son animalité. Chez les musulmans, la femme est réduite à un état d'abjection à cause de la structure féodale de la société qui ne permet pas le recours à l'État contre la famille, à cause de la religion qui, exprimant l'idéal guerrier de cette civilisation, a voué directement l'homme à la Mort et a dépouillé la femme de sa magie: que craindrait sur terre celui qui est prêt à se plonger d'une seconde à l'autre dans les voluptueuses orgies du paradis mahométan? L'homme peut donc tranquillement jouir de la femme sans avoir à se défendre contre soi-même, ni contre elle. Les contes des Mille et une nuits la regardent comme une source d'onctueuses délices aux même titre que les fruits, les confitures, les gâteaux opulents, les huiles parfumées. On retrouve aujourd'hui cette bienveillance sensuelle chez beaucoup de peuples méditerranéens" ( $D S$ 1:276).

193 “C'est en face d'elle que l'homme éprouve avec le plus d'évidence la passivité de sa propre chair. La femme est vampire, gouge, mangeuse, buveuse; son sexe se nourritgloutonnement 
Yes, evidently. You know, it's really tough for me to see this as a progress narrative. There hasn't been any progress.

\section{$7 \quad$ Pour en finir avec Montherlant}

The "Oriental" sexual appreciation of women makes a final appearance in Beauvoir's discussion of Henri de Montherlant, a deservedly forgotten Fascist writer, ${ }^{194}$ whose attitude toward women was as violent and domineering as his racism was glaring. Montherlant gets his own chapter in the part of the myth section given over to "myths of women in five authors." As I said in my discussion of Surrealism, these chapters often feel skippable, but they are important because they show that "myths" are still with us in the modern age, and because by close-reading male writers who are usually viewed as representing divergent, even opposite, literary "schools," and nonethless drawing remarkably similar conclusions, Beauvoir creates an implicit category of, well, masculinist writing. Entering the arena of combat about what literature should be, and do, she attacks her living compatriots, and condemns them out of their own mouths. As Susan Suleiman showed for the chapter on André Breton, Beauvoir's method is "death by citation" - actually taking seriously what men say their ideas about women are, actually listening to them, could be enough to bring on a rousing cry of "goodbye to all that." (In the words of a recent meme: "When someone tells you who they are, believe them.") Margaret Zimmerman sees this chapter in particular as a "mise à mort" or execution which harks back to Christine de Pizan and the querelle des femmes and looks forward to the feminist critiques of the $1970 \mathrm{os} .{ }^{195}$ Montherlant's vision of women as monstrous destroyers of all that is virile and valuable is exposed and mocked as a selfaggrandizing fantasy: the emperor has no clothes, and his despisal of the feminine is revealed as a fear of confronting his equals, a fear of the real.

In this chapter it becomes even clearer that when Beauvoir speaks of "the Oriental attitude" toward women, she is speaking of a Western fantasy. The "Oriental male" here is not simply a foil for any Westerner, he is specifically a

du sexe mâle. Certains psychanalystes ont voulu donner des bases scientifiques à ces imaginations: tout le plaisir que la femme tire du coït viendrait de ce qu'elle châtre symboliquement le mâle et s'approprie son sexe. Mais il semble que ces théories elles-mêmes demandent à être psychanalysées et que les médecins qui les inventèrent y aient projeté des terreurs ancestrales" ( $D S$ 1:279-80).

194 For some good background on French fascism in the realm of letters, see Richard Golsan, French Writers and the Politics of Complicity: Crises of Democracy in the 1940s and 1990 os.

195 Margarete Zimmerman, "Le mythe de la femme et les écrivains: Montherlant ou le pain du dégoût," in Galster, Simone de Beauvoir, 192. 
foil to Montherlant, who believes (wrongly) that he has inserted himself into the tradition of the Thousand and One Nights.

Women's appropriate role, according to Montherlant, is to be purely flesh. He approves of the Oriental attitude: as an object of pleasure, the weaker sex has a place on Earth, a humble place it is true, and yet a worthwhile one, justified by the pleasure the male derives from her and by that pleasure alone. The ideal woman is perfectly stupid and perfectly submissive; she is always ready to receive the man, asking nothing in return. Such a one is Douce, who Alban [the hero of Montherlant's Le songe], appreciates when it suits him, "Douce, admirably foolish and more desirable the more foolish she is; when not making love she is useless, and then he gently but firmly avoids her." Such a one also is the little Arab Radidja, a peaceful love-beast who docilely accepts pleasure, and money. Such, we imagine, was that "female animal" he came across on a Spanish railway train: "She seemed so brutish [abruti] that I began to desire her." The author explains, "what is so annoying about women is their claim to reason; when they concentrate on their animality, they begin to be superhuman."196

But Montherlant's disgust for women's bodies, and for the fear of his own flesh he experiences in their presence, reveal a more modern (and more Christian) attitude.

However, Montherlant is not in the least an Oriental Sultan: to start with, he has no sensuality. He is far from delighting without a backward glance in "female animals": they are "sick, diseased, never entirely clean." The Oriental partakes voluptuously of woman and thus a carnal reciprocity is established between lovers: that is what we see in the ardent invocations

196 "Ce qui convient à la femme, c'est d'être purement chair. Montherlant approuve l'attitude orientale: en tant qu'objet de jouissance, le sexe faible a sur terre une place, humble sans doute, mais valable; il trouve une justification dans le plaisir qu'en tire le mâle et dans ce plaisir seul. La femme idéale est parfaitement stupide et parfaitement soumise; elle est toujours prête à accueillir l'homme, et ne lui demande jamais rien. Telle est Douce, qu'Alban apprécie à ses heures, 'Douce, admirablement sotte et toujours plus convoitée à mesure que plus sotte ... inutile en dehors de l'amour et qu'il évite alors avec une douceur ferme.' Telle est la petite Arabe Radidja, tranquille bête d'amour qui accepte docilement plaisir et argent. Telle peut-on imaginer cette 'bête féminine' rencontrée dans un train espagnol: 'Elle avait l'air si abruti que je me suis mis à la désirer.' L'auteur explique: 'Ce qui est agaçant chez les femmes, c'est leur prétention à la raison; qu'elles exagèrent leur animalité, elles ébauchent le surhumain"' ( $D S$ 1: $\left.325^{-26}\right)$. 
of the Song of Songs, the tales of the Thousand and One Nights, and so many Arab poems to the glory of the beloved; some women are bad, of course; but others are delightful, and in their arms the sensual man abandons himself confidently, feeling no humiliation. Montherlant's hero, on the contrary, is always on the defensive: "To take without being taken, that is the only acceptable motto for the superior man's relation to woman."197

I cannot recognize, here, Markowitz's "generalized Oriental male, who cannot or will not rouse himself from his lethargic sensuality," and certainly Montherlant's modern misreading of the Thousand and One Nights is no improvement on the original: Beauvoir is arguing just the opposite.

The discussion also fails to confirm Markowitz's claim that "Beauvoir, a trenchant critic of the notions of the 'Jewish personality' and the 'black soul,' has nothing more to say about" this "Oriental male," nor do I see any purchase for the rather condescending concession with which she follows up: "After all, mainstream Western feminist discourse, even when questioning itself about race, has until recently lacked the sort of theoretical framework that could bring these remarks into sharp relief and suggest how to understand them."198

In fact, Beauvoir did have such a framework, as we saw in her discussion of the bad faith of le colon in Pour une morale de l'ambiguité; its main points are reprised here. In the last chapter of the myth section, which pulls together her previous arguments, she investigates the myth of woman's supposed "Mystery." She describes this as providing men with "an alibi which flatters both their laziness and their vanity,"199 and as entirely oppressive to those who are seen as "mysterious" rather than as fully human. True, their status of dominated Other can lead women to play along with the game:

197 “Cependant Montherlant n'est en rien un Sultan oriental: il lui manque d'abord la sensualité. Il est loin de se délecter sans arrière-pensée des 'bêtes féminines'; elles sont 'malades, malsaines, jamais tout à fait nettes.' ... L'Oriental goûte voluptueusement la femme et par là s'établit entre amants une réciprocité charnelle; c'est ce que manifestent les ardentes invocations du Cantique des cantiques, les contes des Mille et Une Nuits, et tant de poésies arabes à la gloire de la bien-aimée; certes, il y a de mauvaises femmes; mais il en est aussi de savoureuses, et l'homme sensuel s'abandonne à leurs bras avec confiance, sans s'en trouver humilié. Tandis que le héros de Montherlant est toujours sur la défensive: 'Prendre sans être pris, seule formule acceptable entre l'homme supérieur et la femme'" (DS 1:326).

198 Markowitz, "Occidental Dreams," 273.

199 “[U]n alibi qui flatte à la fois la paresse et la vanité" ( $D S$ 1:399). 
Sometimes, like all oppressed people, she deliberately conceals her real face: the slave, the servant, the indigène, all those who depend on the caprices of a master have learned to meet him with a changeless smile or an enigmatic impassivity, carefully hiding their real feelings and their real activities. Woman too is taught from adolescence to lie to men, to be cunning, to sidestep the issue. ${ }^{200}$

But the question is deeper. "Quite apart from any secrecy that comes from dissimulation, there is a mystery of the Black, the Yellow [Jaune], insofar as they are considered absolutely as the inessential Other."201

I suppose Markowitz can be forgiven for not noticing the word "Jaune" amid so many densely argued pages. But the idea that Beauvoir "lacked" the right "sort of theoretical framework" to understand her own remarks...? It might be better simply to accept that, as Toril Moi has shown for other matters, Beauvoir's questions were not ours. Her framework was not missing, but different. What was it? Beauvoir notes that not all cultural differences are seen as mysterious:

Note that the American citizen, whom the average European finds deeply disconcerting, is nonetheless not considered "mysterious"; we say, more modestly, that we just don't understand him. Thus, while women don't always "understand" men, there is no "masculine mystery." Rich America, and the male, are on the side of the Master, and Mystery is a property of the slave. ${ }^{202}$

It is a question of relative social power-as she says a bit earlier, there is "an infrastructure of feminine mystery which is of an economic order"203 - and she provides a class analysis which cuts across cultural boundaries:

200 "[I]l arrive que, comme tous les opprimés, elle dissimule délibérément sa figure objective; l'esclave, le serviteur, l'indigène, tous ceux qui dépendent des caprices d'un maître ont appris à lui opposer un immuable sourire ou une énigmatique impassibilité; leurs vrais sentiments, leurs vraies conduites ils les cachent soigneusement. À la femme aussi on apprend depuis l'adolescence à mentir aux hommes, à ruser, à biaiser" ( $D S$ 1:402).

201 "[I]l y a, par-delà le secret que crée leur dissimulation, un mystère du Noir, du Jaune, en tant qu'ils sont considérés absolument comme l'Autre inessentiel" ( $D S$ 1:403).

202 "Il faut remarquer que le citoyen américain qui déconcerte profondément l'Européen moyen n'est cependant pas considéré comme 'mystérieux': plus modestement on assure qu'on ne le comprend pas; ainsi la femme ne 'comprend' pas toujours l'homme, mais il n'y a pas de mystère masculin; c'est que la riche Amérique, le mâle, sont du côté du Maître et

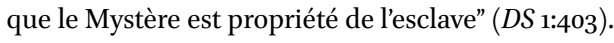

203 "[U]ne infrastructure du mystère féminin qui est d'ordre économique" ( $D S$ 1:401). 
Thus we see that myth is mostly explained by the use men make of it. The myth of woman is a luxury. It can only appear if man escapes the urgent grip of his needs; when relationships are more concretely lived, they are less idealized. The fellah of ancient Egypt, the rural Bedouin, the medieval artisan, the workingman today has, through the rigors of work and poverty, too specific a relationship with the particular woman who is his companion to gild her with magical powers to help or harm. It is the eras, and the classes, which have sufficient leisure to dream that have built the dark and the gleaming statues of femininity. But luxury too has its uses; these dreams are imperiously driven by vested interests. ${ }^{204}$

This sort of analysis should by now feel familiar.

Where Beauvoir's hatchet job on Montherlant was tending was towards her general theory of domination, which applied to the question of men and women but did not stop there (and as we have seen did not originate there). Montherlant's heroes first render women abject and then despise them; this is also the attitude of the author himself, not just toward women but toward the "weak" generally, as can be seen in his denunciations of the vanquished French, his collaboration with Vichy, his worship of Force, and his contempt for those who have been defeated simply because they have lost. As she says, he sums up this attitude himself, in Solstice de juin, where he describes pissing on a nest of caterpillars, choosing with a lordly power to save some from the fire-those who show some "fight" — and to let the rest perish. (As with the Claudel poem I discussed above, Beauvoir expects her readers to be familiar with this infamous passage and does not quote or really explain it.) The scene, she says, expresses the same capricious domination Montherlant's heroes show for women, having first reduced them to the status of animals; it is the same contempt the whites of Georgia and Alabama show to the Blacks, the same "avilissement" and dehumanization the Nazis practiced in concentration camps. And "there is nothing accidental," she says, about this parallel: "Montherlant's admiration

204 "Ainsi nous voyons que le mythe s'explique en grande partie par l'usage que l'homme en fait. Le mythe de la femme est un luxe. Il ne peut apparaitre que si l'homme échappe à l'urgente emprise de ses besoins; plus des rapports sont concrètement vécus, moins ils sont idéalisés. Le fellah de l'ancienne Égypte, le paysan bédouin, l'artisan du Moyen Age, l'ouvrier contemporain ont dans les nécessités du travail et de la pauvreté des rapports trop définis avec la femme singulière qui est leur compagne pour la parer d'une aura faste ou néfaste. Ce sont les époques et les classes à qui étaient accordés les loisirs de rêver qui ont dressé les statues noires et blanches de la féminité. Mais le luxe a aussi une utilité; ces rêves étaient impérieusement dirigés par des intérêts" ( $D S$ 1:404). 
for the Nazis is well known."205 The rest of the chapter goes on to document this, to call out his hypocrisy and mock him for seeing his own abasement before the victors as implying that he partakes of their superior force, rather than revealing his own cowardice.

Margaret Zimmerman notes that Beauvoir moves from Montherlant's attitude toward insects and women to the Southern racists and the Nazis with a simple "ainsi" (thus) — "an argument that today seems a little 'facile." 206 But it would not have seemed facile to readers for whom French collaboration with the occupiers was still a gaping wound, who remembered that the journal Je suis partout - to which Montherlant contributed—had called for the murder of Jews, and pointed out their hiding-places. ${ }^{207}$

But We Know So Much More about This Now

What Markowitz means by the "theoretical framework" which Beauvoir lacked but which we, luckily, have, is perhaps exemplified by Emily Apter's well-known

205 'La clé de cette attitude, c'est l'apologue des chenilles qui nous la fournit: quelle qu'en ait été l'intention cachée, il est par soi-même assez significatif. Compissant des chenilles, Montherlant s'amuse à en épargner certaines, à en exterminer d'autres; il accorde une pitié rieuse à celles qui s'acharnent à vivre et les laisse généreusement courir leur chance; ce jeu l'enchante. Sans les chenilles, le jet urinaire n'eût été qu'une excrétion; il devient instrument de vie et de mort; en face de l'insecte rampant, l'homme qui soulage sa vessie connaît la solitude despotique de Dieu; sans être menacé de réciprocité. Ainsi devant les bêtes féminines, le mâle, du haut de son piédestal, tantôt cruel, tantôt tendre, juste et capricieux tour à tour, donne, reprend, comble, s'apitoie, s'irrite; il n'obéit qu'à son bon plaisir; il est souverain, libre, unique. Mais il faut que ces bêtes ne soient que des bêtes; on les choisira à dessein, on flattera leurs faiblesses, on les traitera en bêtes avec tant d'acharnement qu'elles finiront bien par accepter leur condition. Ainsi les Blancs de Louisiane et de Géorgie s'enchantent des menus larcins et des mensonges des Noirs: ils se sentent confirmés dans la supériorité que leur confère la couleur de leur peau; et si l'un de ces nègres s'entête à être honnête, on l'en maltraitera davantage. Ainsi se pratiquait systématiquement dans les camps de concentration l'avilissement de l'homme: la race des Seigneurs trouvait dans cette abjection la preuve qu'elle était d'essence surhumaine.

Cette rencontre n'a rien d'un hasard. On sait assez que Montherlant admire l'idéologie nazie" (DS 1:333-34).

206 "[U]ne argumentation qui paraît aujourd'hui quelque peu 'facile"' (Zimmerman, "Le mythe de la femme," 191).

207 Montherlant still has his literary defenders, but the guilt Beauvoir alludes to is documented in enormous and convincing detail in Golsan, French Writers and the Politics of Complicity. On Je Suis Partout, see also Alice Kaplan, The Collaborator: The Trial and Execution of Robert Brassilach, especially $3^{2-4}$. Similar parallels between Fascism and misogyny had been drawn by Woolf in Three Guineas, written "with the sound of guns in [our] ears" (2). 
article, "Female Trouble in the Colonial Harem," to which I referred earlier. Apter opens with two epigraphs. The first is from The Second Sex:

He takes great pride in his sexuality only in so far as it is a means of appropriating the Other-and this dream other is abolished as such, it is consumed and destroyed: only the Sultan in The Arabian Nights has the power to cut off each mistress's head when dawn has come to take her from his couch.

The other is from Hélène Cixous' 1975 “Sorties," from La jeune née.

It is in writing, from woman and toward woman, and in accepting the challenge of the discourse controlled by the phallus, that woman will affirm woman somewhere other than in silence, the place reserved for her in and through the Symbolic. May she get out of booby-trapped silence! And not have the margin or the harem foisted on her as her domain!

After the epigraphs, Apter's article proper opens as follows.

In attempting to interpret Western projections of an "other" eroticism in French colonial fiction between 1870 and 1955, one becomes increasingly aware of the uneasy relationship between postcolonial theory and feminist psychoanalysis. Western feminists from Simone de Beauvoir and Hélène Cixous to Gayle Rubin and Sandra Lee Bartky have drawn on the language of apartheid, racism, and colonization to dramatize the worldhistorical situation of women. Economically and socially "enslaved," sexually conquered as "other," placed under the dominion of a despotic Super-phallus identified with the Orientalist sultan, their bodies "trafficked," their voices quelled by the "silence of the harem," feminist critics have qualified their subordination to a phallic regime through the language of colonialism.

There are of course some obvious problems that come with this appropriation of Third World discourse for First World universalizing ends...208

Now, given Cixous's deliberate self-positioning as the antidote to Beauvoir (a favor Beauvoir returned), the choice of epigraphs could be seen as what Tina Chanter was complaining about, the lumping together of writers of disparate

208 Apter, "Female Trouble in the Colonial Harem," 205. 
views to create a seamless feminist genealogy. And I'm not sure that the quotation from Beauvoir means what Apter wants it to mean, since in context, Beauvoir is showing the problem with a (Western) male fantasy. ${ }^{209}$ But both quotations do use Eastern images (the sultan, the harem) to describe woman's unfreedom, and I guess that is close enough: Apter's opening section makes lucid sense, and cogently quotes the relevant authority, Gayatri Spivak, whose "French Feminism in an International Frame" "alerts us to the 'misfiring' of theoretical signifiers in an internationalist context, particularly when those terms blind the reader to cultural and class difference even as they open up to view the history of phallocentric injustice." "This all seems obvious to us now," Apter says, and indeed it does. ${ }^{210}$

209 See my discussion above. Beauvoir is explaining that an authentic sexual encounter poses risks for men, as well as for women, and that fantasies of "possession" are doomed to fail, by the very nature of the sexual act. "Now he will experience the strongest evidence for the ambiguity of his fleshly condition. He can only assume his sexuality with pride insofar as it is a means to appropriate the Other, and this dream of possession only ends in failure. In an authentic possession, the other as such is obliterated, it is consumed and destroyed; but only the Sultan of the Thousand and One Nights has the power to cut off the head of his mistresses as soon as dawn takes them from his bed; woman survives man's embraces, and thus she escapes him; as soon as he re-opens his arms, his prey once again becomes a stranger to him; there she is, new, intact, ready to be possessed by a new lover, in the same ephemeral manner." [Mais c'est alors qu'il va expérimenter avec la plus grande évidence l'ambiguïté de sa condition charnelle. Il n'assume orgueilleusement sa sexualité qu'en tant qu'elle est un mode d'appropriation de l'Autre: et ce rêve de possession n'aboutit qu'à un échec. Dans une authentique possession, l'autre s'abolit comme tel, il est consommé et détruit: seul le sultan des Mille et une nuits a le pouvoir de trancher la tête de ses mâ̂tresses dès que l'aube les retire de son lit; la femme survit aux étreintes de l'homme et par là même elle lui échappe; dès qu'il a ouvert les bras, sa proie lui redevient étrangère; la voilà neuve, intacte, toute prête à être possédée par un nouvel amant d'une manière aussi éphémère $(D S$ 1:271).]

210 For the record, the main target of Spivak's polemic was Julia Kristeva and other poststructuralist French feminists whose work entered the Anglophone world with the 1980 anthology, New French Feminisms, edited by Elaine Marks and Isabelle de Courtivron. Spivak mentions Beauvoir only once: to note (giving credit to Michèle le Dœuff's "Simone de Beauvoir and Existentialism") that the "new French feminists" were making a deliberate break with Beauvoir, just as Althusser and Derrida were writing in opposition to Sartre.

In 1981, when Spivak's article appeared, I was a young graduate student, intimidated by "Theory"; finding it largely incomprehensible, I set the article aside, with the thought that I might return to it when I was older and smarter. Well, I'm older ... and I must admit that parts of it remain opaque to me, for reasons that are probably not the author's fault. However, I find myself in hearty agreement with the parts of it that I do understand, notably Spivak's "dissatisfaction with the presupposition of the necessarily revolutionary potential of the avant-garde, literary or philosophical" (169), and with her long excoriation of Kristeva's Des Chinoises as incoherent, speculative, nostalgic, and condescending. 
What seems odd to me, though, is that Apter never returns to the questions about "appropriation of Third World discourse for First World universalizing ends" with which she began. Her article's real concern is to argue, against Alain Grosrichard, that "the sexual fantasies codified in harem texts may be used to construe an antiphallic, gynarchic model of 'what a woman wants' mediated by cultural difference." She calls for a rethinking of psychoanalysis in the light of these fantasies, and a recuperation of women writers like Isabelle Eberhardt and Myriam Harry as feminist orientalizing writers, who appropriated harem themes "in a feminocentric fashion." She describes this as "subversive" - and the article ends with a discussion of "jouissance" under the sign of Irigaray, Montrelay, and the "new Italian feminism" described by Teresa de Lauretis. This is certainly extremely interesting and may well be quite right (having not read the authors in question, I'm in no position to know). My question is this: how do the two parts of the article fit together? They are joined by a disclaimer, of sorts:

While I do not pretend to have escaped in my own theoretical framings some of the very methodological pitfalls that I have outlined here, I hope at the very least to have introduced a measure of critical selfconsciousness into the discussion of post-colonial interpretation. ${ }^{211}$

This is obviously better than the prophylactic "footnote one" many writers at the "Spelman moment" hastily applied to almost-finished books that had only discussed white women - "more research would be needed to demonstrate whether my conclusions apply across," etc., etc. And both parts of Apter's article are usefully thought-provoking. But I am still having trouble harmonizing the two parts of the argument, absent any synthesizing return at the end. If writers like Eberhardt and Harry can be forgiven for their (quite overt) orientalism, what exactly remains unforgiveable about Beauvoir?

Apter's is a fine article, and I have learned a great deal from her work. My question is what these ritual opening gestures (and they are very familiar ones) really amount to. Does the signifier "Spivak" function as a kind of "open sesame" which gives permission for her argument that some of the texts she is interested in are actually not all that bad, or at least, that the "harem" can be read in more than one way and was sometimes a source of pleasure (if not of

Indeed, now that I have read Des Chinoises (and not simply the rather anodyne excerpts that appeared in Marks and de Courtivron and in The Kristeva Reader), Spivak seems if anything to have understated her case.

211 Apter, "Female Trouble in the Colonial Harem," 206. 
freedom)? (A similar "open sesame" would now require other names: Anzaldúa, Mohanty, Lugones, and so on.) There's nothing at all unreasonable in this. It just seems unfair to blame Beauvoir for not making those ritual gestures, especially since it's not her fault that the gestures she does make (such as bodyslamming Claudel and Montherlant) are inaudible to us now.

But since the door to the harem is now, so to speak, open, let me return to the question of how "Oriental" the harem, by the middle of the twentieth century, even was. I don't want to make too much of the fact that the Collins Robert dictionary now translates the phrase "entouré d'un veritable harem" as "surrounded by a bevy of girls":212 that it has become a "dead metaphor" doesn't mean it's not objectionable. However, for what it's worth, it's possible to collect instances of the word "harem" in Beauvoir's work that don't reference the East at all directly. In the "Woman in Love" chapter of The Second Sex, the term is applied in the middle of a long discussion of Victor Hugo and Juliette Drouethe confined her to a small room and forbade her to go out. ${ }^{213}$ In Les mandarins, Paule uses the term to make a joke about Claudie Belzunce and her group of male lovers, including Scriassine. ${ }^{214}$ In L'Amérique au jour le jour 1947, the harem crops up in the course of a discussion of whether American women really are freer than French women, or only think they are; she concludes that the "demanding and defiant attitude" (attitude de revendication et de défi) she observes in American bourgeoises is simply another mask for their weakness.

Whether she is docile or demanding, man remains the king; he is the essential and woman the inessential; the praying mantis is the antithesis of the submissive harem servant, but both depend on the male. The dialectic of master and slave proves true in this domain as well: the woman who sets herself up as an idol is, in reality, enslaved to her worshippers. ${ }^{215}$

212 Collins Robert French Dictionary, 439.

213 "Despite her efforts to be of service to her idol, the hours were too empty; the seventeen thousand letters she wrote to Hugo, at a pace of three or four hundred each year, testify to that. Between the master's visits she could only kill time. The worst horror, in the condition of the harem woman, is that her days are deserts of boredom; when the male makes no use of the object she is for him, she is nothing." [Malgré ses efforts pour rendre service à l'idole, les heures étaient trop vides: les dix-sept mille lettres qu'elle écrivit à Hugo au rythme de trois cents à quatre cents chaque année en témoignent. Entre les visites du maître, elle ne pouvait que tuer le temps. La pire horreur, dans la condition de la femme de harem, c'est que ses jours sont des déserts d'ennui: quand le mâle n'use pas de cet objet qu'elle est pour lui, elle n'est absolument plus rien ( $D S$ 2:572).]

214 Les mandarins, 1:300.

215 “[À] travers la docilité ou l'exigence, l'homme demeure roi; c'est lui l'essentiel, et la femme l'inessentiel; la mante religieuse est l'antithèse de la servante soumise du harem: tous 
Here she describes the French women, who smile and put up with the moods of their men (toujours prêtes à sourire à leurs mâles et à supporter leurs humeurs), as submitting to the harem; the supposed "praying mantises" are, um, us, or at least us as we were at mid-century. And finally, in Faut-il brûler Sade? Beauvoir uses the term to describe the situation of Justine and her companions. $^{216}$ (The issue here is complex, and I don't want to get off track; but once again the issue seems to be, not "harem" so much as "enfermée.") Surely if a harem can be imposed, not just on French women, but on French women by Christian monks, we could declare the term free of an automatic taint of orientalism, which would release us to listen to what Beauvoir is actually saying.

The fact is, we are hypersensitive now to that one word, "harem." We are no longer in the place where Lorraine Hansberry could extend particular approval to Beauvoir's description of the Tunisian women in the cavelike darkness, or indeed where Beverly Guy-Sheftall could allude to the fact that Anna Julia Cooper "mentioned Muslim harems and the Chinese practice of footbinding on the first page of The Voice of the South" as a sign that Cooper, and other early Black feminists, were "aware of the differential experiences of women" and aiming toward "a broad feminist movement to end all kinds of domination." Guy-Sheftall reads this as a sign of Cooper's internationalism, which I agree with her it was; ${ }^{217}$ I'd be tempted to make the same argument for Hansberry, though the passage feels unfinished to me. ${ }^{218}$ Could we get back to a place where a gesture of ... well, cosmopolitanism (?) would feel refreshing rather than setting off alarm bells? (Are there alternatives to the hermeneutics of finger-pointing?)

deux dépendent du mâle. La dialectique hégélienne du maître et de l'esclave se vérifie aussi dans ce domaine: la femme qui se veut idole est en vérité asservie à ses adorateurs" (AJ 454). See Ruhe, "Femmes, juifs, noirs," 88, for further discussion of this passage.

216 "Faut-il brûler Sade?," Privilèges (1955), 72.

217 "Introduction," Words of Fire, 10. Guy-Sheftall also mentions the Pan-African Congress, organized in Paris in 1919 by W.E.B. DuBois, at which Cooper spoke, and traces other Pan-Africanist strands within the Black women's club movement.

218 Hansberry writes that "when one speaks comparatively of anything, the compared is liable to assume whatever dimensions its opposite does not possess. As long as an observer is able to report passages like the following speaking of our own times, it becomes clearer on what rests the celebrated 'equality' allegedly enjoyed by the American woman...." (And here she quotes, from Parshley, Beauvoir's recollection of the cave-dwellers, "silent and veiled.") Hansberry continues: "Not to even become involved in the variants on the place of women which the world's religions may or may not alter to one degree or another as is the case with Islam, or Christianity, Catholicism or Protestantism, etc., we may still suppose that woman condemned to stay indoors through the hours of light would have been of little use in helping to clear the American fields or sowing grain" ("Simone de Beauvoir and The Second Sex: An American Commentary," 136-37). 
But I certainly wouldn't feel all that comfortable using the term "harem" myself without a good deal of hedging. And I don't think Beauvoir would have had much truck with Apter's argument that the harem was a "gynophilic" space, wherever that harem was located (on Earth, in people's heads, everywhere or nowhere). In volume 2 Chapter IX, "Situation et caractère de la femme," she says

Many of the faults for which [women] are reproached-mediocrity, shyness, pettiness, laziness, frivolity, and servility - simply express the fact that the horizon is blocked for them. Woman, it is said, is sensual, she wallows in immanence; but first she was confined to it. The slave imprisoned in a harem does not feel any morbid passion for rose jelly and perfumed baths: she has to kill time somehow; inasmuch as the woman is stifling in a dismal gynaeceum-brothel or bourgeois home-she will take refuge in material comfort; moreover, if she avidly pursues sexual pleasure, it is often because she has been deprived of it. ${ }^{219}$

(The preceding paragraph ended, "When women are called to concrete action, when they identify themselves with specified goals, they are as strong and brave as men.") 220 Whatever the "gynophilic" pleasures available to the harem woman, or the bourgeois femme d'intérieur, may be, Beauvoir is calling on us to leave them behind.

\section{$9 \quad$ Harem Trouble 2.0: The Veil}

At one time I had intended to conclude this chapter by using Beauvoir's theory to get to grips with French debates over the banning of Muslim headscarves.

219 “Beaucoup des défauts qu'on leur reproche: médiocrité, petitesse, timidité, mesquinerie, paresse, frivolité, servilité, expriment simplement le fait que l'horizon leur est barré. La femme est, dit-on, sensuelle, elle se vautre dans l'immanence; mais d'abord on l'y a enfermée. L'esclave emprisonnée dans un harem n'éprouve aucune passion morbide pour la confiture de roses, les bains parfumés: il faut bien qu'elle tue le temps; dans la mesure où la femme étouffe dans un morne gynécée-maison close ou foyer bourgeois—elle se réfugiera aussi dans le confort et le bien-être; d'ailleurs, si elle poursuit avidement la volupté, c'est bien souvent qu'elle en est frustrée" ( $D S_{2: 491)}$.

220 "Quand on appelle concrètement les femmes à l'action, quand elles se reconnaissent dans les buts qu'on leur désigne, elles sont aussi hardies et courageuses que les hommes" (DS 1:491). 
But the writing of this book has been slow, and events have overtaken it. ${ }^{221}$ What now seems clear (at least to me) is that "the veil" is not one thing, that as an abstraction it is dangerous, that as part of a "mobile army of metaphors" it may be empowering or the opposite, that feminist as well as anti-feminist ideologies are hidden in its folds, that its meaning may be as individual as the woman who wears it, that the power structure which imposes it and the power structure which bans its wearing have an awful lot in common. To borrow again from Annabelle Golay's excellent article: "In Fanon's terms, the veil has 'a historical dynamism."'222 It is tempting to ask where Beauvoir would have stood in these debates, if she had lived long enough to participate in them; tempting, but probably dangerous. As she said in Pour une morale de l'ambiguité, one can never know how one's project will be taken up by others. Still, as I said in my introduction, Beauvoir remains the terrain on which we play out our own arguments about feminism, about the history of feminism, and (in this case) about the relationship between gender and colonialism, since it is impossible to understand France's relationship to its non-white population today apart from its relation to its former colonies. (As British campaigners put it, "we are here because you were there.") And it may be illuminating to see how Beauvoir's legacy has been (once again) invoked to justify two irrevocably opposed and deeply held political positions.

At the height of the debate, Christine Delphy, who is Beauvoir's heir on the materialist side, published a book arguing against the headscarf ban, which she saw as racist and Islamophobic, similar to "feminist" arguments made by the American government in favor of the war in Iraq. ${ }^{223}$ But at the Paris conference in January 2008 celebrating the centenary of Beauvoir's birth, the French organizers announced that a prize in Beauvoir's honor had been awarded to Ayaan Hirsi Ali, the self-styled "Voltaire noire," whose position appears to be that Muslim women do need saving, and that Western enlightenment values

221 For a good summary of the intractable issues involved, see Yasmin Rehman, "How have we come to this?" (reviewing Delphy, Separate and Dominate: Feminism and Racism After the War on Terror): "Very few issues attract as much attention or public discussion as the niqab or face veil. Is it a symbol of oppression or of minority women asserting their religious identity? In 2004, when France became the first country in Europe to introduce legislation banning the wearing of religious symbols in schools, the law was initially presented as a matter of laïcité and what it means to be French. This ban in schools was later extended to wearing of the hijab in public spaces in 2007. It was followed by a ban on face coverings in 2011 based on security concerns." See also Joan Scott, The Politics of the Veil.

222 "Il existe donc, selon les termes de Fanon, 'un dynamisme historique du voile"' (Golay, "Féminisme et postcolonialisme," 412).

223 Delphy, Separate and Dominate. See also the 2006 special double issue of Nouvelles Questions Féministes. 
will rescue them from the backwardness and violence of Islam. Hirsi Ali is an enormously polarizing figure. At that time she was already controversial because, while a member of parliament in the Netherlands, she had supported restrictions on immigration, including opposing the law that had made it possible for her to gain asylum and then citizenship there herself as a refugee from Somalia. As a result of these public stances she had been embraced by thinkers who are clearly right-wing, such as the Hudson Institute in the US. ${ }^{224}$

The prize committee was headed by Julia Kristeva, who also organized the conference. Despite Kristeva's earlier position in "Women's Time" that the Beauvoirian feminism of the "project" had been (or ought to be) superseded by a poetic restructuration of the Symbolic, now she seems to embrace Beauvoir's legacy, while continuing to disagree with a major part of it by insisting on women's "difference" as underwritten by a Lacanian Oedipus and rooted in "the maternal" - a disagreement that Beauvoir would hardly have considered trivial. Nonetheless, there she was. The prize committee also included Elisabeth Badinter, whose position on the question of "the maternal" is just the opposite of Kristeva's: Badinter's book, Fausse route, makes a strong critique of the maternalist and essentialist strain in French feminist thinking, and claims the mantle of Beauvoir in this (I think rightly, though she exaggerates Beauvoir's view); Kristeva is more accurate when she describes her own position on "the maternal" as a departure from, and a criticism of, Beauvoir, though her claim that her departure is an advance on Beauvoir is not one I can accept. ${ }^{225}$ Given their opposite positions about essentialized and biologized "difference," it is hard for me to imagine how Kristeva and Badinter can sit down at the table together, but in affirming the heroic status of Ayaan Hirsi Ali they seem to have found common ground.

Kristeva's prize-giving speech endorsed some positions of Hirsi Ali's that raise red flags with respect to the racial and national situation of women (and men) in Europe today. Focusing on Beauvoir's prioritizing of "freedom," Kristeva noted that Hirsi Ali "has written numerous articles denouncing the dangers

224 The prize was also given to Taslima Nasreen, a less well-known writer who has also been critical of the Islamic milieu in which she was raised. See Kristeva, "Beauvoir aux risques de la liberté."

225 Ibid. Kristeva's rather condescending statement (in her prize-giving speech) that Beauvoir did not have access to the insights of psychoanalysis seems particularly obtuse: as we've seen, she did have access to them and lucidly rejected their normalizing and biologically deterministic underpinnings. From the perspective of anyone convinced by Judith Butler's exposure in Gender Trouble of the heteronormative grounding of Lacan's theories and of their uptake by the "new French feminists," it would seem to be Kristeva who is "behind the times" here, but never mind. 
of communalism, which she considers an obstacle to integration, and calling for a period of Enlightenment for European Islam," and describes her as "a woman passionately engaged in favor of effective interaction between women of immigrant origin, especially Muslims, and European society."226 Terms such as "integration" and "communalism" (communautarisme) may seem innocuous, but in context they are code words indicating Hirsi Ali's support for policies that have led to closed borders, lack of respect for cultural difference, and (it is at least arguable) Islamophobia. (And one might ask what "effective interaction" even means: on whose terms is this interaction to take place?)

Kristeva's position in the sphere of real-world politics (including feminist politics) has always been ... difficult to map (to put it as charitably as I can). ${ }^{227}$ But Elisabeth Badinter, who has a platform as a prominent public intellectual in France, has been an outspoken opponent of multiculturalism there. Elsa Dorlin points in particular to the fact that, when invited by French legal authorities to speak about the burka, Badinter called it the worst expression of sexism, saying "France has to protect women who want to wear une jupe (a skirt)." ${ }^{228}$ Badinter has spoken, not just in defense of laïcité (state secularism)

226 "Elle est l'auteur de nombreux articles dénonçant les dangers du communautarisme, qu'elle considère comme un obstacle à l'intégration, et réclame pour l'Islam d'Europe une période des 'Lumières' ... une femme passionnément engagée en faveur d'une interaction effective entre les femmes issues de l'immigration, en particulier musulmane, et la société européenne" (Kristeva, "Beauvoir aux risques de la liberté," 15).

227 It is hard also to square this praise of the self-described "Black Voltaire" with the "concerted epistemic critique" of "Enlightenment rationality" through which Kristeva and her collaborators on $\mathrm{Tel}$ Quel rose to fame.

228 Elsa Dorlin, "The Future of Intersectionality," delivered at 2009 Symposium at NYU titled "Feminism/s Without Borders?: Perspectives from France and the US." See also Thomas Lancelot, writing in Le Monde: "Nonetheless, [Badinter] has quite consistently declared: 'Frankly, for a long time, in mainstream [de souche] French society, whether Jewish or Christian, one cannot say that women are oppressed' (L'Arche, November-December 2003). Her honesty has the merit of drawing a line in the sand. What do French women have to complain about since they are neither oppressed nor disadvantaged? The feminist struggle is not addressed to them, but 'to the young women of the first generation of new arrivals, or young women of Maghrebi origin. It is for them that one must carry on the struggle.' So, patriarchy is still rife 'down there,' in Arab and African countries, or here at home but only on the outskirts (banlieue) among men and women who come from 'down there,' but not really 'here at home,' not in the French Republic." [Par ailleurs, conséquente avec elle-même, [Badinter] a déclaré: "Franchement, depuis longtemps, dans la société française de souche, que ce soit le judaïsme ou le catholicisme, on ne peut pas dire qu'il y ait une oppression des femmes" (L’Arche, novembre-décembre 2003). Sa franchise a le mérite de mettre les pieds dans le plat. De quoi se plaignent les Françaises puisqu'elles ne sont ni opprimées, ni discriminées? Le combat féministe ne s'adresse pas à elles mais "aux jeunes femmes de la première génération de nouveaux arrivants, ou encore aux jeunes 
but in favor of specifically French values, of the "French exception" and "la France de souche," France at its origin, the rootstock of France.

Now, the idea that some French people are "français de souche" (and that others are not) is a very old idea-it is Barrès, it is Maurras. It was used against Jews ("rootless cosmopolitans" that we were and are); it was what slapped Frantz Fanon in the face when he served in the French army; and it seems to be alive and well today. (Look, a Muslim!) It is a very powerful idea — even Simone Weil fell for it. ${ }^{229}$ But Simone de Beauvoir, as we have seen, did not fall for it, and to use her name (and her legacy) to sanction it is a bit breathtaking.

Kristeva spoke of Beauvoir's commitment to freedom-the name of the prize, in fact, is "Le prix Simone de Beauvoir pour la liberté des femmes." And of course Beauvoir was unabashed in her support of "freedom," but to say so is merely to kick the can down the road, since "freedom" means quite a few different things: its mobilization by US foreign policy (remember "freedom fries"?) is particularly gruesome to contemplate. Kristeva was right also to say

filles d'origine maghrébine. C'est pour elles qu'il faut le conduire" (ibid.). Le patriarcat sévirait donc ailleurs, "là-bas," dans les pays arabes et africains, en Iran et en Afghanistan, ou chez nous, mais seulement en banlieue chez les hommes et les femmes originaires de "là-bas," mais pas "chez nous," pas dans la République française (Lancelot, "Elisabeth Badinter fait fausse route.")]

See also Mehamed Amadeus Mack, Sexagon:Muslims, France, and the Sexualization of National Culture, 293: "Badinter is infamous, in some circles, for declaring that her conclusions about the 'fragility' of masculinities in Western society do not apply to men outside of Western civilizations, and that, if she calls for increased tolerance for the expression of masculinity at all, it is not for the excessive virilities of non-European men who haven't been subjected to the same 'emasculation.' This analysis echoes right-wing psychoanalyst Michel Schneider's comments on immigrant men." Badinter's concern for young Muslim women must be seen against the backdrop of her dismissal of many positions we would consider feminist - for instance, she denounced the Clarence Thomas hearings as a "witch hunt," and much of Fausse route makes arguments against so-called "victim feminism" that parallel those of Christina Hoff-Sommers and Katie Roiphe. This is also oddly connected to anti-Americanism: see Eric Fassin, "The Purloined Gender." (Fassin's quotation about Clarence Thomas comes from Le Nouvel Observateur, October 1723, 1991). Among Badinter's many inconsistencies is her insistence that feminism itself is an American export and therefore "un-French." An English translation of Fausse route was published by Polity Press in 2006 (with the assistance of the French Ministry of Culture), under the title Dead-End Feminism. Or at least, this purports to be a translation, but it is 126 pages long, whereas the French original was 221 pages. I'm not sure any purpose would be served by going into this further, or explaining what a terrible book it indeed is.

229 See Simone Weil, L'enracinement. Apparently even Léopold Senghor fell for it: David Macey describes him as "influenced by the nationalism of Maurice Barrès, who defined the French national identity in terms of fidelity to the land and its dead" (Macey, Frantz Fanon, 179). 
that no one owns Beauvoir's legacy: "Whatever the merits of those who are inspired by the works of Simone de Beauvoir, no one, neither friend nor scholar, can stand in for her or claim a monopoly on them."230 But as Michèle le Douff remarked in a different context, some things are just too much. ${ }^{231}$ If Badinter's idea of "freedom" purports to be a reading of "what freedom is possible to the woman in a harem," it is a lamentable distortion.

Among those who were horrified on the spot by this misappropriation of Beauvoir's mantle was Beauvoir scholar Karen Vintges, who, since she is herself Dutch, had a more acute sense than most of those present of who Ayaan Hirsi Ali even was. Protesting the prize in a later article written with Bart van Leeuwen, Vintges argues forcefully against placing Beauvoir in the tradition of Enlightenment "liberal" thinking. ${ }^{232}$ The question Vintges and van Leeuwen ask is "whether Beauvoir's work is open to a politics of difference from the position of oppressed or marginalized groups, or whether her work endorses liberal feminism, as claimed by Badinter and others."233 And they make a good textual case for the former view. It is easy to find support for the authenticity of socially-grounded minority identities in L'Amérique au jour le jour 1947, and to discover scorn for liberal constructions of the self in Pour une morale de l'ambiguité. As Vintges and van Leeuwen point out, Beauvoir there criticizes the Enlightenment dream of reason as "hollow"; absolute universal man, she says, exists nowhere, nulle part. ${ }^{234}$ It must be said, too, though, that Beauvoir never abandoned belief in universal human rights, in the Amnesty International sense of human rights, and that for her as for most people, such rights include bodily autonomy and self-development.

But I think we can answer Badinter and Kristeva in a less abstract way. Whatever may be true in the abstract about "liberal individualism," Pour une morale de l'ambiguité clearly requires us to inform ourselves about the actual political stakes of what we say and do, at the moment and in the place that we

230 "[Q]uelles que soient les qualités de celles et ceux qui s'inspirent de l'œuvre de Beauvoir, personne (ni ami ni spécialiste) ne l'incarne ni n'en possède le monopole" (Kristeva, "Beauvoir aux risques de la liberté," 11).

231 "In 1986, the Italian Communist Party asked me to lead a debate in Milan with Marisa Rodano on Simone de Beauvoir, in which Marisa was to say that The Second Sex is not a feminist book. I protested: of course, many misunderstandings of Simone de Beauvoir's work are possible, but that is just too much" (Hipparchia's Choice, 47).

232 Bart van Leeuwen and Karen Vintges, "A Dream, Dreamed by Reason ... Hollow Like All Dreams: French Existentialism and its Critique of Abstract Liberalism." See also Vintges, "Surpassing Liberal Feminism," and A New Dawn for The Second Sex: Women's Freedom Practices in World Perspective.

233 van Leeuwen and Vintges, 655 .

234 PMA 162, EA 112. 
say and do it. The effect of awarding the prize was to legitimate Hirsi Ali as a feminist voice, and to ally international feminism with the forces of reaction. Beauvoir would never have endorsed Hirsi Ali because she would have found the idea of closed borders, and the argument for the superiority of European (read, white) culture morally, and historically, repugnant. Moreover, as I hope I have shown, Left and Right were meaningful terms to her, and she would have done the math, and come out with a different answer than Badinter's.

In fairness, this is clearer now than it was in 2008 , though all the signs were there.

Hirsi Ali is at present such a polarizing figure that I am unable to cite a neutral source about her and can only summarize the situation by giving a range of views. She has certainly stated publicly that Islam is an intrinsically violent religion and has endorsed the Huntingdon doctrine of the "clash of cultures"; this has endeared her to the American Enterprise Institute and other clearly rightwing groups in the US. She has repeatedly endorsed restrictions on immigration and requirements that immigrants assimilate to Western culture. Meanwhile, some on the left have gone as far as to assert that Hirsi Ali's powerfully moving story of her own abuse in the name of Islam (including a forced marriage from which she heroically escaped) is a fabrication. ${ }^{235}$ The well-respected and usually reliable Southern Poverty Law Center accepts these claims, and includes Hirsi Ali (along with David Horowitz and Charles Murray) in its "Field Guide to Anti-Muslim Extremists." Both Blumenthal and the SPLC were vitriolically attacked at the time (2015) by Hirsi Ali herself, and she was supported by right-wing outlets such as the National Review, which attempted to demonize the SPLC. As I said, I am not in a position to independently judge any of this. Around the same time Rula Jebreal, writing in Salon, did not contest the facts of Hirsi Ali's own life story, but made a reasonable-sounding case that in the current political climate her views, and their prominence in mainstream media, were causing harm to moderate Muslims like herself. Her headline read: "Ayaan Hirsi Ali is dangerous: Why we must reject her hateful worldview. To endorse Hirsi Ali-as pundits everywhere from Fox News to network news have-insults and mocks a billion Muslims."

It would appear from recent coverage in mainstream media that Hirsi Ali has won her argument against those who question her story; she is still considered "mainstream" enough to have a platform from which she has attacked Western feminists, including in The New York Times. In 2017 she cancelled a book tour to Australia after a group of Muslim women there protested that she did not speak for them: according to the Guardian, the women had "criticized

235 See in particular Max Blumenthal, "Exposing Hirsi Ali's Latest Deception." 
her for past descriptions of Muslim women as docile and irrational, accused her of using the language of white supremacists and profiting from 'an industry that exists to dehumanize Muslim women'”; Ali replied by accusing them of "'carrying water' for radical Islamic organizations like the Muslim Brotherhood, Islamic State and Boko Haram, and stated that 'Islamophobia is a manufactured term."' Make what you will of all this: it's certainly clear what the stakes are.

I am honestly not sure whether it is legitimate or not to say, hmm, the Southern Policy Law Center is against her, and she's been defended by the National Review ... I'll go with the Left answer. But I am sure that it is a kind of reasoning with which Beauvoir would have been very comfortable: the ethical engagements one undertakes are undertaken with others, she says, and despite the importance of maintaining one's intellectual independence, it is no small matter to rethink such shared projects. The supposedly disinterested, disengaged intellectual who pretends to be above the fray ("both sides commit abuses ... perhaps the truth lies somewhere in between ... it's too early to judge") is a particular target of her scorn in Pour une morale de l'ambiguité.

However, it's easier to see why Hirsi Ali and Badinter are wrong than to decide what a reasonable feminist position would actually be. Beauvoir's theory can perhaps help us here, but only up to a point. Yasmin Rehman, in summing up the issues, quotes Meredith Tax in terms strikingly reminiscent of the dilemmas posed in Pour une morale de l'ambiguïté:

When US diplomats invoke the oppression of Muslim women to sanctify war, how do we practice feminist solidarity without strengthening Orientalism and neo-colonialism? When the US targets jihadis for assassination by drone, should human rights defenders worry about violence perpetrated by those same jihadis or focus on violations by the state?236

One answer to this particular question, based on Beauvoir's attitude during the Algerian crisis, might be that we should focus first on the wrong our own governments are doing, since that violence is undertaken in our names, whatever excuse may be given. Harder to answer is a question with a similar shape, as laid out by Traci West in her good article about Fanon:

236 Meredith Tax, Double Bind: The Muslim Right, The Anglo-American Right, and Universal Human Rights, quoted in Rehman, "How Have We Come to This." "Conversely," Rehman continues, "how does one raise the points discussed by Delphy with regard to the war on terror, drone strikes, Guantanamo, and the denial of any discussion about the real or perceived causes for terrorism, without feeding the Islamist agenda and reinforcing the Muslim victim narrative?" 
Because of the colonizer's campaign against it, the practice of wearing the veil became an important symbol of resistance within the struggle for independence. [Marie-Aimée] Hélie-Lucas articulates the problem that resulted for Algerian feminists who wanted to criticize this practice: "how, therefore, could we take up the veil as oppressive to women without betraying the nation and the revolution?"237

I think Beauvoir would have refused to answer this question, just as she refused to pass judgment on Richard Wright for refusing to support the war effort of the US government, or on the colonized people who did not fight alongside the Allies. Here both sides of the dilemma do have merit, the demands are indeed incompatible, and it is for them to decide. As Pour une morale de l'ambiguité reminds us, there are no recipes.

But the veil in Algeria and the veil in France are different matters; and about the latter, she might well have felt the need to take a position, since it was, in fact, the actions of her own government that were in question. She would certainly have detected the hypocrisy and bad faith of a policy that, under the banner of "secularism" and civic education, banned Muslim "insignia" while continuing to permit the display of Christian and Jewish insignia-for example, the wearing of a cross around the neck. Her own secularism was absolute, and it was hard-won. ${ }^{238}$ And overall, I think she would have agreed with Elsa Dorlin that "intersectionality should not be an alibi, or substitute for politics of resistance." ${ }^{239}$ In a late interview with Hélène Wenzel, the latter raised the issue of women of color critiques, with particular reference to the issue of female genital mutilation. Here is the exchange.

Wenzel: In the States over the last decade, there has been a large increase in the numbers of voices raised, and in the writings emerging, from women of color. Both individually and collectively, these loud, clear, and multiethnic voices have sought to remind us - white, predominantly university women who too often think we speak for all women and who define

237 Traci West, "Extending Black Feminist Sisterhood in the Face of Violence: Fanon, White Women, and Veiled Muslim Women," 176.

238 The communal "culture" that comes in for the greatest excoriation in The Second Sex is clearly Christianity, in particular Catholicism. Let's not forget that The Second Sex was on the Index for many years, and that one of her own teachers wrote a book denouncing her from a devout, orthodox perspective. Republic or no Republic, the world Simone de Beauvoir grew up in had elements of theocracy: we may find this hard to see but she did not.

239 Elsa Dorlin, "The Future of Intersectionality." La force des choses also contains, at various points, a forthright attack on what the English call "what-about-ery." 
feminism in our writings - that the women's fight is much more complex than either we, Betty Friedan or Ms. magazine seem to think it is, and write about it. Is there a similar situation in France, have other voices, other writings begin to manifest themselves?

De Beauvoir: There aren't many, there aren't many women who speak.... Yes, there have been women who have spoken, for example, about the problem of excision (clitoridectomy), which is a particularly African problem and there have been a number of books about this ... there have been groups, both Western and African, who have met to combat the problem of excision. And there is presently much talk about this problem.

Wenzel: That is very interesting, because in the States, some women have begun to write and to speak out against these manifestos decrying excision. There are Black women, and African women who have begun to say that for Western women to look at African women's problems....

De Beauvoir: It has nothing to do with Western women, yes, that's it. I've heard that. But there are nevertheless African women who say that the problem belongs as much to Western women as to others, because it's a question of human rights.

Wenzel: Exactly.

De Beauvoir: And it's not a question ... and there's a kind of racism, on the contrary, in not wanting to look at these sorts of conditions.... Because that means that deep down one doesn't care what happens to little black girls, and there are about thirty thousand a year who undergo excision, and to find that trivial, finally, not to deal with that, that proves that we think it's fine for them, naturally. We don't want any part of it. And it's much more feminist, logical and universal, and not racist, to be involved in these sorts of questions. ${ }^{240}$

(I'm not unaware of post-colonial and feminist critiques of the discourse of "universal human rights." As I was writing this paragraph, Donald Trump pulled the United States out of the UN Human Rights Council. Perhaps we'll soon get to find out more about what a world without that "discourse" will look like.)

Sorry, carry on. In any case, Beauvoir's point about "excision" was that African women were opposed to it; they were, and they are. In the passage I used above from Tout compte fait, where she sees that Fanon was mistaken when he

240 Hélène Wenzel, "Interview with Simone de Beauvoir," 16. This is the same interview where Beauvoir wished to speak of matters going beyond her feminist works, but Wenzel did not. 
thought women would be freed by the Algerian revolution, she refers to "a courageous Algerian woman who has written a book"- though I do not know which woman and which book she means. Perhaps it is worth returning to that passage in its entirety; what emerges is how fully her thinking about "women's position" is embedded in a fact-based, complex understanding of the broader picture, including its paradoxes and tragic ironies.

A disappointment of another kind was the evolution of Algeria. Of course no one could look for a miracle that would suddenly bring about the reign of socialism and prosperity: the war had killed more than a million people; the finest leaders had been killed in the guerilla fighting; and the departure of a million Europeans [pieds-noirs] who ran the country left it in economic confusion. At the time when the Algerians won their independence, eighty-five percent of the adults were illiterate. The reorganization of the economy could not fail to be a difficult task. The disaster foretold by the colonialists did not occur; but a third of the male working population is under-employed, another third unemployed altogether, and five hundred thousand have emigrated. The circumstances were unfavorable for the setting up of socialism, but the leaders have made no serious effort in that direction whatsoever. What they have done is to install a state capitalism that has nothing socialist about it apart from the name. In agriculture they have not encouraged the collectivization of the land; in industry they have not encouraged management by the workers. Instead of attempting to make the masses politically conscious they have urged them to return to the values of the Arab, Islamic world. Unlike Tunisia and Egypt, Algeria has made no attempt at checking the birthratea birthrate so high that the population is increasing far more rapidly than its resources. The condition of women is deplorable and one of them has spoken out about it in a courageous book. They are given no more than a minimum of education, and this is justified by Muslim tradition; they still wear veils; and they are confined either to their father's home or to that of the husband they are obliged to marry. Fanon was profoundly mistaken when he foretold that the Algerian women would escape from male oppression because of the part they had played in the war. Algeria's foreign policy is held out as "progressive" and it is indeed anti-colonialist and anti-imperialist. But the country's home policy is both nationalist and reactionary. There is nothing to show that it is likely to change its nature for a very long while. ${ }^{241}$

241 This analysis, and indeed these developments, are in line with Fanon's own predictions in Les damnés de la terre that post-colonial society might actually not be much better than 
And such changes as have occurred there since, she would hardly have welcomed.

Beauvoir certainly had no love for "the veil" as such, and sometimes, as here, she takes it as one index of women's subjugation and exclusion. Edward Said himself has reported another such instance, in a rather mean-spirited account of his disappointment upon meeting Sartre and Beauvoir in 1979. The meeting was instigated by the Temps Modernes team, though it took place in Foucault's apartment. ${ }^{242}$ Said had been hoping for a statement from Sartre denouncing Zionism and expressing support for the Palestinians, but found the written result of the dialogue disappointingly tepid, and described Sartre as mentally extinguished by age and illness and as manipulated by his acolyte, "Pierre Victor" (Benny Lévy).

Beauvoir was already there in her famous turban, lecturing anyone who would listen about her forthcoming trip to Teheran with Kate Millett, where they were planning to demonstrate against the chador; the whole idea struck me as patronizing and silly, and although I was eager to hear

what it replaced. “Une déception d'un autre ordre, c'est celle que m'a fait éprouver l'évolution de l'Algérie. On ne pouvait certes pas escompter qu'un miracle y ferait régner dans un bref délai le socialisme et la prospérité; la guerre a fait plus d'un million de morts, les meilleurs cadres ont été tués dans les maquis, le départ d'un million de pieds-noirs qui contrôlaient le pays l'a laissé dans une situation économique confuse. Le jour où l'indépendance fut conquise, $85 \%$ des adultes étaient analphabètes. La réorganisation de l'économie ne pouvait être que difficile. Les catastrophes prédites par les colonialistes ne se sont pas produites. Mais un tiers de la population masculine active est sous-employé, un tiers sans emploi: cinq cent mille travailleurs ont émigré. Les circonstances n'étaient pas propices à l'établissement du socialisme; mais les dirigeants n'ont fait aucun effort sérieux en sa faveur. Ils ont instauré un capitalisme d'État qui n’a de socialiste que le nom. En agriculture ils n'ont pas encouragé la collectivisation des terres; dans le secteur industriel, ils n'ont pas poussé les travailleurs à l'autogestion. Au lieu d'essayer de politiser les masses, ils les ont incitées à revenir aux valeurs arabo-islamiques. Contrairement à ce qui se produit en Tunisie, en Égypte, aucun effort n'a été fait pour ralentir une natalité galopante telle que la population s'accroît beaucoup plus vite que les ressources. La condition des femmes est déplorable: une Algérienne l'a dénoncée dans un livre courageux. Au nom de la tradition musulmane on ne lui accorde qu'un minimum d'éducation; elle continue à porter le voile, elle est confinée dans le foyer de son père ou du mari qui lui est imposé. Fanon s'est bien trompé quand il prédisait que grâce au rôle qu'elles ont joué pendant la guerre les femmes algériennes échapperaient à l'oppression masculine. La politique extérieure de l'Algérie se veut 'progressiste'; elle est anticolonialiste et anti-impérialiste. Mais à l'intérieur elle est nationaliste et réactionnaire. Rien n'indique qu'elle doive avant bien longtemps changer de caractère" (TCF 561-62, ASD 442-43).

242 This at first struck me as odd, given that Sartre and Foucault are positioned as antagonists in the usual story about "French theory." However, where practical politics were concerned, they often signed the same manifestos, and were photographed at the same demonstrations ... Here, a "sustained epistemic critique" had emerged. And yet... 
what Beauvoir had to say, I also realized that she was quite vain and quite beyond arguing with at that moment. Besides, she left an hour or so later (just before Sartre's arrival) and was never seen again.... Beauvoir had been a serious disappointment, flouncing out of the room in a cloud of opinionated babble about Islam and the veiling of women. At the time I did not regret her absence; later I was convinced she would have livened things up. ${ }^{243}$

The sexism here speaks for itself. ${ }^{244}$ Beauvoir's own account of the meeting with Said is considerably more generous; she agrees that Benny Lévy's attempt at "dialogue" was pointless and ineffectual, but sticks to the facts. ${ }^{245}$ (This is

243 Said, "Diary." For some reason this story recirculates gleefully through the blogosphere from time to time. See Eugene Wolters, "A Bitter Disappointment," and Yasmin Helal, "Edward Said Recalls His Depressing Meeting." For a riposte, see Shiraz Socialist, "Anti-Orientalist Meets Western Feminist."

244 I am afraid the dismissive attitude toward women intellectuals on display here is not contradicted by my own memories of Said, whose office at Columbia was across the hall from mine in my grad school days. His obituary by friend Alexander Cockburn ("Edward Said: A Mighty and Passionate Heart") includes the phrase, "even in his pettiness he was magnificent"; I too remember the rages over small matters Cockburn describes (the walls of Hamilton Hall were hardly soundproof), but their "magnificence" eluded me. None of which, of course, does anything to tarnish his pioneering intellectual and political contribution or diminish the fact that his death was a sad loss to the world of letters.

245 "The speeches were more or less interesting, more or less touching, but in general it was always the same old story - the Palestinians wanted a territory of their own and the Israelis—all chosen from the Left—agreed, but they wanted their security guaranteed. In any event, these people were intellectuals who possessed no kind of power at all. Victor was nevertheless exultant. 'It's going to be an international scoop,' he told Sartre. He had to eat his words. For various reasons the issue, entitled 'Peace Now' after an Israeli pacifist movement that did not play any great part in politics, only appeared in October, and it fell flat. During the summer of 1980. Edward Said, whom Victor looked upon as the member of the conference with the greatest prestige, told some common friends that he did not understand why he had been made to come from America. The meeting had seemed to him a wretched affair while he was attending it, and even worse when he read the proceedings. But in March 1979 Sartre shared Victor's optimism, and I did not tell him about my doubts" (Adieux, 113-14). [Les interventions furent plus ou moins intéressantes, plus ou moins émouvantes, mais en gros c'était toujours la même rengaine: les Palestiniens réclamaient un territoire, les Israéliens-tous choisis à gauche-étaient d'accord mais exigeaient des garanties de sécurité. De toute façon, il s'agissait là d'intellectuels qui n'avaient aucun pouvoir. Victor n'en jubilait pas moins: "Ça va être un scoop international," a-t-il dit à Sartre. Il a dû déchanter. Pour diverses raisons, le numéro intitulé "La paix maintenant"—du nom d'un mouvement israélien pacifiste qui n'a pas joué un grand rôle politique—n'a paru qu'en octobre et est tombé à plat. L'été 8o, Edward Saïd—qui était aux yeux de Victor le membre le plus prestigieux du colloque-a dit à des amis communs qu'il ne comprenait pas pourquoi on l'avait fait venir d'Amérique: le colloque lui avait 
not the place to explore the developing attempts of Les Temps Modernes and of Lanzmann himself to find middle ground from which to support both the Palestinian cause and the existence of the state of Israel; as with Sartre's earlier involvements with the French Communist Party, the resulting positions would appear to have satisfied no one. ${ }^{246}$ )

In a different context, Lanzmann's autobiography shows Beauvoir as unafraid to confront Muslim men about the position of women in their own countries. ${ }^{247}$ But Kate Millett's account in Going to Iran describes a rather different and more complex motivation for the trip, on which Beauvoir was ultimately too ill to accompany her, than Said's dismissive summary conveys. Millett had been working with a (mixed gender) group of young Iranians who opposed the repression of the Shah, touring American campuses to build support for attempts to topple the regime. When the revolution finally came, that group invited her to come to Tehran (and bring others) to bear witness and

paru minable sur le moment même, et davantage encore quand il en avait lu le compte rendu. En mars 79, cependant, Sartre partageait l'optimisme de Victor, et je ne lui ai pas fait part de mes doutes (La cérémonie des adieux, 160).]

246 Around the time of the Six-Day War, Beauvoir wrote, "I was not in complete agreement with any of my friends.... As a result of my positions on the Middle East question, I almost always feel in an awkward position in my relations with leftist militants. I am entirely for the Black Panthers and I admire Cleaver's book, Soul on Ice; but I was deeply depressed when he attacked the Jews in his Temps Modernes interview. I regret that the Left should have grown almost as monolithic as the Communist Party. A leftist must necessarily admire China without the least reservation, take Nigeria's side against Biafra and the Palestinians' against Israel. I will not bow to these conditions. Which doesn't prevent me from feeling very close to the leftists on the terrain that most closely concerns them, in the action they carry out in France" ( $A S D$ 436-37, translation altered). [Avec aucun de mes amis je ne me suis trouvée en parfait accord.... À cause de mes positions sur la question du Moyen-Orient, je me sens presque toujours en porte à faux dans mes rapports avec les militants de gauche. Je suis de tout cœur avec les Panthères noires, j'admire le livre de Cleaver, Soul on Ice; mais cela m'a attristée que dans l'interview qu'ont publiée Les Temps Modernes il s'attaque aux Juifs. Je regrette que le gauchisme soit devenue presque aussi monolithique que le parti communiste. Un gauchiste doit admirer inconditionnellement la Chine, prendre parti pour le Nigeria contre le Biafra, pour les Palestiniens contre Israël. Je ne me plie pas à ces conditions. Ce qui ne m'empêche pas d'être très proche des gauchistes sur le terrain qui les concerne le plus directement: l'action qu'ils mènent en France (TCF 553-554).]

247 Shortly after Fanon's burial, Lanzmann remembers, the Évian accords were signed and he was able to visit Algerian leaders who were being held in Fresnes prison, including Mohamed Boudiaf and Ahmed Taleb Ibrahimi. "The prisoners enjoyed considerable autonomy within Fresnes Prison. After they were freed, we took them in for several days. Taleb, as I have mentioned, stayed with my sister Évelyne; others stayed with me. Simone de Beauvoir attempted to persuade them to abandon polygamy, and they let her talk" (Claude Lanzmann, The Patagonian Hare, 347-48). 
show support; as the revolutionary movement was coopted by fundamentalists, Millett and her companion were caught in the crossfire and expelled from the country. ${ }^{248}$ Beauvoir's own attitude toward the trip is highlighted by Janet Afary and Kevin Anderson, in their book about Foucault's support for the Iranian revolution. They reprint the complete text of the speech Beauvoir delivered in March 1979 at a press conference in Paris, announcing the international delegation's departure for Teheran. Beauvoir emphasizes that the team has been invited by Iranian feminists to come and show their support. Most of the brief text is devoted to making clear that the main purpose of the trip is to gather information.

We have created the International Committee for Women's Rights (CIDF) in response to calls from a large number of Iranian women. Their situation and their revolt have greatly moved us. We have decided to create this committee, which has set itself several tasks. The first one is information. It is a matter of becoming informed about the situation of women across the world, a situation that to a very, very great extent is extremely difficult, painful, and even odious. Therefore, we wish to inform ourselves, in very precise cases, of this situation.

We then wish to inform others of it; that is, to communicate the knowledge that we have gained by publishing articles. And finally, we wish to support the struggle of the women who fight against the situation that affects them. That is the general idea of the CIDF.

The first task we have taken up is a very, very burning one for today. It is the task of acquiring information concerning the struggle of the Iranian women, communicating that information, and supporting their struggle. We have received an appeal from a very large number of these women. We have also seen their struggles, their fights, and their actions. We have appreciated the depth of their utter humiliation into which others wanted to make them fall, and we have therefore resolved to fight on their behalf.

Thus, the first practical step that will make our call to action concrete is a specific one. We are sending a women's delegation to Tehran, in order to gather information. We have sent a telegram to [the Iranian prime

248 Going to Iran is written in the characteristic moment-by-moment cinéma vérité style Millett first developed in Flying and put to good use in The Loony-Bin Trip and elsewhere. Some readers may find this experiment in radical honesty irritating — do we really need to know that Kate and Sophie cannot find their laundry bag? - but her use of it is consistent and principled, and there is no reason to doubt her account of unfolding events. 
minister] M. Bazargan, asking him if we will see us. I say "we," although for personal health reasons, I am not going. But I have many women friends who are going to travel to Iran on Monday. We have asked him to receive the delegation, but even if he does not reply, we are going anyway! In that case, however, it would no longer be a dialogue with a head of State. It would solely be an effort to gather information. Unless, of course, they turn us away completely, which is still a strong possibility. It is very possible that the mission will fail, inasmuch as they might turn it away the moment it arrives. Nevertheless the die will have been cast, and it is important to have a demonstration - on the part of a very large number of Western women, French women, Italian women, and others-of solidarity with the struggle of Iranian women.

I reiterate, however, that this is essentially an effort to gather information, in order to put ourselves in contact with Iranian women, in order to know their demands and the ways in which they plan to struggle. ${ }^{249}$

As Karen Vintges comments, "[Beauvoir] thus emphasized the need to support Iranian women from their point of view, instead of imposing the point of view of Western feminists." 250

To use the terms of Pour une morale de l'ambiguïté, the trip was undertaken in response to the "appel" (call or appeal) from others for political solidarity.

249 Simone de Beauvoir, "Speech." The translation, by Marybeth Timmerman, later appeared as part of "Short Feminist Texts from the Seventies and Eighties" in the Feminist Writings volume of the Beauvoir Series. Introducing the piece there, Françoise Picq notes: "In March of 1979, women who had participated in the demonstrations against the Shah's regime and contributed to his fall, once again took to the streets of Tehran for five consecutive days. They were protesting against the obligatory veil. Attacked by counterdemonstrators, they were accused of playing into the hands of counterrevolutionaries and being manipulated by foreign agents. International feminist solidarity had to be shown, in spite of hesitations from the Left. On March 16, a demonstration was organized in Paris with the slogans, 'No Shah, no chador, no Russian tanks,' 'the Right veils women, the Left veils its eyes,' and 'Sails/veils unfurled ... toward terror?'” Translator Marybeth Timmerman explains the plays on words: "When spoken in French, the words for 'shah, 'chador,' and 'tanks' in the first slogan all sound similar: 'Ni shah, ni chador, ni chars russes.' The second slogan, 'La droite voile les femmes, la gauche se voile la face,' uses the expression 'se voiler la face' to mean "look the other way.' The last slogan plays on the words 'le voile' (veil) and 'la voile' (sail): 'à toutes voiles' (meaning 'full speed ahead under full sail') also sounds like 'veils for all women"'(238).

See also Simine Nouri, "Face à une misogynie hors du temps." Beauvoir's texts circulated on the black market after being banned by the Mullahs, and influenced Maryam Radjavi, leader of an exiled Iranian resistance group.

Vintges, "Surpassing Liberal Feminism," 20. 
But debates about how best to do this seemed to pale in the light of facts on the ground: the Iranian feminist resistance was utterly crushed in a matter of days. Alice Schwarzer, who went to Iran with the European delegation, remembered that her group was invited to meet with the Ayatollah on condition that they wear the chador. This led to a furious and seemingly interminable debate among the members of the delegation, which Schwarzer resolved by telephoning Beauvoir in Paris; as Schwarzer told the story, Beauvoir listened to the whole thing and then said, "Enfin, c'est ridicule."251

Perhaps at a certain point "this is ridiculous" becomes the only possible response? That's the approach taken by a very strange, but rather wonderful, absurdist play, Madah-Sartre: The Kidnapping, Trial \& Conver(sat/s)ion of JeanPaul Sartre \& Simone de Beauvoir, written (from exile) in 1995 by the Algerian playwright Alek Baylee Toumi, and translated into English by the author in 2007. The play's conceit is that Sartre and Beauvoir come back to life to attend the funeral of the Francophone Algerian writer, Tahar Djaout, who in real life was murdered in 1993 by the Groupe Islamique Armé (GIA). In Toumi's play, the existentialist couple is kidnapped on the way to Djaout's funeral by Islamist militants, whose leader "Madah" demands that they convert to Islam or be killed. ${ }^{252}$ Sartre debates with Madah, giving voice to what seem to be the playwright's own views on politics, violence, atheism, foreign debt, the similarity between Madah and Le Pen, the hypocrisy of rape and violence in the name of Islam, the hijacking of the Algerian elections, and more; meanwhile Beauvoir, segregated with the "chadorettes" and accused by their "Chief Chador" of being the "master thinker of our homegrown feminists," interrogates those who are

251 Presentation at the 2008 conference; no written version of this informal intervention appears to exist.

252 In his introduction to the English version, James LeSueur explains that this character's name is short for Mad-d-Allah, "to symbolize Islamic fundamentalists," and that he is partly based on Anwar Haddam, a leader of the Islamic front (xiv). Madah's name and Toumi's title also riff on Peter Weiss's musical play, Marat-Sade, The Persecution and Assassination of Jean-Paul Marat as Performed by the Inmates of the Asylum of Charenton Under the Direction of the Marquis de Sade, and Toumi, who is also a literary scholar, makes numerous other references to twentieth-century French literature, here and in his other works. 
attempting to interrogate her and accuses her accusers of being "parrots" and of betraying the Algerian revolution. ${ }^{253}$

Madah/Sartre is deliberately anachronistic, to put it mildly, in that it shows Beauvoir and Sartre as aware of events that took place after they died. It demands to be read through its own historical moment: a violent power struggle between Islamist militants attempting to impose sharia, and the FLN government, socialist in name but violently repressive; there were daily attacks on intellectuals and artists-Djaout was one of many killed or driven into exile around that time-and, meanwhile, the poor of Algeria were ground between two millstones. ${ }^{254}$ Toumi intercuts the debate scenes with a narrative featuring an ordinary Algerian man, a desperately impoverished taxi driver, who endures two unprovoked (and identical) attacks, one by the police and the other by Islamic militants, and then searches futilely for medical help in a corrupt and impoverished hospital system: seeking thread to have his wounds stitched closed, he is sent to the morgue, where limbs and heads are being sewn back on dismembered corpses.... While the taxi driver disappears at the end of act six on a note of despair, for himself and for his country, act seven concludes the play with a hopeful fantasy. Oddly enough, the atheist Sartre admits that there is a heaven - he has, after all, just come from there. But it is a multicultural heaven where atheists are accepted, people are judged based on their earthly deeds, and God (much to Madah's despair) turns out to be a woman. Beauvoir meanwhile convinces the chadorettes to use their veils as sails and fly away, and the play ends with a Berber dance and a song to "the Freewoman" and the female God.

As a reader, I admit to finding the ending less compelling than the debate, ${ }^{255}$ where (among many other things) Toumi (through "Sartre") defends the right of Algerian intellectuals to be considered on their own terms, not as Westernized dupes. ${ }^{256}$ And while Beauvoir is not afraid to lecture the chadorettes, she too does so mainly with reference to Algerian precedents.

253 Madah/Sartre, 58, 66.

254 Toumi introduces the English version with a "warning" against confusing "Islamism" and Muslim peoples- "The victims are Muslims, while the killers, the assassins, the terrorists are Islamists" (xx). James LeSueur's introduction does a fine job of supplying historical details.

255 The reverse might well be true in performance-it's difficult to judge.

256 "Madah: If we have Francophone intellectuals, it is because of you. They imitate you.

Sartre: You're wrong again. If I am like this, it is thanks to one of your early ancestors. One of the great intellectuals of the world is Algerian. Born in Hippo-Annaba, thousands of years ago, the early Christian bishop Saint Augustine spoke Berber, was Berber, and wrote in Latin. We still have his Confessions. After him, there was Averroës in Spain, father of secularism ... he was Muslim! And many others that you don't know. Today there is 
You are a bunch of parrots. There are Algerian women who have been assassinated because they refused to wear it. Some were kidnapped and raped. Just out of respect for women like Kheira, who have been gangraped, or Katia, who was gunned down because she stood up, you should remove it. ${ }^{257}$

She rips up the veil they have given her, saying, "This is what an Italian woman did in front of the Ayatollah!"258 But she also argues that the Koran does not require the veil- "No. Isn't it said that she must 'cover' herself? Clothes are enough"259 — and that the chador is not Algerian but an imported badge of "international fundamentalism." "Why don't you wear the traditional white haik, the veil of Algerian women?"260

Chief Chador: Feminist propaganda. That's the work of Kahina. Not only has she read your books, but now it is you who read hers.... Unbowed! She escaped twice ... next time, she'll pay for it. ${ }^{261}$

"Kahina" is Toumi's name for Algerian feminist Khalida Messaoudi, whose book is called Unbowed: An Algerian Woman Confronts Islamic Fundamentalism. Like Sartre, Beauvoir is not afraid to call out the hypocrisy of claims to "piety" - "How many of you wear a mini skirt and a diaphragm under the chador?"- and in the end she says to the chadorettes, "Go see The Battle of Algiers. You don't even know your own history."262

Kateb, Mammeri, Djaout, Mimouni....They are agnostics, atheists, secular Muslims but all tolerant." Madah/Sartre, 94.

It's a stretch for me to imagine Sartre defending St. Augustine, or taking him as an intellectual ancestor. Perhaps he met Augustine in heaven and changed his mind? Sartre did, sometimes, change his mind ... or perhaps he was thinking of the influence of Augustine's Confessions on Les mots. Toumi is anyhow on firmer ground when he assumes that Sartre and Beauvoir would have continued to read the works of Kateb Yacine, who is mentioned in Beauvoir's memoirs as a good friend.

257 Madah/Sartre, 63-4

258 Ibid., 70.

259 Ibid., 63.

260 Ibid., 65 .

261 Ibid., 66. Messaoudi's book describes death threats, and living under fatwa, but is also critical of American government interventions in the region. An opponent to the unequal "family code," Messaoudi has since joined the Algerian government and served as Minister of Culture. The name "Kahina" originally belonged (Wikipedia tells me) to a "seventh century female Berber religious and military leader, who led indigenous resistance to Arab expansion in Northwest Africa."

262 Ibid., 66, 67. 
"Tell me who you haunt and I will tell you who you are"?263 No, this is crazy. Ghosts can't offer evidence. And "Beauvoir's" statements about the veil in Toumi's play go far beyond anything Beauvoir herself actually said about it: the questions she answers in the play are not the same ones that arose in her lifetime. But it is hardly Toumi's project to give an accurate account of what Sartre and Beauvoir believed and did "in real life." (In fact, he gets some small biographical details wrong.) His project is to tell the world that Algerian feminism, and an Algerian nationalism that respects multiculturalism and human rights, are alive and well; ${ }^{264}$ and secondarily, to explore the relation between the culture of France and her former colonies in a more nuanced and multi-directional way than is permitted by post-colonial orthodoxies, whether of the Left or the Right. But his reading of existentialism's legacy is a plausible one, and I include it here as part of my project to look, not just at what lay upstream from existentialist arguments, but also at what lay downstream, what could come of those arguments later. Perhaps Toumi's play suggests that incompatible goods (or, here, competing evils) need not paralyze us.

Without myself endorsing any position, I want to spend a little more time exploring and historicizing what can motivate a view like Toumi's. Around the time Badinter and Kristeva were awarding the Beauvoir prize to Hirsi Ali, Algerian feminist Marnia Lazreg wrote a book called Questioning the Veil: Open Letters to Muslim Women which made arguments rather similar to those Beauvoir's ghost offers in Toumi's play. Lazreg has no love for French attempts to ban the veil, or for Turkish ones either; but her analysis asks younger women, who are taking up the veil as a signifier of religious commitment or nationalist pride, to think about what they are doing, to see how it connects to a larger social and historical picture, and to remember the generation of women from Muslim cultures who discarded their veils in order, she says, to "seize their place in the human universe." ${ }^{265}$ She begins by explaining her own standpoint, making it clear that she is no Hirsi Ali.

In my previously published work, I have consistently objected to the manner in which Muslim women have been portrayed in books as well as the media.... [T] hey have been represented as oppressed by their religion, typically understood as being inimical to women's social progress.... [and] have been described as the weakest link in Muslim societies....

263 One way of translating the opening line of André Breton's Nadja.

264 Another thread in "Sartre's" argument has to do with the problem of imposing classical Arabic as a "standard" on the Berber minority, to which Toumi belongs.

265 Lazreg, Questioning the Veil: Open Letters to Muslim Women, 2009, 50. 
Such a view made it acceptable to hail the war launched against Afghanistan in 2001 as a war of "liberation" of women.... In this context, any Muslim woman who takes cheap shots at Islam and crudely indicts Muslim cultures is perceived as speaking the truth and is elevated to stardom. ${ }^{266}$

Nonetheless, feeling that she "can no longer keep quiet," she asks Muslim women to consider the ways that veiling - even where freely chosen - can be harmful to women who do it, whether they think so or not; and she also argues that Muslim women in France or the US who choose to "re-veil" show a failure of solidarity with women in Iran and Saudi Arabia where the veil, and other restrictions on women's free movement and full participation, are imposed with severe and sometimes violent sanctions. She respects arguments based on religious conviction, particularly when a woman has been convinced by her own study of religious texts, rather than by social pressure, or the preference of a father, brother, employer, or prospective husband, or as a matter of "strategy." "Nevertheless," she writes,

[I]t is crucial that any woman who decides to wear any type of veil examine her conscience and determine whether the veil is the only manner for her to fulfill her spiritual needs. Because of both its role in the history of women's exclusion from social life outside the home and its resilience, the veil is overlaid with meanings that cannot simply be brushed away because a woman says so. Whenever a woman wears a veil, her act involves other women, including the girl child. ${ }^{267}$

For Lazreg, the meaning of the veil is always social, and historical, not just an individual "choice"; 268 the veil, wherever it is worn, is about masculinity, male

266 Ibid., 1. See also 6o- -Banning the veil is as much a political act as is mandating it.... Women are held hostage equally by radical secularists and Wahabists, Islamists and Shi'i Muslims. None of them trusts women with the capacity to decide for themselves how to manage their bodies and whether to wear a veil. None of them has asked women for their opinion in the matter."

267 Ibid., 11.

268 Ibid., 36. See also 128: "When a woman wears it, she garbles its meanings insofar as she never knows which one of these will be perceived by others as the one that she has attributed to it. Ironically, as a woman thinks that she is making a clear statement by wearing a veil, she loses control over its meaning. Yet she assumes all the meanings that have been historically associated with it."

There's a larger "theory of meaning" question here that is not geographically or culturally specific. Consider the survival in the USA of wedding rings (once marks of possession) or the custom of the bride being "given away" by her father. Is the social and historical 
dominance. "The veil is a man's affair before it becomes a woman's." "A man's absorption in the details of a woman's relation to her body is an assault on her dignity." "It is difficult to extirpate the veil from the thick history of men's power."269

Lazreg never mentions Beauvoir by name, but she describes her own approach as an "an existential-philosophical standpoint that peels away the justifications that women who wear it or intend to wear it usually invoke."270 She provides compelling phenomenological accounts rooted in her own experience; she also introduces and interprets stories about other women from various places and generations, in a way that feels similar to The Second Sex's investigation of "lived experience" by the method Patricia Moynagh characterized as "exemplary validity." Also like Beauvoir, Lazreg does not shrink from reinterpreting what she hears.

Over the past fifteen years, I have spoken with and interviewed numerous women, old and young, in the Middle East, North Africa, France, and the United States who have worn one type of veil or another; women who took off their veil but felt they have to put it back on; and women who have been thinking of wearing one. I take these women's arguments seriously but wish to subject them to scrutiny as I am convinced that only rational reflection can advance women's understanding of themselves, particularly in times of political turmoil. ${ }^{271}$

She excavates a number of arguments that she regards as "rationalizations,"272 and notes that the strongest male advocates of the veil (in Algeria, in Iran) have done nothing to protest violent attacks against women.

meaning of these ancient customs erased because an individual woman says so? Why do these demeaning reminders of women's subordination survive? Are they "resignified" in a subversive manner when applied symmetrically to both partners? Or when the partners are both women? Or do they simply take the edge off any potential threat to compulsory heterosexuality? "Oh, no one in the US would raise those questions." But I just did.

269 Ibid., 57, 121, 1.

270 Ibid., 1.

271 Ibid., 11.

272 These include the idea of the veil as "protection" or "shield" against sexual harassment. Lazreg points out that "in practice, harm comes from men to women no matter whether they are practicing, veiled, or not"; what the veil "protects" is male identity and masculine privilege (ibid.,43). "If a woman's veil is a symbol of modesty that protects her from sexual harassment, why do men not show modesty in their behavior toward women by refraining from harassing them?" Ibid., $5^{2}$. 
Lazreg is particularly critical of theoretical arguments that the decision of younger women to veil must be respected in the name of "agency."

This is a delicate endeavor as the risk is great that a woman's rationale for wearing a veil might be discounted as a form of false consciousness, and her agency dismissed as illusory. As a social scientist, I cannot deny women's agency or substitute mine for theirs on the grounds that I am more equipped to make sense of their motivations than they are.... However, agency is not a free-floating capacity independent of the social framework within which it expresses itself; neither is it above questioning. ${ }^{273}$

In other words, while the question of agency is an important one, it is not reducible to how an individual woman feels. ${ }^{274}$ Plus, there is a remainder in the form of ethical and political questioning: Agency for what? Agency on behalf of what? In solidarity with whom? "Agency must be distinguished from consciousness - the capacity to see through the myriad contingencies that determine the 'choice' that a woman makes for the good."275 The agency Lazreg is taking up here for herself, then, is a kind of intellectual agency: the right to draw conclusions, to make judgments.

Beauvoir, as we have seen, never seems to have questioned her right to describe other women's self-understandings, however sincerely held, as complicit mystifications. (Insofar as women might have recognized themselves in the unflattering portraits she drew, this was supposed to induce them/us to change. ${ }^{276}$ But Lazreg is well-aware of subsequent feminist critiques that emphasize women's "agency," and she confronts those critiques head-on, naming a number of feminist works, the best-known to non-specialists probably being Saba Mahmood's Politics of Piety: The Islamic Revival and the Feminist Subject. ${ }^{277}$ Lazreg writes:

The reveiling trend coincides with an approach espoused by academic feminists that seeks to correct the notion that the veil is a sign of "oppression" but in reality makes oppression more intellectually acceptable. Although acknowledging that veiling may reinforce gender inequality, this approach uncritically and unapologetically foregrounds lower-middleclass women's stated reasons for taking up veiling. Its proponents engage

\footnotetext{
273 Ibid., 9 .

274 Also, the question of power is not reducible to the question of (individual) agency.

275 Ibid., 74.

276 I say "us" advisedly; it is women of her own race and class background who come in for her scorn in volume 2 .

277 Ibid., 75 .
} 
in various degrees of sophisticated theoretical hairsplitting in order to excavate the operative agency assumed to be lurking behind the veil, subverting its use, and turning it into a tool of empowerment. The implication is that the "oppressed" are not so oppressed after all; they have power. Faced with this newly discovered power frontier, the researcher does no more than study its manifestations. ${ }^{278}$

Questions of meaning and agency also connect to questions of "authenticity" and authority: which women do we listen to, and why?

In bending over backward to "give women a voice," adherents to this approach find it necessary to dismiss the reality of women who object to veiling. ${ }^{279}$

There's something deeply insulting about this. "The referent Westernization implies that a woman cannot think of change outside of a Western frame of reference." 280

Now, others have made this general point before. Lila Abu-Lughod (author of "Do Muslim Women Really Need Saving?") has even mobilized Edward Said's work to do so.

Following one of the most productive lines of thought made possible by Orientalism, with the division between East and West (and representation of each) to be understood not as a natural geographic or cultural fact but as a product of the political and historical encounter of imperialism, we argued that condemning "feminism" as an inauthentic Western import is just as inaccurate as celebrating it as a local or indigenous project. The first position assumes such a thing as cultural purity; the second underestimates the formative power of colonialism in the development of the region. ${ }^{281}$

278 Ibid., 5 .

279 Ibid. The conclusion restates this even more forcefully: "The veil has been tantalizing to Muslims and non-Muslims, including intellectuals. Attempts to present it as a tool of empowerment of women rest on a dubious postmodern conception of power according to which whatever a woman undertakes to do is liberating as long as she thinks that she is engaged in some form of 'resistance' or self-assertion, no matter how misguided.... (ibid., 125-26).

280 Ibid., 114.

281 Lila Abu-Lughod, "Review essay: 'Orientalism' and Middle East Feminist Studies," 106. Written for the twentieth anniversary of Said's book, Abu-Lughod's piece reflects on its productivity for feminist thinking, beyond what its author originally envisioned. "We" 
What makes Lazreg's account particularly apposite to my point here is the historical cast of her argument.

We seldom ask ourselves how the generations of women who wore veils felt about them. We cannot imagine them without their veils, as if they had been born with them; we expect them to wear them because they expected to wear them. Yet they experienced a more limited existence because of their veils. ${ }^{282}$

And many women from the generation of Lazreg's mother made lucid and deliberate choices to stop wearing veils, in their own interests and the interests of their daughters. In her concluding summary, "Why Women Should Not Wear the Veil," the first item Lazreg lists is "the need to recapture the historic role that women have played as agents of change."283 Now, Lazreg's book is addressed to her Muslim sisters, and not to women like me-the word "letters" in her subtitle makes that crystal-clear-and I want to avoid any impression that I think I have the right to judge this question on their behalf. But if she's right that "the academic sanctioning of the veil turns it into a fixture of the Muslim landscape rather than an evolving phenomenon," ${ }^{284}$ then as an academic feminist I do have some standing, and indeed some obligation, to consider what my position and approach should be.

Like Toumi, Lazreg is saying to the young women who take up the veil their mothers rejected, "you do not know your own history." The particular value of Lazreg's book for my own investigation is that it reminds us to hear the voices Beauvoir heard on her visit to Tunisia, the urban women she met at the house of Mr. and Mrs. E. while she was there, whom she described as "thirsty for freedom" (right before the passage where she shows her sympathy for the wives in the dark cave). ${ }^{285}$ In real life, Beauvoir's positions were very much informed by the testimony and activism of an older generation of feminists from the Arab world; Lazreg's discussion reminds us why she might have heard these

here refers to a collection of essays she edited, Remaking Women: Femininity and Modernity in the Middle East.

282 Lazreg, Questioning the Veil, 17.

283 Ibid., 97. The other reasons include "doing away with the physical and psychological effects of veiling; awareness of the effect of the veil in the workplace; and demystifying propaganda that portrays women's desire for progress as mimicry of the 'West' and thus an offense to their culture and religion."

284 Ibid., 6.

285 FCh 1:83-4, FCirc 64. 
"évoluées," as they would then have been called, as authentic and legitimate voices, and trusted what they told her.

Among "us" "now," this historicizing view is less well-known than Saba Mahmood's critique of feminism's "normative secularism" in The Politics of Piety, which many people teach as a groundbreaking text of feminist theory and an important corrective to the ethnocentrism that plagues US views of Islam and the Middle East. Karen Vintges, who likes the book, describes it as a

critique of Western feminism's too narrow models of self and society ... based on [Mahmood's] study of a grassroots women's piety movement in Cairo. The women participating in this Islamist movement, instead of being the oppressed creatures that Western feminists hold them to be, are religious agents who practice an ethical "self-cultivation" that engages their entire way of life. Liberal feminists with their "conceptions of the subject, autonomous reason, and objectivity, though which the pietists are understood to be lacking in faculties of criticism and reason" cannot imagine that Muslim women strive for completely different values: namely, a pious instead of a free, autonomous life. ${ }^{286}$

Mahmood herself, though, did not entirely envision this reading. In her preface to the 2012 edition, she wrote:

Since its publication, Politics of Piety has elicited both the praise and the ire of feminists: some have hailed the book for restoring agency to religiously devout Muslim women hitherto denounced for their patriarchal proclivities. Others have condemned the book for precisely the same reason: insofar as the book is read as an exposé of the "agency" of the women who constitute the piety movement, it is charged with leveling critical differences between women who are upholders of patriarchal norms (dangerous, supine, submissive) and those who fight these norms in the name of liberty and freedom (heroic subjects of history). Both these readings ignore the fact that I was not interested in delivering judgments on what counts as a feminist versus an antifeminist practice, to distinguish a subversive act from a non-subversive one. While acts of resistance to relations of domination constitute one modality of action, they certainly do not exhaust the field of human action. Rather, the aim of this book is to

286 Vintges, A New Dawn for The Second Sex, 62-3, quoting Mahmood, Politics of Piety, xii. 
develop an analytical language for thinking about modalities of agency that exceed liberatory projects (feminist, leftist, or liberal). ${ }^{287}$

So on some level, she sees both Vintges and Lazreg as missing her point.

Taken on its own terms, Mahmood's is unquestionably a brilliant book. She is certainly right that identity politics will not help us understand the dynamics of the piety movement, or much else. Her conclusion is especially powerful: she does not want to think along the logic that led to a "feminist" war on the Taliban, or to participate in the liberal discourse that has done even broader harms, in the colonial period and afterward. But what is the alternative? "By allowing theoretical inquiry some immunity from the requirements of strategic political action, we leave open the possibility that the task of thinking may proceed in directions not dictated by the logic and pace of immediate political events." 288

In other words, we can think better (more clearly, more creatively) by bracketing what is actually (Beauvoir would say, "concretely") at stake. And I'm sure Mahmood is right. My question is whether thinking clearly and creatively is the (whole) point, or whether feminist thinking (as opposed to other sorts of good thinking) was supposed to engage with what's concretely at stake. The fact that I can't for the life of me come up with a more "up-to-date" verb than engage illustrates how fully irreconcilable these two philosophical positions are, even before one takes up the particular disputes about Islam, secularism, and the veil.

Let me try to clarify this by looking at one of Mahmood's examples, her analysis of two perspectives on the difficulties of life as a single woman in Egypt and of the role played by "șabr," which is not just a virtue but a practice, something she describes, following Foucault, as an ethical "technique of the self." Mahmood explains, "I have retained the use of șabr in this discussion rather than its common English translation, 'patience,' because șabr communicates a sense not quite captured by the latter: one of perseverance, endurance of hardship without complaint, and steadfastness." In the example-story, a woman called Nadia, who participates in the piety movement, uses the language of sabr in attempting to persuade her friend Sana to accept an offer of marriage from a man Sana does not much like, who already has a wife. Sana, a liberal Muslim, disagrees: she feels șabr encourages one to be passive, and prefers a virtue (or, if you like, a practice) she labels "self-esteem." Sana says,

287 Mahmood, Politics of Piety, $\mathrm{x}$.

288 Ibid., 196. Mahmood references Wendy Brown's Politics Out of History here. 
Self-esteem makes you independent of what other people think of you. You begin to think of your worth not in terms of marriage and men, but in terms of who you really are, and in my case, I draw pride from my work and that I am good at it. Where does șabr get you? Instead of helping you to improve your situation, it just leads you to accept it as fate-passively.

Mahmood glosses their disagreement as follows:

Neither [Nadia] nor Sana, for a variety of reasons, could pursue the project of reforming the oppressive situation they were forced to inhabit. The exercise of șabr did not hinder Nadia from embarking on a project of social reform any more than the practice of self-esteem enabled Sana to do so. One should not, therefore, draw unwarranted conclusions between a secular orientation and the ability to transform conditions of social injustice. Further, it is important to point out that to analyze people's actions in terms of realized or frustrated attempts at social transformation is necessarily to reduce the heterogeneity of life to the rather flat narrative of succumbing to or resisting relations of domination. Just as our own lives don't fit neatly into such a paradigm, neither should we apply such a reduction to the lives of women like Nadia and Sana, or to movements of moral reform such as the one discussed here.

At this, my heart rose (to borrow Anne Bradstreet's phrase). Yes, Mahmood is right, I thought: her book has nothing at all to say about feminist questions. Because what about Sana? I completely accept Mahmood's argument that always looking for "resistance" to (or "resignification" or "subversion" of) the norm is often an oversimplification and an annoying tic. But her suggestion here is that we are wrong to ask the question, even when that question is explicitly framed as such by the subjects themselves. ${ }^{289}$ If the ethical and methodological imperative is to "listen to the women," shouldn't we listen to both of them? ${ }^{290}$ Moreover, the failure of any movement for "social reform," or at least

289 Mahmood tries to avoid describing the women she discusses as "informants," or labelling what they say as "data," in an attempt to avoid a patronizing ethnographic gaze; I appreciate her reasoning, but I still can't find a better word than "subjects": there remains a nonreversible relationship between the researcher and those she is writing about.

290 Isn't Sana's practice of "self-esteem" also an ethical technique of the self? just like Nadia's, it embeds a vision of an underlying system of right and wrong, and a transpersonal salvific goal, whether or not Sana as an individual will reach that goal. (Notice that in describing it, she says "you," rather than "I," which sketches a further step toward "we," though she does not quite take that step.) 
the impossibility of either of these women participating in such a movement, is here taken as a given in advance. Why? As Lazreg would point out, history shows that such things do happen, have happened, could yet happen.

So the argument here is not really between Nadia and "Western feminists," it is between Nadia and Sana. (And since both of them are Egyptian, and both are Muslim, can I really be giving ground to Islamophobia when I find one response preferable, and the other, certainly understandable, but rather sad?) Nadia's faith practices not only help her cope with the less than ideal features of her own situation, but lead her to try to talk her friend into a disadvantageous marriage the friend lucidly does not want, simply because Sana is getting older, this is the only offer she is likely to have, and life as an unmarried woman is (they both agree) quite difficult. I completely accept the legitimate agentic rationality of both positions here. The problem is on a different level.

And indeed, there is nothing peculiar to Islam about the agency and energy with which the women in the da'wa movements enact their self-subjection and help enforce the subjection of other women, nor about the interpretive dilemma this proposes for feminism. In the American Midwest, one can tune in to Christian radio and hear, at almost any hour, "women's Bible study programs," led by women for women, which do very much the same thing as the Egyptian da'wa leaders and groups Mahmood describes, although the particular texts preaching women's submissiveness to husbands and church authorities are drawn from a different holy book. (When the daughters of these evangelical women turn up in my classes-and they do-surely I should have something more to offer them than the equivalent of "well, Nadia has a point, too"?) ${ }^{291}$

Mahmood herself, in her brilliant description of the process of "subjectification" (rooted in Foucault), often draws cross-cultural parallels: her book does not make a case based on cultural difference, not at all. But I am not sure that her dichotomy between "secular" vs "religious" motivations exactly names what's at stake here, either. Mahmood says in the passage I quoted above that we "should not ... draw unwarranted conclusions between a secular orientation and the ability to transform conditions of social injustice." But do feminists really draw such conclusions? The more I think about this, the more it strikes me as a red herring. We all know that without religious motivation there would have been no Gandhi and no Martin Luther King (and no Anna Julia Cooper). As I write, the rightness or wrongness of Trump's gulag for migrant

291 Feminist pedagogy asks us to be careful not to judge women's choices. But instead, we judge one another for doing so. I wish I knew who authored the brilliant meme which captures this: "I could tell the minute I saw her how effing judgmental she was." 
children is, bizarrely enough, being argued out in the public sphere through competing interpretations of the Bible; some "mainline Protestant" folks are putting themselves to the trouble of trying to get the Methodist church to expel Attorney General Jeff Sessions for citing the wrong chapter and verse and thereby misrepresenting "what Jesus would do"; meanwhile clergy from all denominations are lining up to be arrested, just as they did during the Vietnam war, and even the nuns on the bus are up in arms....

You know, if America has a secular culture, I certainly have never succeeded in finding it. (Ask a Jew.) Mahmood's work after The Politics of Piety was devoted to showing that "the secular" is pretty much a mirage, an argument I find compelling. Then too, when feminism of any stripe enjoys widespread collective success, it undoubtedly employs practices and techniques of the self, such as consciousness raising, group exegesis (what else are you and I doing right now?), revival meetings (Take Back the Night), the adoption of particular watchwords and, yes, articles of clothing. ${ }^{292}$ It would make more sense to me to say we should accord to Islamic feminisms the same respect we accord to Christian feminisms, and no less; and possibly, that we should accord to Islamist anti-feminist women the same respect we accord to Christian evangelical anti-feminist women, and no more.

Now, when a practitioner of Mahmood's sort of critique is asked, "what then would a better feminist praxis look like?" they may respond that answering that question is not their project, and that is fair enough. ${ }^{293}$ But when one does want to do some feminist work in/on the world we live in, one then falls back, either on one's gut, or on an older theory. ${ }^{294}$

292 Why can't we recognize feminist ethics as a technique of the self? And as a recognition of the social and communal rather than the individual? It does not often succeed, for reasons Beauvoir explained, but that vision is always there, even in the most "lean in" of places.

293 Why then is this book so important to (American) transnational feminist theory? Perhaps (through no fault of Mahmood's) because it supports the individualist self-actualization story parodied by The Onion: "It's official: women now empowered by anything a woman ever does." Perhaps it also meshes well with our custom that matters of religious conviction must be seen as beyond debate. Whether this is because we are a secular country, or because we are secretly still a theocracy, I leave you and history to decide.

294 Even Judith Butler now walks under the banner of human rights, because she has come to care about Palestine, and feels some particular responsibility as a Jew. Is there some version here of the "there are no atheists in foxholes" thing? There are no posthumanists in detention camps? There probably are, though, or will be. Your theory will not protect you ... just as no one's aesthetic or philosophical commitments predicted what they did when the Occupation came, in either direction. 


\section{Last Thoughts}

Where I'm going with this is that the "existentialist perspective" Lazreg shares with Beauvoir makes it possible to see certain things that Mahmood's approach leaves in shadow. Nadia and Sana share a social location; they are both intelligent and rational; they do not differ in their understanding of the situation of single women in Egyptian society, nor do they differ in finding it a bad situation. They simply disagree about what Sana should $d o$. What we see here is that when people from the same cultural backgrounds are faced with the same oppressive conditions, some people struggle against those conditions as best they can. Other people find reasons to give up. ${ }^{295}$

And actually, I think Mahmood herself fails to notice a form of "rational agency" that would have been all too clear to Beauvoir, who recognized women's agency in many forms of action by women, not just "resistance to norms." Here that recognition would have taken the form of understanding that Nadia did have choices, including the choice not to betray her friend. Full human agency involves the ability to do harm.

Am I channeling Beauvoir's ghost here? Maybe, and that's weird, yes. But the argument between Nadia and Sana maps rather well onto the argument between Simone and her close friend Zaza that shapes the ending of Mémoires d'une jeune fille rangée. Zaza's mother wanted her to make an arranged marriage, rather than an "unsuitable" love match; Zaza's reading of Claudel (that same Claudel) and of other Catholic writers was convincing her that submission to her mother's bourgeois values was required as a religious duty, and that her abjection was beautifully pleasing to God; and Beauvoir, raised in the same milieu, was like, I know you love your mother, and I respect your view, but, no. No. Just, no.

Harking back to the time, and the language, of the "évolués," Lazreg's book takes as epigraph a quotation from Aimé Césaire's Discourse on Colonialism, though she inserts "women" where he had "men":

We are not [wo]men for whom it is a question of "either-or." For us, the problem is not to make a utopian and sterile attempt to repeat the past, but go beyond it. 296

295 Years ago, when I first started teaching feminist theory, a student asked me, "what makes people different?" (She was thinking of her sister, who was happily conforming to a set of norms for women she herself found unbearably oppressive.) I don't know, I said, feeling (then) like a bit of a failure for not knowing; and I've gone on worrying about it. But maybe "I don't know" is actually a good answer, and there is something to be said for the irreducible singularity of each human being.

296 Lazreg, Questioning the Veil, iv. 
Still, if taken seriously this familiar idea of "dépassement" can cut more than one way. Because the women in France who embrace the veil as a sign of a new Islamic modernity might respond to Lazreg: yes, exactly; why should we be bound by your mother's interpretation of the veil? That was a new day for her, and today is a new day for us. (In the US, the first hijab-wearing woman was just hired to read the news on network TV. In a context of daily public attacks, some of them violent, against anyone who "looks Muslim," surely this reads as a victory?) Once again, there are no recipes, and context is all.

So maybe if Beauvoir came back from the dead, what she'd have to say (to be perfectly consistent) would be, wait, what can you tell me about what is actually going on there now? 